UNIVERSIDADE DE SÃO PAULO

FACULDADE DE ECONOMIA, ADMINISTRAÇÃO E CONTABILIDADE DEPARTAMENTO DE ADMINISTRAÇÃO PROGRAMA DE PÓS-GRADUAÇÃO EM ADMINISTRAÇÃO

\title{
A QUESTÃO DOS RISCOS EM AMBIENTES DE COMPUTAÇÃO EM NUVEM
}

Sidney Chaves

Orientador: Prof. Dr. Cesar Alexandre de Souza

\author{
Versão Corrigida \\ (versão original disponível na Unidade que aloja o Programa)
}

SÃO PAULO 
Prof. Dr. João Grandino Rodas

Reitor da Universidade de São Paulo

Prof. Dr. Reinaldo Guerreiro

Diretor da Faculdade de Economia, Administração e Contabilidade

Prof. Dr. Adalberto Américo Fischmann

Chefe do Departamento de Administração

Prof. Dr. Lindolfo Galvão de Albuquerque

Coordenador do Programa de Pós-Graduação em Administração 


\section{A QUESTÃO DOS RISCOS EM AMBIENTES DE COMPUTAÇÃO EM NUVEM}

Dissertação apresentada ao Departamento de Administração da Faculdade de Economia, Administração e Contabilidade da Universidade de São Paulo, como requisito para a obtenção do título de Mestre em Administração.

Orientador: Prof. Dr. Cesar Alexandre de Souza

\section{Versão Corrigida}

(versão original disponível na Unidade que aloja o Programa)

\section{SÃO PAULO}


Dissertação defendida e aprovada no Departamento de Administração da Faculdade de Economia, Administração e Contabilidade da Universidade de São Paulo - Programa de Pós-Graduação em Administração, pela seguinte banca examinadora: Prof. Dr. Cesar Alexandre de Souza, Prof. Dr. Hiroo Takaoka e Prof. Dr. Manoel Veras Souza Neto.

\section{FICHA CATALOGRÁFICA}

Elaborada pela Seção de Processamento Técnico do SBD/FEA/USP

\section{Chaves, Sidney}

A questão dos riscos em ambientes de computação em nuvem /

Sidney Chaves. -- São Paulo, 2011.

$150 \mathrm{p}$.

Dissertação (Mestrado) - Universidade de São Paulo, 2011.

Orientador: Cesar Alexandre de Souza.

1. Tecnologia da informação 2. Computação em nuvem 3. Administração de risco 4. Técnica Delphi I. Universidade de São Paulo. Faculdade de Economia, Administração e Contabilidade II. Título.

CDD -658.4038 
Para Mônica, querida companheira de todos os momentos, cuja compreensão e incentivo foram mais do que decisivos para que este trabalho pudesse ser realizado. 


\section{Agradecimentos}

Meu sincero agradecimento, em primeiro lugar, ao Prof. Dr. Cesar Alexandre de Souza, orientador deste trabalho, pela oportuna sugestão do tema e pelas intervenções sempre precisas e didáticas ao longo dos prolongados meses durante os quais este estudo se desenvolveu.

Agradeço também ao Prof. Dr. Hiroo Takaoka, pela valiosa contribuição quando da participação na banca do exame de qualificação, com intervenções e sugestões que, tenho certeza, fizeram por melhorar enormemente a qualidade deste trabalho.

Meu agradecimento, ainda, aos demais professores das disciplinas que cursei ao longo do Programa de Mestrado, cujos ensinamentos em muito contribuíram para que mais esta etapa da minha história acadêmica pudesse ser cumprida.

Da mesma forma, agradeço à Lícia Abe, pelo incessante apoio, pela infindável paciência e, sempre atenta, pelas inúmeras dicas e sugestões de textos e eventos sobre computação em nuvem.

Como não poderia deixar de ser, meus agradecimentos aos participantes do painel Delphi que propiciou a obtenção das informações que viabilizaram este estudo - aos executivos de tecnologia da informação, cujos nomes devo, por compromisso, manter em anonimato e, especialmente, aos Profs. Drs. Antonio Carlos Gastaud Maçada, Jakow Grajew e Manoel Veras de Souza Neto.

Por fim, mas talvez em primeiro por importância, meu sincero e carinhoso obrigado à Mônica, minha esposa, e à Mariana, minha filha, por terem suportado minha ausência e pouca atenção enquanto estive envolvido com este estudo e por me terem retribuído com dedicação, incentivo e apoio incondicionais. 
"Nada é tão poderoso no mundo como uma ideia cuja oportunidade chegou." Victor Hugo 


\section{RESUMO}

Este documento apresenta e descreve o trabalho de pesquisa realizado com vistas a estabelecer recomendações destinadas a auxiliar consumidores de serviços de computação em nuvem a tratar a questão dos riscos inerentes a este ambiente, de modo tal a poder contratar serviços desta natureza com grau aceitável de risco. Para atender a este objetivo e aos demais objetivos secundários definidos, o estudo foi conduzido em cinco fases: revisão da literatura relativa à computação em nuvem, escolha e estruturação do método de pesquisa, aplicação do método de pesquisa, proposição das recomendações para o tratamento dos riscos e elaboração das conclusões. A revisão da literatura compreendeu um amplo levantamento bibliográfico sobre computação em nuvem, com ênfase na sua definição, nos modelos de referência e nos tópicos barreiras, benefícios e riscos. A escolha do método de pesquisa envolveu o processo de seleção do Delphi, acompanhado por outro extenso levantamento bibliográfico, desta feita sobre este método, e foi seguida da definição da sistemática a ser adotada para aplicá-lo especificamente nesta pesquisa; para aplicar o Delphi, foi escolhida a modalidade ranking form, por meio da qual se tornou possível determinar, após a realização de cinco rodadas do painel e contando com a participação de um grupo de especialistas formado por acadêmicos e profissionais de tecnologia da informação, rankings para as barreiras, os benefícios e os riscos associados à computação em nuvem. A partir do ranking dos riscos, foram estabelecidas as recomendações destinadas a satisfazer ao objetivo principal da pesquisa, que se traduzem, em linhas gerais, na indicação de quais riscos potenciais devem ser observados e tratados com maior grau de atenção pelas instituições, organizações e executivos de tecnologia da informação que pretendam dar seus primeiros passos no universo da computação em nuvem, bem como por aqueles que, já devidamente inseridos neste ambiente, queiram ou tenham a necessidade de rever conceitos e posições assumidos. Por fim, as conclusões e considerações finais contemplaram a análise dos resultados obtidos no painel Delphi relativamente às barreiras e aos benefícios. Como contribuição maior, este estudo oferece, acima de tudo, uma visão realista acerca da computação em nuvem e coloca à disposição daqueles que efetivamente por ela se interessam, por vontade própria ou dever de ofício, um rol de observações e recomendações úteis e oportunas.

Palavras-chave: Tecnologia da informação, Computação em nuvem, Administração de risco, Técnica Delphi. 


\begin{abstract}
This report presents and depicts the research carried out in order to find out recommendations that may possibly assist consumers of cloud computing services to deal with risks intrinsic to that architecture, so that consumers can be able to contract those kinds of services within an acceptable level of risk. The research comprised five phases to satisfy this main objective and also the secondary ones set up for it: review the literature related to cloud computing, choose and configure the research method, run the research method, find out the recommendations and make conclusions. The review of the literature consisted of an extensive bibliography research about cloud computing, putting emphasis on its definitions and reference models and on three other connected topics: barriers, benefits and risks. The choice of the research method encompassed the selection of the Delphi method seconded by another wide bibliography research, this time focused on the method itself, and was followed by the configuration of the Delphi method in order to get a script to be adopted to make properly use of the method in this research; to apply the Delphi method, it was chosen its "ranking form", that made possible, after five rounds and counting with the involvement of a group comprising academic people and information technology professionals, to establish rankings for barriers, benefits and risks, all related to cloud computing. Based on the ranking of risks, the recommendations destined to satisfy the research's main objective were thought up; in general, these recommendations can be viewed as indicatives of which potentials risks must be observed and treated in an upper attention level by institutions, organizations and information technology executives that intend to take their first steps toward cloud computing universe, as long as by those companies and people that, despite by now inserted in that architecture, want to or must review concepts and positions already took on. At last, conclusions and final considerations were written, both derived from the analysis of the results regarding barriers and benefits extracted from the Delphi panel. Above all, this study, as its major contribution, offers a realistic view on the subject of cloud computing and puts a list of useful and timely reflections and recommendations within reach of those who are effectively interested in them, by proper will or due to duties.
\end{abstract}

Keywords: Information technology, Cloud computing, Risk management, Delphi method. 



\section{SUMÁRIO}

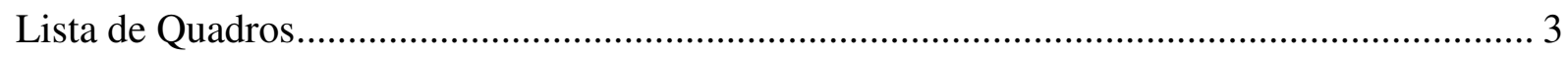

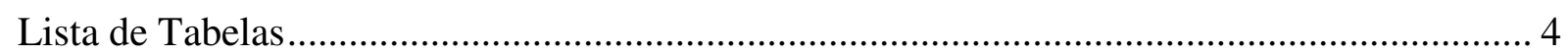

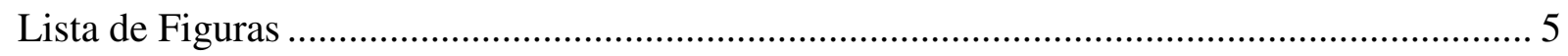

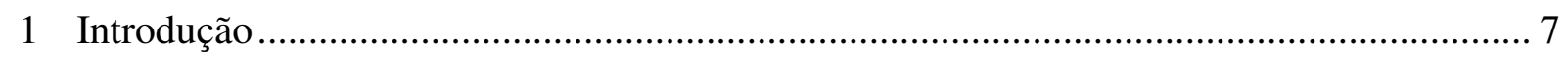

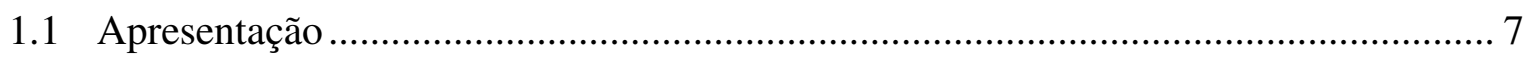

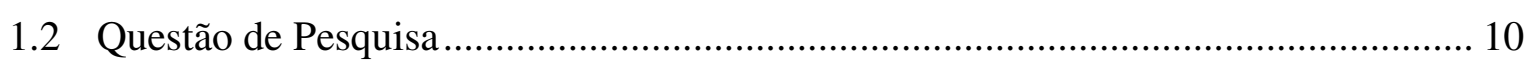

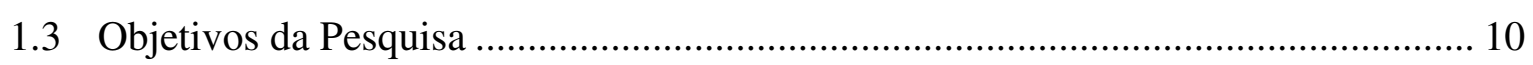

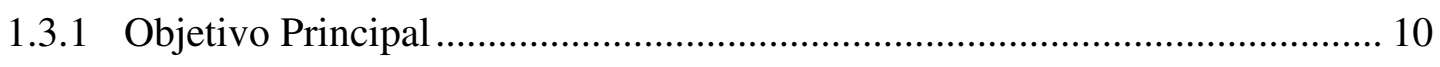

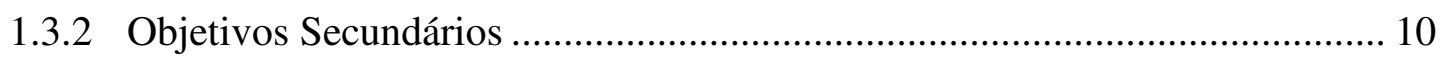

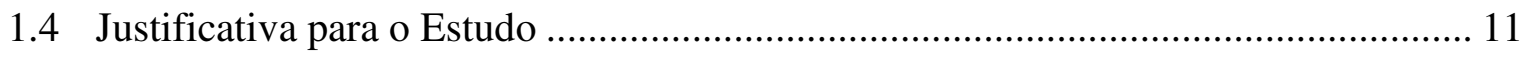

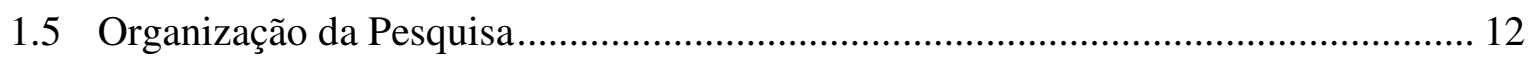

2 Revisão da Literatura e Considerações........................................................................ 13

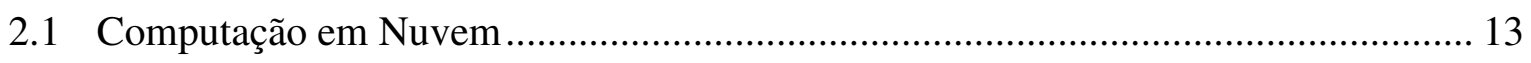

2.1.1 Histórico e Definições para Computação em Nuvem..................................... 13

2.1.2 Semelhanças nas Definições para Computação em Nuvem ........................... 16

2.1.3 Modelos de Referência para Computação em Nuvem.................................... 17

2.1.4 Semelhanças, Divergências, Pontos Fortes e Deficiências dos Modelos de Referência para Computação em Nuvem .................................................. 20

2.1.5 Benefícios Potenciais Associados à Computação em Nuvem ....................... 21

2.1.6 Barreiras Potenciais Inibidoras da Adoção da Computação em Nuvem ........ 25

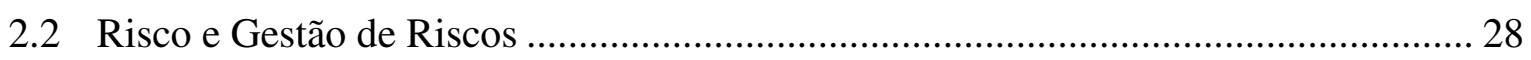

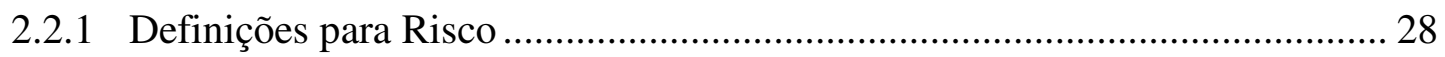

2.2.2 Definições e Roteiros para Gestão de Riscos ................................................. 30

2.2.3 Riscos Inerentes à TI e Gestão de Riscos em TI ........................................... 35

2.2.4 Riscos Inerentes à Computação em Nuvem ................................................. 40

2.2.5 Considerações Sobre a Questão do Risco na Computação em Nuvem .......... 46

2.2.6 Gestão de Riscos na Computação em Nuvem ............................................... 47

2.2.7 Considerações Sobre as Proposições Relativas à Segurança e à Gestão de Riscos na Computação em Nuvem ........................................................... 51

3 Método de Pesquisa ........................................................................................................... 53

3.1 O Método Delphi: Definição e Histórico .................................................................... 53

3.2 Modalidades e Sistemáticas de Aplicação do Método Delphi .................................... 55

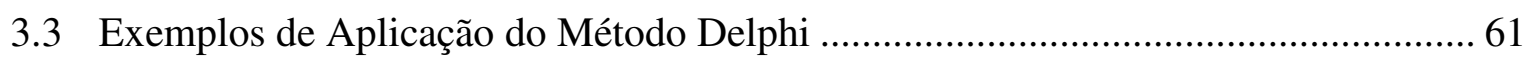

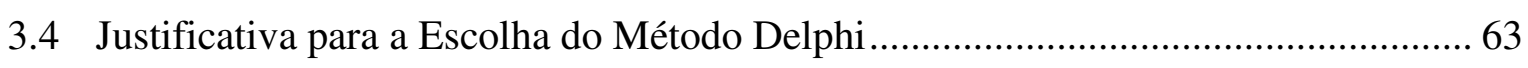

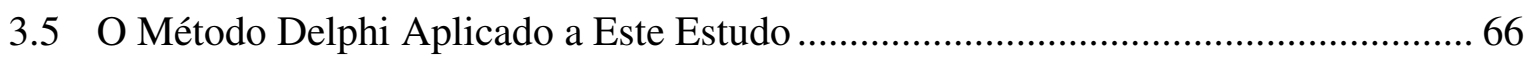

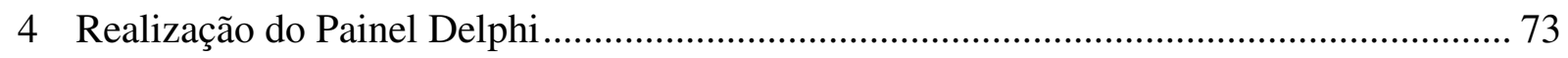

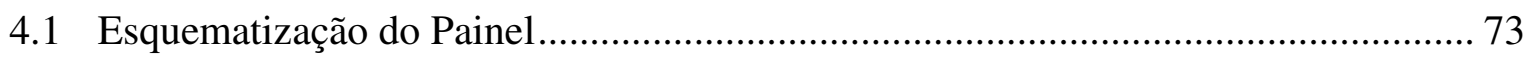




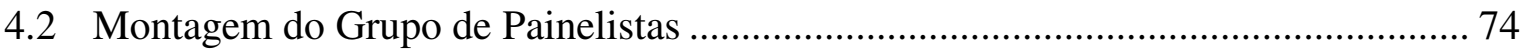

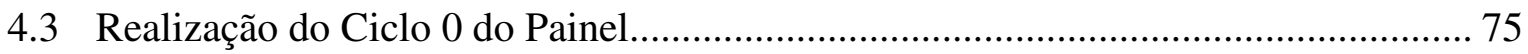

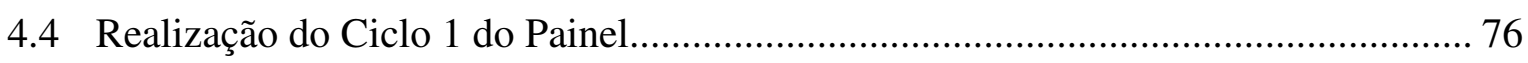

4.5 Realização do Ciclo 2 do Painel........................................................................... 78

4.5.1 Preparo da Questão Relativa às Barreiras .................................................... 78

4.5.2 Preparo da Questão Relativa aos Benefícios ............................................... 79

4.5.3 Respostas Relativas às Barreiras e Benefícios.............................................. 79

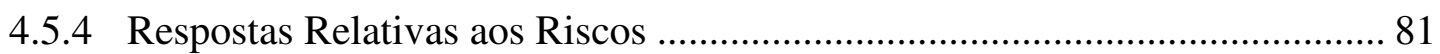

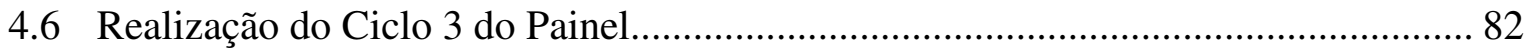

4.6.1 Preparo da Questão Relativa aos Riscos ..................................................... 83

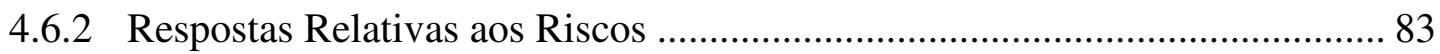

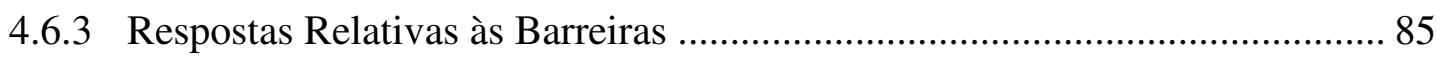

4.6.4 Respostas Relativas aos Benefícios .......................................................... 87

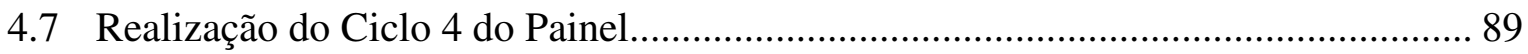

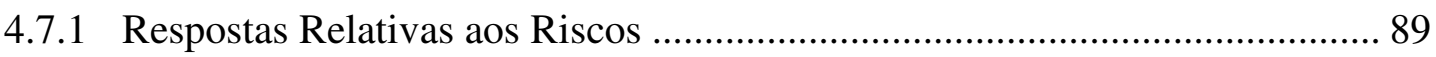

4.7.2 Respostas Relativas às Barreiras ................................................................. 91

4.7.3 Respostas Relativas aos Benefícios …….................................................... 93

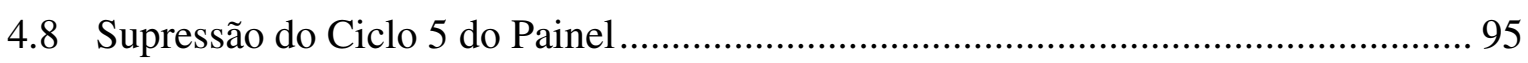

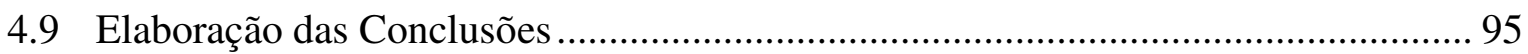

5 Recomendações para o Tratamento dos Riscos Inerentes à Computação em Nuvem ....... 97

5.1 Riscos Inerentes à Computação em Nuvem........................................................... 97

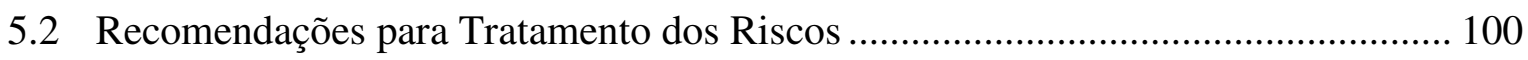

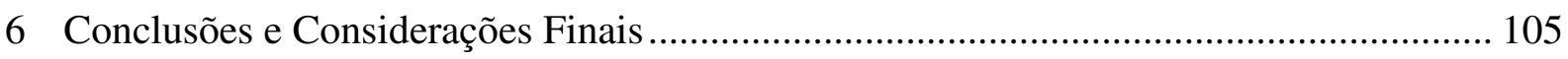

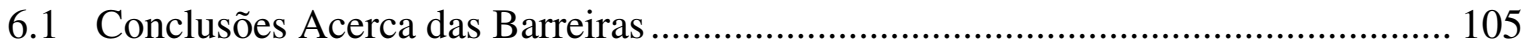

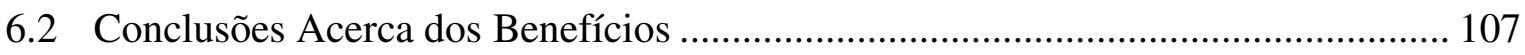

6.3 Conclusões Acerca dos Riscos e seu Tratamento .................................................... 109

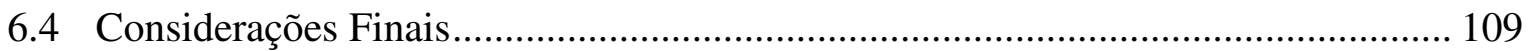

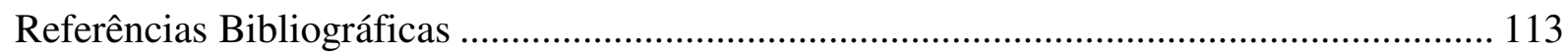

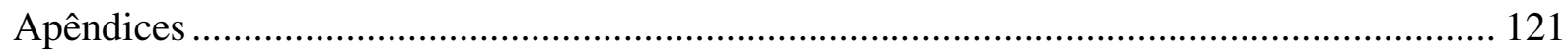




\section{LISTA DE QUADROS}

Quadro 1 - Definições para "Computação em Nuvem" ........................................................... 14

Quadro 2 - Definições de Acadêmicos para "Computação em Nuvem" ................................. 14

Quadro 3 - Modelo de Referência do NIST para Computação em Nuvem............................. 17

Quadro 4 - Benefícios Potenciais Associados à Computação em Nuvem .............................. 24

Quadro 5 - Barreiras Potenciais Inibidoras da Adoção da Computação em Nuvem............... 27

Quadro 6 - Graus de Qualificação das Disciplinas Focais de Gestão dos Riscos da TI.......... 38

Quadro 7 - Riscos de Origem Técnica Presentes na Computação em Nuvem........................ 45

Quadro 8 - Consolidação dos Riscos Inerentes à Computação em Nuvem.............................. 46

Quadro 9 - Princípios Práticos para Aplicação do Método Delphi ......................................... 60

Quadro 10 - Comparação Entre Sistemáticas de Aplicação do Método Delphi...................... 67

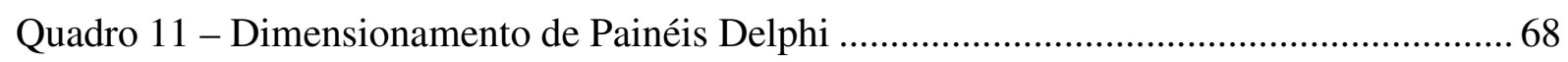

Quadro 12 - Barreiras Potenciais à Adoção da Computação em Nuvem Não Privada

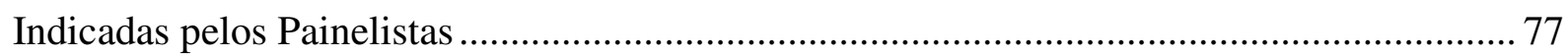

Quadro 13 - Benefícios Potenciais Decorrentes da Adoção da Computação em Nuvem Não

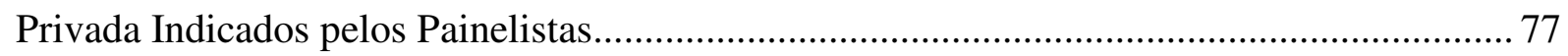

Quadro 14 - Riscos Potenciais Decorrentes da Adoção da Computação em Nuvem Não

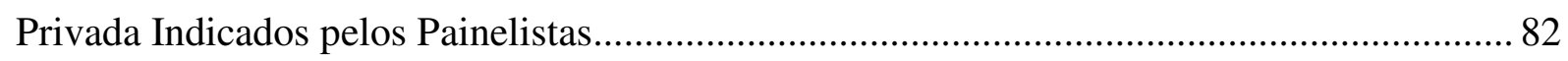

Quadro 15 - Ranking de Riscos Potenciais Inerentes à Computação em Nuvem Não Privada

Quadro 16 - Ranking de Barreiras Potenciais à Adoção da Computação em Nuvem Não

Privada.

Quadro 17 - Ranking de Benefícios Potenciais Decorrentes da Adoção da Computação em

Nuvem Não Privada 


\section{LISTA DE TABELAS}

Tabela 1 - Barreiras Mais Relevantes (Opinião dos Painelistas)............................................ 80

Tabela 2 - Benefícios Mais Relevantes (Opinião dos Painelistas) ......................................... 81

Tabela 3 - Riscos Mais Relevantes (Opinião dos Painelistas)................................................ 84

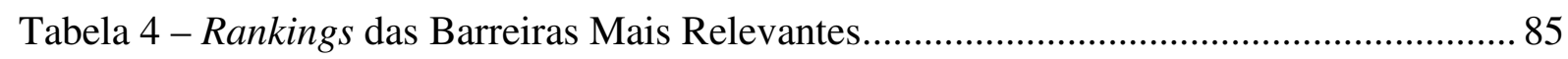

Tabela 5 - Rankings das Barreiras Mais Relevantes (Acadêmicos) ……............................... 86

Tabela 6 - Rankings das Barreiras Mais Relevantes (Profissionais de TI).............................. 86

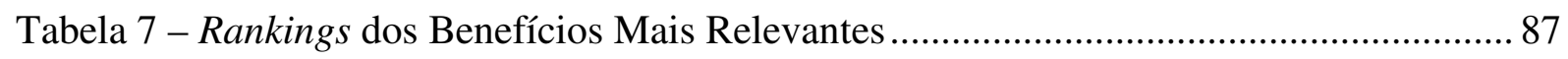

Tabela 8 - Rankings dos Benefícios Mais Relevantes (Acadêmicos) ...................................... 88

Tabela 9 - Rankings dos Benefícios Mais Relevantes (Profissionais de TI) ........................... 88

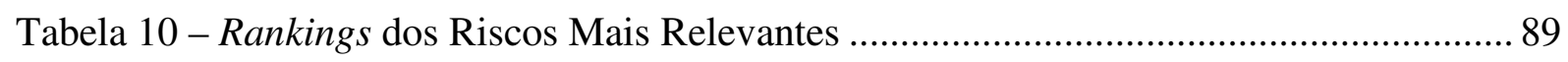

Tabela 11 - Rankings dos Riscos Mais Relevantes (Acadêmicos) .......................................... 90

Tabela 12 - Rankings dos Riscos Mais Relevantes (Profissionais de TI) .............................. 90

Tabela 13 - Rankings das Barreiras Mais Relevantes (Após Revisão).................................... 91

Tabela 14 - Rankings das Barreiras Mais Relevantes (Acadêmicos Após Revisão)................ 92

Tabela 15 - Rankings das Barreiras Mais Relevantes (Profissionais de TI Após Revisão) .... 92

Tabela 16 - Rankings dos Benefícios Mais Relevantes (Após Revisão) ................................. 93

Tabela 17 - Rankings dos Benefícios Mais Relevantes (Acadêmicos Após Revisão) ............. 94

Tabela 18 - Rankings dos Benefícios Mais Relevantes (Profissionais de TI Após Revisão).. 94 


\section{LISTA DE FIGURAS}

Figura 1 - Estágios da Terceirização de Serviços de TI ........................................................ 8

Figura 2 - Estimativa de Gastos com Computação em Nuvem ............................................... 9

Figura 3 - Representação Gráfica do Modelo do NIST para Computação em Nuvem ........... 19

Figura 4 - Ofertas de Serviços em Nuvens vs. Tecnologias de Acesso................................... 19

Figura 5 - Representação Gráfica do Cubo da Nuvem .......................................................... 20

Figura 6 - Diagrama Explicativo das Situações de Segurança e Perigo .................................. 28

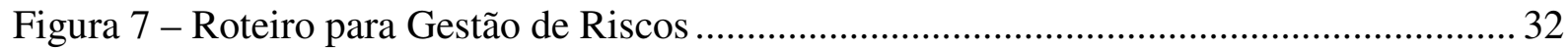

Figura 8 - Modelo Ampliado para Gestão de Riscos................................................................. 32

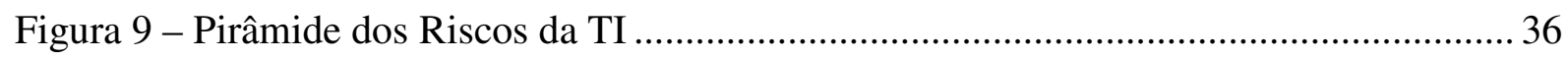

Figura 10 - Etapas da Governança dos Riscos da TI .......................................................... 37

Figura 11 - Processo de Gestão dos Riscos da TI................................................................. 39

Figura 12 - Sistemática para Aplicação do Método Delphi em 3 Ciclos .................................58

Figura 13 - Sistemática para Escolha de Especialistas para um Painel Delphi ....................... 60

Figura 14 - Ciclos de Aplicação do Método Delphi Neste Estudo........................................... 73

Figura 15 - Etapas Destacadas da Gestão dos Riscos da TI ................................................. 100 


\section{INTRODUÇÃO}

\section{$1.1 \quad$ Apresentação}

Na busca por serviços de Tecnologia da Informação, TI, com melhores relações benefício/ custo, as instituições e organizações de negócios têm optado por mesclar serviços de provimento próprio com os adquiridos de terceiros. Neste último decênio, cresceram e se diversificaram de modo significativo tanto a procura quanto a oferta de serviços de TI por parte, respectivamente, de clientes em potencial e provedores dos mais diversos tipos.

De uma oferta, no passado, centrada em recursos de infra-estrutura e na cessão de direitos de uso de aplicativos, o leque se abriu para serviços da mais diversa natureza. Esta evolução e diversificação acabaram por propiciar o surgimento de serviços contratáveis sob demanda e com a característica de permitir aos tomadores optar por adquirir pacotes que englobam tanto recursos de software quanto de hardware e de comunicação de dados, pacotes estes secundados por compromissos de atendimento dentro de padrões de nível de serviço. Nesta formatação, torna-se indiferente aos tomadores dos serviços o local onde fisicamente o processamento ocorre ou mesmo onde os dados são armazenados, importando a disponibilização dos resultados acordados, com o nível de atendimento pactuado.

A computação está se tornando uma utilidade e, uma vez mais, as regras econômicas que determinam o modo de trabalhar e viver das pessoas estão sendo reescritas, à semelhança do que ocorreu no passado, por exemplo, com a eletricidade e a telefonia. Data centers operados isoladamente por empresas estão sendo substituídos por serviços providos num ambiente comum, a Internet, por instalações centralizadas de processamento de dados. Face às vantagens econômicas do modelo de utilidades, as instituições e organizações estão repensando o modo pelo qual se dispõem a comprar e usar a TI - ao invés de destinar volumes expressivos de recursos de caixa para adquirir computadores e programas, elas estão considerando conectar-se a este novo ambiente. Trata-se de uma mudança tão significativa que promete não apenas impactar a função de TI das instituições e organizações, mas também surpreender a indústria da computação como um todo (CARR, 2008). 
Esta nova forma de prestação de serviços de TI foi rotulada "computação em nuvem", expressão traduzida da original em inglês "cloud computing". O instituto de pesquisas Forrester Research, por exemplo, elaborou um modelo que busca explicitar os diferentes estágios da terceirização de serviços de TI, com base na tecnologia aplicada e no modo de oferecimento desses serviços. Neste modelo, reproduzido na Figura 1, a computação em nuvem é referenciada como a modalidade mais evoluída de terceirização de serviços de TI (STATEN et al., 2008).

Figura 1 - Estágios da Terceirização de Serviços de TI

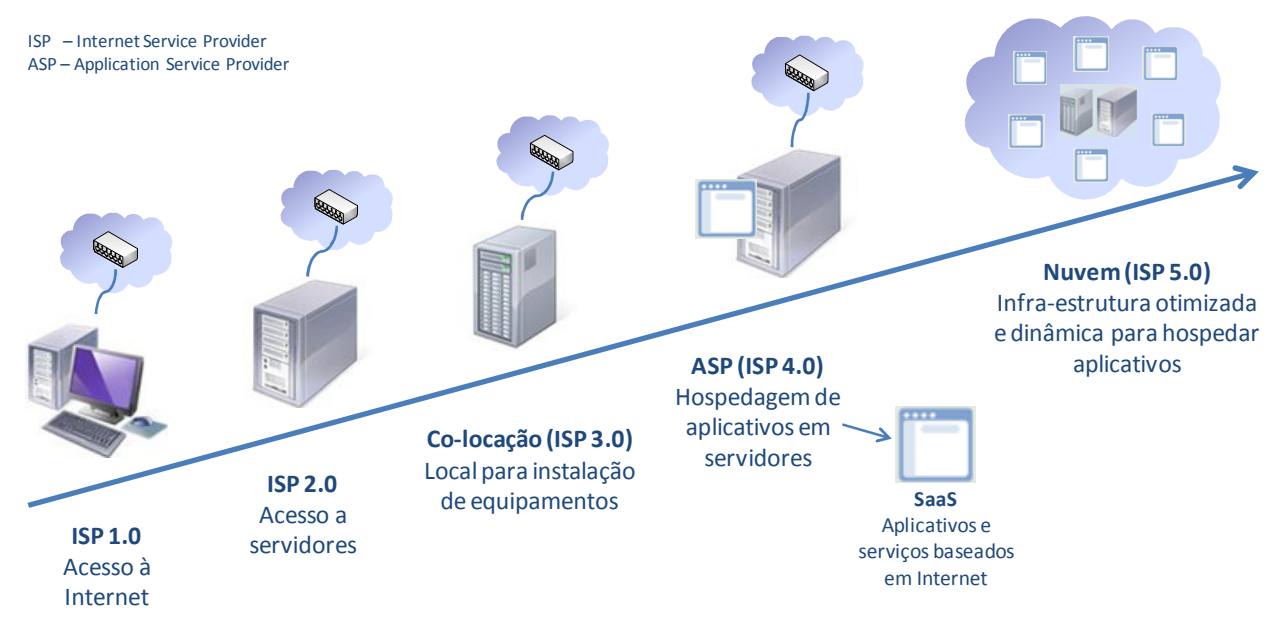

FONTE: Adaptado de STATEN et al.; 2008; p. 7.

Apesar de se constituir numa modalidade relativamente nova de terceirização de serviços de TI, a computação em nuvem já conta com um leque bastante razoável de ofertas e provedores. A OpenCrowd (2010), prestadora de serviços de TI, relaciona 18 distintos tipos de serviços oferecidos por meio de nuvens, por cerca de duas centenas de provedores. A International Data Corporation, IDC (2010), especializada em estudos na área de TI, projeta um aumento significativo no volume de negócios de computação em nuvem até 2014 (alguns números desta pesquisa estão apresentados na Figura 2).

Entretanto, apesar dos aspectos positivos e dos benefícios potenciais que a cercam, a computação em nuvem, como toda novidade, está sujeita a imperfeições e anormalidades, mais ainda por se tratar de algo intangível, como é o caso dos serviços. Nesse contexto, é natural, e até esperado, que os tomadores destes serviços enfrentem barreiras e fiquem expostos a um nível de risco nem sempre visível, às vezes excessivo e de difícil mensuração. 
Figura 2 - Estimativa de Gastos com Computação em Nuvem
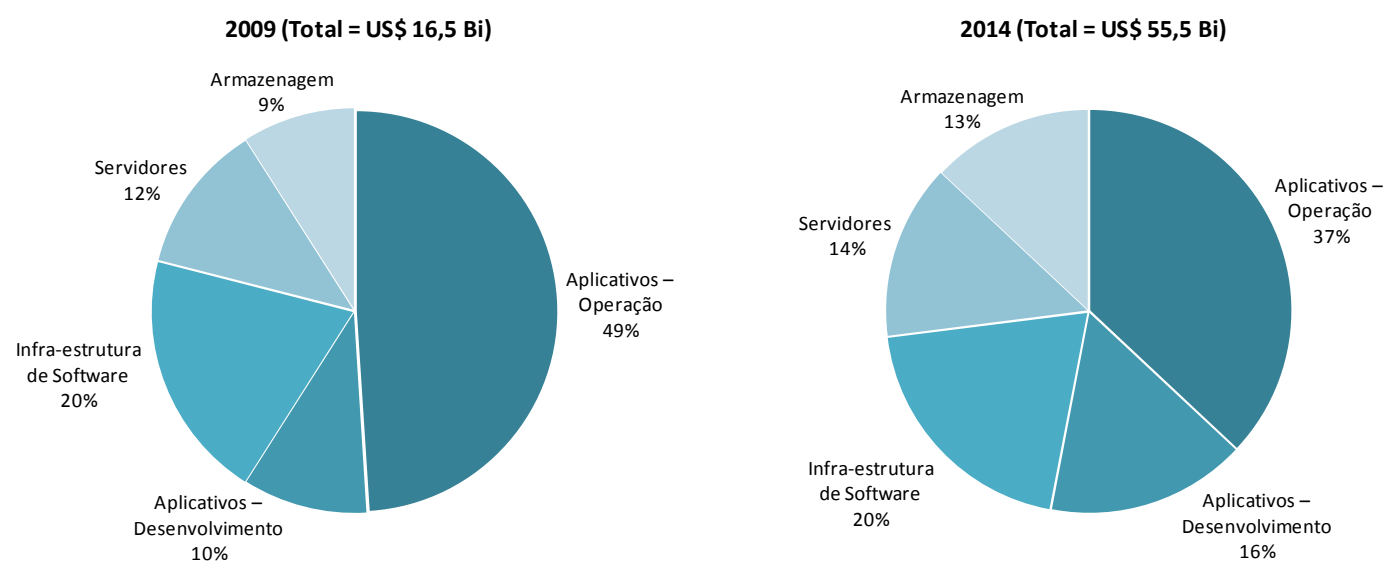

FONTE: Adaptado de IDC; 2010.

Vêm sendo notados esforços por parte da comunidade de fornecedores, no sentido de tornar menos impactantes as barreiras e de tratar de forma mais estruturada os riscos inerentes a este novo tipo de oferta. Do mesmo modo, os tomadores de serviços também vêm se organizando, com vistas a superar as barreiras e a exigir padrões mínimos aceitáveis de risco e segurança a serem implementados nas ofertas, para poder, como contrapartida, usufruir dos benefícios potenciais da computação em nuvem.

Dada esta realidade, aparentava ser de muita valia (e, de fato, tornou-se o fator motivador deste estudo) uma análise mais detalhada de todos esses esforços, focada particularmente nos consumidores desta modalidade de serviços, de modo a:

- Identificar e apresentar, de uma maneira ordenada, as propostas até então colocadas para o tratamento das questões das barreiras e dos riscos inerentes à computação em nuvem;

- Explicitar as semelhanças e divergências verificadas nas distintas proposições identificadas, bem como seus pontos fortes e deficiências;

- Explorar e verificar a pertinência e adequação das recomendações constantes das proposições identificadas;

- Propor um elenco de recomendações endereçadas ao tratamento dos riscos em ambientes de computação em nuvem. 


\subsection{Questão de Pesquisa}

Dado o contexto acima apresentado, a questão de pesquisa considerada neste estudo foi: "Como reconhecer e lidar com os riscos inerentes à adoção da computação em nuvem, sob a ótica dos consumidores desta modalidade de serviços?"

Para responder a esta questão, foram explorados em detalhe os conceitos de computação em nuvem, de risco e de gestão de riscos e entendeu-se como adoção o ato voluntário de adquirir um determinado serviço ou conjunto de serviços agregados. No âmbito das instituições e organizações de negócio, a adoção, via de regra, é amparada por um processo formal de aquisição, por conta do qual são feitas chamadas de fornecedores, cotações de preços, formalização de contratos e outros processos correlatos.

\subsection{Objetivos da Pesquisa}

\subsubsection{Objetivo Principal}

O objetivo principal desta pesquisa pode ser enunciado como "fazer recomendações com vistas a auxiliar consumidores de serviços de computação em nuvem a tratar a questão dos riscos, ou seja, identificá-los, compreendê-los e preparar-se para gerenciá-los, de modo tal a poder, nesses ambientes, contratar serviços com grau aceitável de risco".

\subsubsection{Objetivos Secundários}

Complementando o objetivo principal acima explicitado, fixaram-se os seguintes objetivos secundários para a pesquisa:

- Identificar os benefícios potenciais citados em estudos acadêmicos como passíveis de ser obtidos, pelos consumidores de serviços, com a adoção da computação em nuvem;

- Identificar e apresentar, de maneira ordenada, as propostas oriundas do meio acadêmico para o tratamento, por parte dos consumidores de serviços, das questões das barreiras e dos riscos inerentes à computação em nuvem;

- Explicitar semelhanças, divergências, pontos fortes e deficiências das distintas propostas identificadas, relativamente a barreiras e benefícios; 
- Explorar e verificar a pertinência e adequação dos benefícios apontados e das recomendações relativas a barreiras e riscos constantes das propostas identificadas.

\subsection{Justificativa para o Estudo}

Um estudo da natureza deste aqui proposto justifica-se, no momento presente, sob dois distintos enfoques: o acadêmico e o profissional.

No que diz respeito ao mundo acadêmico, este trabalho vem preencher uma lacuna, dado que não nos foi possível encontrar, na pesquisa bibliográfica realizada, nenhum outro esforço assemelhado, seja no meio acadêmico brasileiro seja no internacional. A pesquisa bibliográfica, empregando os argumentos "cloud computing" e "computação em nuvem", abrangeu consultas às bases ProQuest, Scielo e EnANPAD e buscas no Google (www.google.com). Os trabalhos e pesquisas identificados e analisados, ainda que bem estruturados e consubstanciados, representam visões particulares e isoladas sobre os temas aqui tratados, sem focar, entretanto, a comparação ou a convergência de visões.

Em decorrência, entendemos que este trabalho pode oferecer uma contribuição efetiva ao tratamento das questões dos benefícios, barreiras e riscos que envolvem as ofertas de serviços em ambientes de computação em nuvem. Senão por outro motivo, este trabalho, no mínimo, tem o mérito de produzir e disponibilizar um material relativo ao tema, útil a pesquisadores e acadêmicos.

Por outro lado, sob o ponto de vista do ambiente profissional, há também não apenas uma lacuna, mas toda uma diversidade de agentes, enfoques, terminologias e proposições referentes aos temas objeto desta pesquisa, diversidade esta que já está a requerer, se não uma padronização, ao menos uma unificação, que possa proporcionar aos tomadores de serviços avaliarem de maneira mais homogênea as ofertas que lhes são apresentadas. 


\subsection{Organização da Pesquisa}

Tendo em vista o tema central e a questão de pesquisa definidos e ainda os objetivos estabelecidos, o seguinte roteiro de trabalho foi projetado para a pesquisa e cumprido:

- Fase 1 - Revisão da literatura e considerações:

- Contemplou uma ampla revisão da literatura referente ao tema central da pesquisa, a computação em nuvem, e a elaboração de considerações sobre os tópicos explorados barreiras, benefícios e riscos.

- Fase 2 - Escolha e estruturação do método de pesquisa:

- Compreendeu uma segunda rodada de revisão da literatura, desta feita focando o método Delphi, adotado como instrumento metodológico principal do estudo;

- Adicionalmente, englobou a definição da sistemática de aplicação do método Delphi a este estudo em particular.

- Fase 3 - Realização do painel Delphi:

- Objetivou a estruturação e realização propriamente ditas do painel e contemplou ainda a análise dos resultados obtidos em cada ciclo.

- Fase 4 - Proposição de recomendações para o tratamento dos riscos:

- Abrangeu a análise dos resultados obtidos no painel, relativamente aos riscos inerentes à computação em nuvem e culminou com a definição das recomendações visando atender ao objetivo principal estabelecido para a pesquisa.

- Fase 5 - Conclusões e considerações finais:

- Compreendeu a elaboração das conclusões e considerações finais, à luz dos resultados obtidos durante os trabalhos.

A documentação produzida ao longo de cada uma das fases deste roteiro compõe os distintos capítulos nos quais esta monografia está subdividida a partir deste ponto. 


\section{REVISÃO DA LITERATURA E CONSIDERAÇÕES}

Neste capítulo são abordados, de início, os conceitos de computação em nuvem, risco, segurança e gestão de riscos, temas em torno dos quais está estruturado este estudo. Para cada um dos temas, são apresentadas as principais definições extraídas das referências bibliográficas pesquisadas. Especificamente para a computação em nuvem, são ainda destacados os benefícios que sua utilização pode propiciar aos consumidores e as barreiras que podem inibir sua adoção e descritos os principais modelos de referência desenvolvidos até o momento. Relativamente ao risco, são explorados, em adição, alguns modelos de gestão de riscos e, em particular, os riscos inerentes à TI e à computação em nuvem.

Complementando o capítulo, são feitas considerações relativas às definições, conceitos e modelos descritos, enfatizando semelhanças, divergências, pontos fortes e deficiências e destacando as definições e modelos mais representativos.

\subsection{Computação em Nuvem}

\subsubsection{Histórico e Definições para Computação em Nuvem}

Aymerich et al. (2008) afirmam que a expressão "computação em nuvem" foi empregada pela primeira vez em 2006 pelo Chief Executive Officer, CEO, do Google, Eric Schmidt, para referenciar a computação empregando os recursos da Internet. De fato, a literatura, tanto acadêmica quanto não-acadêmica, não registra o emprego desta expressão antes de 2006. Portanto, tenha sido ou não Schmidt o responsável por cunhar a expressão, a realidade é que ela parece mesmo não ter sido referenciada em período anterior.

De todo modo, desde o seu surgimento, diversos autores, organizações e instituições têm procurado definir a expressão "computação em nuvem". Smith (2009) oferece um resumo de definições propostas por organizações e instituições de renome, definições estas que estão reproduzidas no Quadro 1. 
Quadro 1 - Definições para "Computação em Nuvem"

\begin{tabular}{ll}
\hline Organização & Definição \\
\hline \hline Gartner Group & $\begin{array}{l}\text { "Estilo de computação no qual recursos de TI, massivamente escaláveis, são } \\
\text { disponibilizadas sob a forma de serviços, por meio da Internet, para múltiplos } \\
\text { consumidores externos." }\end{array}$ \\
\hline $\begin{array}{l}\text { Forrester } \\
\text { Research }\end{array}$ & "Um conjunto de infra-estruturas gerenciadas, abstratas e altamente escaláveis, capazes \\
\hline The 451 Group & "TI oferecida como serviço, disponibilizada por meio de recursos independentes de \\
& localização física." \\
\hline Wikipedia & "Um estilo de computação no qual recursos dinamicamente escaláveis e, em geral, \\
& virtualizados são providos como serviços por meio da Internet." \\
\hline $\begin{array}{l}\text { International } \\
\text { Business }\end{array}$ & $\begin{array}{l}\text { "Plataforma que dinamicamente provê, configura, re-configura e libera servidores de } \\
\text { Machines, IBM }\end{array}$ \\
\hline nos quais hospeda aplicações e serviços para serem utilizados via Internet."
\end{tabular}

FONTE: Adaptado de SMITH; 2009; p. 66.

Por outro lado, recorrendo ao mundo acadêmico, não são muito distintas das acima as definições propostas em ensaios e pesquisas que abordam este tema. O Quadro 2 congrega algumas definições deste tipo.

Quadro 2 - Definições de Acadêmicos para "Computação em Nuvem"

\begin{tabular}{ll}
\hline Ano Autor & Definição \\
\hline \hline 2007 Weiss & "O conceito de nuvem lida com muitas tecnologias e arquiteturas já existentes. A \\
& centralização de recursos de computação não é uma novidade, mas um retorno às \\
& raízes, assim como não são novidades a computação utilitária, a computação \\
& distribuída e o software como serviço. Mas a nuvem inova, ao integrar todos \\
& esses modelos de computação. E esta integração requer a mudança do centro de \\
& poder, dos processadores para a rede - dentro da nuvem, os processadores \\
& tornam-se commodities e é a rede que mantém uma nuvem una e conecta nuvens \\
& umas às outras, bem como o céu ao chão."
\end{tabular}

2009 Armbrust et al. "Computação em nuvem refere-se tanto às aplicações disponibilizadas via Internet sob a forma de serviços quanto aos equipamentos e sistemas oferecidos pelos data centers que os provêem; os serviços desta natureza têm sido já há algum tempo denominados SaaS (da sigla em inglês para a expressão "software as a service") e esta é uma denominação que continuaremos a utilizar; já os equipamentos e o software constituem o que denominaremos nuvem."

2009 Bandyopadhyay "É um modelo de serviço em TI no qual os serviços de computação (tanto de et al. hardware quanto de software) são entregues sob demanda a consumidores conectados a uma rede, sob a forma de auto-serviço, independentemente de equipamentos e localização. Os recursos requeridos para prover os serviços com níveis de qualidade adequados são compartilhados, dinamicamente escaláveis, rapidamente disponibilizados, virtuais e liberados com uma interação mínima com o provedor. Os consumidores pagam pelo uso dos serviços, sem terem que 
Quadro 2 - Definições de Acadêmicos para "Computação em Nuvem" (cont.)

\begin{tabular}{|c|c|c|}
\hline Ano & Autor & Definição \\
\hline 2009 & $\begin{array}{l}\text { Bandyopadhyay } \\
\text { et al. (cont.) }\end{array}$ & $\begin{array}{l}\text { incorrer em investimentos iniciais de porte, e os serviços em nuvem empregam } \\
\text { sistemas de medição que dividem os recursos computacionais em blocos } \\
\text { apropriados para a cobrança." }\end{array}$ \\
\hline 2009 & Buyya et al. & $\begin{array}{l}\text { "Uma nuvem é um tipo de sistema paralelo e distribuído, composto por um } \\
\text { conjunto de computadores interconectados e virtualizados, que são } \\
\text { dinamicamente disponibilizados como sendo um ou mais recursos unificados de } \\
\text { computação, baseados em acordos de nível de serviço estabelecidos por meio de } \\
\text { negociação entre o provedor e os consumidores." }\end{array}$ \\
\hline 2009 & Gatewood & $\begin{array}{l}\text { "Em geral, nuvens são grandes conjuntos de recursos virtuais de fácil acesso e } \\
\text { utilização (por exemplo, equipamentos, plataformas de desenvolvimento e/ou } \\
\text { serviços); estes recursos podem ser facilmente configurados para satisfazer } \\
\text { distintas demandas, possibilitando ao provedor ajustá-los para prover utilização } \\
\text { otimizada." }\end{array}$ \\
\hline 2009 & Grossman & $\begin{array}{l}\text { "Nuvens, ou clusters de computadores distribuídos, provêem recursos e serviços } \\
\text { sob demanda em uma rede, usualmente a Internet, com a escalabilidade e } \\
\text { confiabilidade de um data center." }\end{array}$ \\
\hline 2009 & Kim & $\begin{array}{l}\text { "Talvez a definição mais simples para computação em nuvem seja a capacidade } \\
\text { para acessar, via Internet, arquivos, dados, programas e serviços de terceiros, } \\
\text { que estão hospedados em um provedor externo e pagar apenas pelos recursos e } \\
\text { serviços utilizados." }\end{array}$ \\
\hline 2009 & Qian et al. & $\begin{array}{l}\text { "Computação em nuvem é um tipo de técnica computacional na qual serviços de } \\
\text { TI são providos por unidades dotadas de recursos massivos de baixo custo, } \\
\text { conectadas por redes de protocolo Internet." }\end{array}$ \\
\hline 2009 & Smith & $\begin{array}{l}\text { "Em essência, computação em nuvem é uma forma de alugar computadores, } \\
\text { espaço para armazenagem e capacidade de rede, em uma base de preços } \\
\text { horários, de alguma empresa que já dispõe desses recursos em seu próprio data } \\
\text { center e pode disponibilizá-los via Internet." }\end{array}$ \\
\hline 2009 & Veras & $\begin{array}{l}\text { "Na verdade, o conceito de computação em nuvem vem se aprimorando ao } \\
\text { longo do tempo, mas essencialmente trata de uma mesma ideia básica: processar } \\
\text { as aplicações e armazenar dados fora do ambiente corporativo." }\end{array}$ \\
\hline
\end{tabular}

Em adição às definições apresentadas nos Quadros 1 e 2, é adequado mencionar a definição proposta pelo National Institute of Standards and Technology, NIST, entidade federal nãoregulatória vinculada ao Departamento de Comércio do Governo dos Estados Unidos e responsável por promover a inovação e a competitividade industriais em âmbito nacional naquele país. Para o NIST (2009, p. 1):

"Computação em nuvem é um modelo que viabiliza o acesso oportuno e sob demanda a um pacote compartilhável de recursos computacionais configuráveis (por exemplo, redes, servidores, áreas para armazenagem, aplicativos e serviços) que podem ser rapidamente provisionados e liberados com um esforço mínimo de gestão ou de interação com o provedor dos serviços." ${ }^{1}$

\footnotetext{
1 "Cloud computing is a model for enabling convenient, on-demand network access to a shared pool of configurable computing resources (e.g., networks, servers, storage, applications, and services) that can be rapidly provisioned and released with minimal management effort or service provider interaction."
} 
Vale destacar ainda duas outras definições, pela aderência que apresentam para com relação à do NIST. A primeira delas é a da Cloud Security Alliance, CSA (2009), que abriu mão da sua definição original para adotar na íntegra a do NIST. A outra é a da F5 Networks (2009), prestadora de serviços de TI, que oferece uma definição derivada de um conjunto de outras obtidas da literatura (entre as quais a do NIST se faz presente com destaque) e fruto de um focus group realizado com profissionais de TI e com provedores de serviços em nuvem; a definição obtida, que, como se pode verificar, reproduz a do NIST na sua última parte, é:

"Computação em nuvem é um estilo de computação no qual recursos dinamicamente escaláveis e geralmente virtualizados são disponibilizados sob a forma de serviços. Os consumidores não necessitam possuir conhecimento, nem serem especialistas, nem tampouco exercer controle sobre a infra-estrutura tecnológica na nuvem. Além disso, a computação em nuvem emprega um modelo que viabiliza o acesso oportuno e sob demanda a um pacote compartilhável de recursos computacionais configuráveis (por exemplo, redes, servidores, áreas para armazenagem, aplicativos e serviços) que podem ser rapidamente provisionados e liberados com um esforço mínimo de gestão ou de interação com o provedor dos serviços." 2

Bandyopadhyay et al. (2009) destacam que a computação em nuvem representa a convergência de duas das principais tendências: eficiência em TI e agilidade nos negócios. A capacidade dos computadores modernos possibilita seu uso de maneira mais eficiente, empregando recursos altamente escaláveis. Para introduzir agilidade nos negócios, a TI pode ser usada como um instrumento competitivo, viabilizando o desenvolvimento rápido de aplicações, o processamento em paralelo, o uso de ferramentas analíticas de alto desempenho e o emprego de aplicativos móveis interativos, que respondem em tempo real aos requisitos dos usuários.

\subsubsection{Semelhanças nas Definições para Computação em Nuvem}

Ao todo, no tópico acima foram destacadas 19 definições para computação em nuvem, número este que corresponde à soma das seis constantes do Quadro 1, com as dez do Quadro 2 e as três adicionais oferecidas, respectivamente, pelo NIST, pela CSA e pela F5 Networks.

\footnotetext{
2 "Cloud computing is a style of computing in which dynamically scalable and often virtualized resources are provided as a service. Users need not have knowledge of, expertise in, or control over the technology infrastructure in the 'cloud' that supports them. Furthermore, cloud computing employs a model for enabling available, convenient and on-demand network access to a shared pool of configurable computing resources (e.g., networks, servers, storage, applications, services) that can be rapidly provisioned and released with minimal management effort or service provider interaction."
} 
No geral, as definições focam a questão dos serviços em si, mais do que os aspectos técnicos que envolvem a infra-estrutura requerida para que as ofertas de serviços se materializem. Entre boa parte dessas definições, há pontos claros de convergência, em particular em torno das questões do compartilhamento de recursos externos, da escalabilidade, flexibilidade e custo sob demanda.

Pela maneira como foi elaborada, fruto de um focus group realizado com profissionais de TI e provedores de serviços de computação em nuvem, a definição oferecida pelo F5 Networks se apresenta como uma das mais completas, apesar de um tanto extensa.

Conforme já destacado, a definição do NIST assume um papel quase que de referência, dada a importância deste órgão no meio governamental norte-americano e também ao fato de ser constituída por norte-americanos ou radicados nos Estados Unidos boa parte dos autores e instituições que têm se ocupado do estudo da computação em nuvem.

\subsubsection{Modelos de Referência para Computação em Nuvem}

O NIST (op. cit.) propõe um modelo de referência para a computação em nuvem que considera a existência de três distintas dimensões: (a) características essenciais, (b) ofertas de serviços e (c) modelos de implementação. Resumidamente, em cada uma dessas dimensões pode-se destacar os aspectos que estão apresentados no Quadro 3.

Quadro 3 - Modelo de Referência do NIST para Computação em Nuvem

Dimensão/Item Descrição

Características Essenciais

Auto-serviço Os consumidores podem, unilateralmente, provisionar capacidade computacional, à sob demanda medida das necessidades e automaticamente, sem que seja requerida interação humana com os provedores dos serviços.

Acesso amplo Capacidades estão disponíveis na rede e são acessadas por meio de mecanismos à rede padronizados que possibilitam o uso via distintas plataformas de hardware.

Pool de Os recursos computacionais dos provedores são agrupados, de modo a servir a recursos múltiplos consumidores simultaneamente, com distintos recursos físicos e virtuais alocados e realocados dinamicamente de acordo com a demanda; há um certo grau de independência quanto à localização, fazendo com que os consumidores não decidam sobre os locais exatos a partir dos quais acessarão os recursos, mas possam especificar essa localização em alto nível (por exemplo, país, estado ou até mesmo data center). 
Quadro 3 - Modelo de Referência do NIST para Computação em Nuvem (cont.)

\begin{tabular}{ll}
\hline Dimensão/Item & Detalhe \\
\hline \hline Características Essenciais (cont.) & $\begin{array}{l}\text { As capacidades podem ser rápida e elasticamente provisionadas, em alguns casos até de } \\
\text { Rápida } \\
\text { elasticidade }\end{array}$ \\
$\begin{array}{l}\text { forma automática, permitindo aumentar e reduzir dinamicamente as quantidades } \\
\text { contratadas; para um consumidor, as capacidades disponíveis para provisionamento } \\
\text { apresentam-se como praticamente ilimitadas e podem ser compradas em qualquer } \\
\text { quantidade a qualquer momento. }\end{array}$ \\
$\begin{array}{l}\text { Serviços } \\
\text { mensuráveis }\end{array}$ & $\begin{array}{l}\text { meio de mecanismos inseridos em níveis apropriados a cada tipo de serviço; assim, o } \\
\text { uso dos recursos pode ser controlado e reportado com transparência. }\end{array}$ \\
\hline
\end{tabular}

$\underline{\text { Ofertas de Serviços }}$

Software como Os serviços disponibilizados são representados por aplicativos executados numa infraserviço (SaaS) estrutura em nuvem e acessados via um browser; os consumidores não gerenciam essa infra-estrutura, sejam redes, servidores, sistemas operacionais, áreas de armazenagem ou mesmo funcionalidades específicas dos aplicativos, exceto a definição de determinados parâmetros.

Plataforma Os serviços disponibilizados possibilitam executar aplicativos desenvolvidos pelos como serviço consumidores ou por estes adquiridos de terceiros, usando linguagens de programação (PaaS) e ferramentas suportadas pela nuvem; os consumidores não gerenciam essa infraestrutura, sejam redes, servidores, sistemas operacionais ou áreas de armazenagem, mas apenas controlam os aplicativos e podem configurar o ambiente.

Infra-estrutura Os serviços disponibilizados são o provisionamento e uso de recursos de infracomo serviço estrutura, como capacidade de processamento, áreas de armazenagem, redes e outros (IaaS) recursos computacionais básicos, de modo a possibilitar a execução de aplicativos e sistemas operacionais; os consumidores não gerenciam essa infra-estrutura, mas controlam os sistemas operacionais, áreas de armazenamento, aplicativos e, em alguns casos, podem até mesmo configurar componentes (por exemplo, firewalls).

\section{Modelos de Implementação}

Nuvem A infra-estrutura em nuvem é utilizada por uma única organização, pode ser gerida por Privada ela ou por terceiros e pode estar ou não instalada em local próprio dessa organização.

Nuvem A infra-estrutura em nuvem é compartilhada por várias organizações que compõem Comunitária uma comunidade específica, pode ser gerida por membros dessa comunidade ou por terceiros e pode estar ou não instalada em local próprio dessa comunidade.

Nuvem A infra-estrutura em nuvem é de propriedade de uma organização que se propõe a Pública comercializar os recursos e os disponibiliza aos consumidores em geral.

Nuvem A infra-estrutura em nuvem é uma combinação de dois ou dos três modelos acima, os Híbrida quais continuam a existir isoladamente, mas são integrados por meio de tecnologia proprietária ou aberta, que viabiliza a portabilidade de dados e aplicativos.

FONTE: Adaptado de NIST; 2009; p. 1-2.

A CSA (op. cit.) complementa o modelo de referência do NIST, oferecendo uma representação gráfica do mesmo (reproduzida na Figura 3) e, em adição, defende a inclusão de mais uma característica essencial no modelo, qual seja, a multi-tenancy, que ela considera indispensável para os aplicativos operados em nuvens. Multi-tenancy é a capacidade que os aplicativos modernos têm de, a partir de uma única instância em execução, processar independentemente dados de distintos usuários. 
Figura 3 - Representação Gráfica do Modelo do NIST para Computação em Nuvem

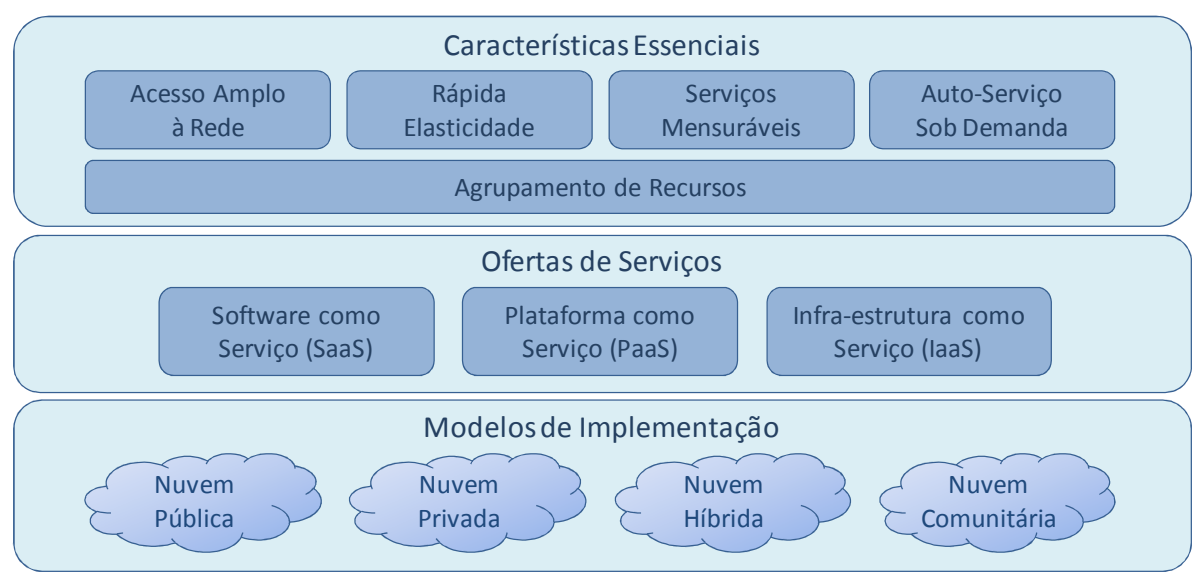

FONTE: Adaptado de CSA; 2009; p. 14.

Aymerich et al. (op. cit.), por seu turno, endossam as três dimensões propostas pelo NIST e consideram ainda a existência de um tipo adicional de oferta de serviços no modelo que propõem, tipo este que denominam "database as a service" e identificam pela sigla DaaS.

Já Jensen et al. (2009) utilizam a taxonomia da dimensão ofertas de serviços do NIST para propor uma arquitetura mais simplificada para a computação em nuvem, baseada naquela dimensão e na visão das tecnologias empregadas para viabilizar o acesso às ofertas, conforme mostra a Figura 4. As tecnologias de acesso consideradas neste caso compreendem os web browsers e os web services e sua interação com as ofertas se dá da seguinte forma:

- Web browsers suportam integralmente as ofertas de SaaS e uma parcela das de PaaS;

- Web services entram na composição das ofertas de IaaS e de parte das de PaaS.

Figura 4 - Ofertas de Serviços em Nuvens vs. Tecnologias de Acesso

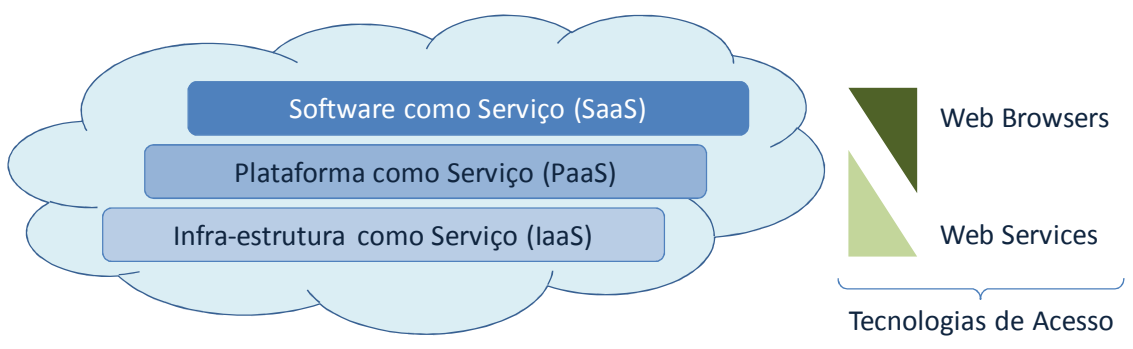

FONTE: Adaptado de JENSEN et al., 2009; p. 109. 
O Jericho Forum (2009), grupo de estudos vinculado a The Open Group, propõe um modelo estruturado a partir de quatro dimensões, ao qual denomina "cubo da nuvem" e que está graficamente apresentado na Figura 5; as dimensões consideradas dizem respeito a:

- Localização dos dados: interna ou externamente à organização à qual pertencem;

- Natureza dos recursos computacionais da nuvem: proprietários ou abertos;

- Arquitetura do ambiente: limitada a um perímetro ou ilimitada;

- Propriedade dos recursos alocados à nuvem: de terceiros ou da organização que se utiliza da nuvem.

Figura 5 - Representação Gráfica do Cubo da Nuvem

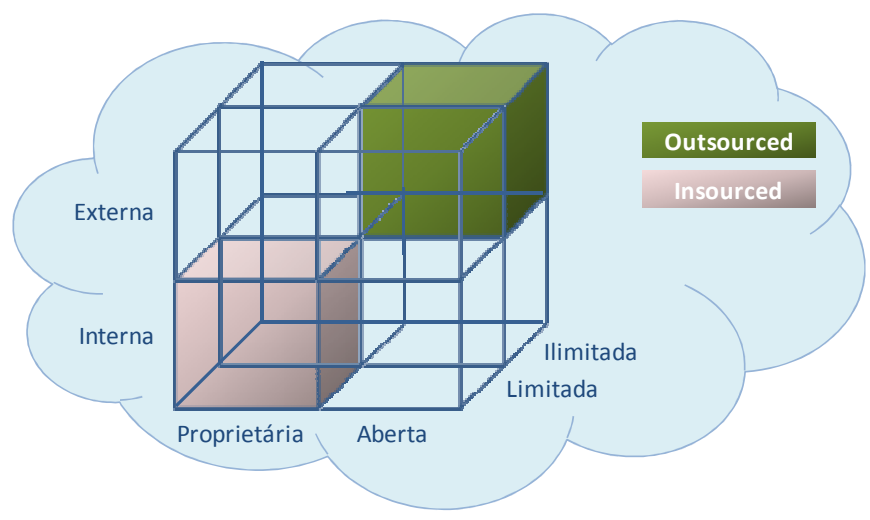

FONTE: Adaptado de JERICHO FORUM, 2009; p. 3.

\subsubsection{Semelhanças, Divergências, Pontos Fortes e Deficiências dos Modelos de Referência para Computação em Nuvem}

A revisão da literatura conduziu à identificação de diversos modelos de referência para computação em nuvem, dentre os quais cinco deles foram selecionados e estão apresentados no tópico acima.

O modelo proposto pelo NIST é, de longe, o mais referenciado na literatura, inclusive por alguns autores e entidades que não o declaram explicitamente, mas utilizam sua nomenclatura, em especial a que denomina as ofertas de serviços.

Dentre os demais modelos apresentados, os propostos pela CSA e por Aimerych et al. baseiam-se no do NIST, ao qual agregam extensões de pequena monta. O modelo de Jensen $e t$ 
al. abrange apenas uma das três dimensões introduzidas pelo NIST. O modelo do Jericho Forum, apesar de ser mais elaborado, é mais complexo e não acrescenta informações relevantes em grau proporcional ao aumento da complexidade.

\subsubsection{Benefícios Potenciais Associados à Computação em Nuvem}

Para Bandyopadhyay et al. (op. cit.), a computação em nuvem oferece um elenco significativo de benefícios-chave aos seus consumidores, a saber:

- Redução de custo:

- O custo de uso para as pequenas empresas é sensivelmente reduzido, habilitando-as a se beneficiar do uso de recursos computacionais antes apenas acessíveis a empresas de maior porte;

- Da mesma forma, pode-se deduzir que essa possibilidade de acesso se dá em nível de país, permitindo, dessa forma, a países em desenvolvimento queimar etapas no processo de informatização da sociedade.

- Redução de investimento inicial:

- O acesso a recursos computacionais se dá sem a necessidade de investimentos iniciais de monta, o que faz com que sua efetiva utilização se dê em um período de tempo menor;

- Como os gastos se dão sob a forma de custo operacional, ao invés de inversão em ativos, este fato também contribui para a diminuição dos valores a serem investidos antecipadamente;

- Em adição, na medida em que mais consumidores aderem aos serviços oferecidos por um determinado provedor, este tem condição de, face à economia de escala que pode obter, promover reduções de preço que venham a favorecer todo o seu elenco de consumidores.

- Redução de barreiras:

- A computação em nuvem tem potencial para reduzir as barreiras que a TI, em geral, impõe à inovação, o que é visivelmente demonstrado observando-se as inúmeras novas empresas que têm surgido, servindo-se de recursos computacionais em nuvem e que, em pouco tempo de atuação, são excepcionalmente bem sucedidas; nesta situação, podem ser citadas como exemplo YouTube, Facebook, TripIt e Mint. 
- Facilidade para escalar:

- A computação em nuvem torna fácil para as empresas escalar seus serviços de acordo com a demanda de seus clientes; uma vez que os recursos computacionais são manuseados via software, eles podem ser disponibilizados rapidamente à medida que novos equipamentos são adicionados à rede;

- Na realidade, o objetivo da computação em nuvem é possibilitar que os recursos sejam escalados dinamicamente, para mais ou para menos, por meio de software, dependendo da carga dos clientes, com a mínima interação possível com os provedores.

- Inovação:

- A computação em nuvem torna possíveis novas classes de aplicações e disponibiliza serviços não possíveis anteriormente.

Kim (op. cit.) também explora a questão dos benefícios e afirma que a computação em nuvem oferece quatro importantes deles aos seus consumidores:

- Redução de investimento e custeio:

- Os provedores são os proprietários e gerenciam todos os recursos computacionais, cabendo aos consumidores unicamente conectarem-se às nuvens;

- Neste contexto, os consumidores não necessitam aportar recursos de monta para dar início à sua operação de TI, nem tampouco prover espaço físico para instalações ou arcar com custos de consumo de eletricidade, manutenção de facilidades e remuneração de pessoal especializado.

- Escalabilidade dinâmica:

- Os consumidores podem aumentar ou reduzir o nível de utilização de recursos computacionais de modo fácil e com flexibilidade.

- Menor preço relativo:

- Em geral, o custo dos serviços na computação em nuvem são inferiores aos dispêndios demandados por uma operação própria, pois os consumidores pagam apenas pelos recursos efetivamente utilizados, sem a necessidade de manter uma parcela de capacidade ociosa para fazer frente a situações de pico.

- Facilidade de acesso:

- Pode-se acessar as nuvens e demandar serviços a qualquer momento e de qualquer lugar. 
Smith (op. cit.) é outro autor que também relaciona um conjunto de benefícios que podem ser propiciados pela computação em nuvem aos seus consumidores:

- Escalabilidade dinâmica:

- Os consumidores podem provisionar recursos computacionais na medida em que se fazem necessários; portanto, se as demandas dos seus usuários crescem ou diminuem, os recursos necessários para atendê-las podem ser adicionados ou subtraídos de pronto, em muitos casos até mesmo sem a necessidade de intervenção do provedor.

- Inversões com fundos operacionais:

- Os recursos computacionais disponibilizados nas nuvens podem ser adquiridos com fundos destinados a despesas operacionais ou de custeio, ao invés de com inversões de capital;

- Muitas áreas de TI enfrentam longos processos de aprovação para inversões de capital, porém a aprovação de orçamentos operacionais, via de regra, é mais simples e menos demorada.

- Disponibilização imediata de recursos:

- A computação em nuvem possibilita o provisionamento e a aquisição de recursos em tempo real, para utilização imediata;

- Em termos práticos, significa que não há demora significativa para que os recursos se tornem utilizáveis.

- Menor mobilização de recursos de pessoal e infra-estrutura:

- Como os equipamentos não necessitam ser instalados nas dependências das empresas usuárias, não são requeridas atualizações em sistemas elétricos, alocação de espaço físico, modificações em sistemas de refrigeração e outras assemelhadas;

- Também diminui a demanda por ampliação do quadro de pessoal alocado à TI, quer sejam profissionais contratados quer sejam terceiros.

- Ganhos decorrentes da competição:

- Sempre é possível encontrar um provedor alternativo para um dado serviço; portanto, se um determinado provedor não está desempenhando a contento e/ou seus preços se tornam caros em demasia, os serviços envolvidos podem ser transferidos para outro provedor. 
Qian et al. (op. cit.) citam três benefícios que podem ser obtidos com a computação em nuvem e os apresentam resumidamente:

- Satisfação de requisitos de negócio sob demanda, por meio do redimensionamento dinâmico dos recursos de computação demandados em função de alterações nestes requisitos;

- Redução de custo e economia de energia, face ao emprego de microcomputadores de baixo preço e baixo consumo de energia e da virtualização de servidores;

- Aumento da eficiência na gestão de recursos, por meio da programação dinâmica dos recursos envolvidos.

Comparando estas listas de benefícios oferecidas por quatro diferentes autores, verifica-se que, dos 17 benefícios citados no total, alguns deles o estão de forma repetida - a escalabilidade é citada pelos quatro autores, a redução de custos por três deles e a redução de investimentos iniciais e a inversão com fundos operacionais por dois deles. A facilidade de acesso às nuvens, conforme descrita por Kim (op. cit.), é equivalente, por sua vez, à disponibilização de recursos mencionada por Smith (op. cit.). Dessa forma, pode-se afirmar que se está diante de um elenco de apenas nove benefícios potenciais efetivamente distintos, os quais estão relacionados e descritos no Quadro 4.

Quadro 4 - Benefícios Potenciais Associados à Computação em Nuvem

\begin{tabular}{ll}
\hline Benefício & Descrição \\
\hline \hline Redução de custo & $\begin{array}{l}\text { A computação em nuvem possibilita a redução dos custos globais com TI, } \\
\text { em particular devido ao fato de o custo dos serviços serem inferiores aos } \\
\text { dispêndios demandados por uma operação própria }\end{array}$ \\
\hline $\begin{array}{l}\text { Redução do investimento } \\
\text { inicial }\end{array}$ & $\begin{array}{l}\text { A adoção da computação em nuvem leva à redução do investimento inicial } \\
\text { em TI, tendo em vista que os recursos são de propriedade de terceiros }\end{array}$ \\
\hline Escalabilidade & $\begin{array}{l}\text { A computação em nuvem possibilita que os recursos de TI necessários sejam } \\
\text { escalados dinamicamente, proporcionando flexibilidade }\end{array}$ \\
\hline Acesso a inovações & $\begin{array}{l}\text { A computação em nuvem contribui para a redução de barreiras à inovação e } \\
\text { torna viável utilizar novos tipos de aplicativos e serviços não possíveis em } \\
\text { outras condições }\end{array}$ \\
\hline $\begin{array}{l}\text { Inversões com fundos } \\
\text { operacionais }\end{array}$ & $\begin{array}{l}\text { Os recursos disponibilizados nas nuvens podem ser adquiridos com fundos } \\
\text { destinados a despesas operacionais, ao invés de com inversões de capital }\end{array}$ \\
\hline $\begin{array}{l}\text { Disponibilidade imediata } \\
\text { de recursos }\end{array}$ & $\begin{array}{l}\text { A computação em nuvem possibilita o provisionamento e a aquisição de } \\
\text { recursos em tempo real, de qualquer lugar e para utilização imediata, } \\
\text { conferindo maior disponibilidade a esses recursos e viabilizando, dessa } \\
\text { forma, a implantação mais rápida de serviços }\end{array}$ \\
\hline
\end{tabular}


Quadro 4 - Benefícios Potenciais Associados à Computação em Nuvem (cont.)

\begin{tabular}{ll}
\hline Benefício & Descrição \\
\hline \hline $\begin{array}{l}\text { Menor mobilização de } \\
\text { recursos destinados a TI }\end{array}$ & $\begin{array}{l}\text { A computação em nuvem propicia menor mobilização de recursos de pessoal } \\
\text { e infra-estrutura para TI }\end{array}$ \\
\hline $\begin{array}{l}\text { Ganhos decorrentes da } \\
\text { competição }\end{array}$ & $\begin{array}{l}\text { Se um determinado provedor passa a não desempenhar a contento e/ou seus } \\
\text { preços se elevam em demasia, os serviços envolvidos podem ser transferidos } \\
\text { para outro provedor }\end{array}$ \\
\hline Gestão de recursos & $\begin{array}{l}\text { A computação em nuvem propicia maior eficiência na gestão dos recursos de } \\
\text { TI, por meio da sua programação dinâmica }\end{array}$ \\
\hline
\end{tabular}

\subsubsection{Barreiras Potenciais Inibidoras da Adoção da Computação em Nuvem}

As referências bibliográficas consultadas dão pouco destaque à questão das barreiras que podem servir de impedimento à contratação de serviços em ambientes de computação em nuvem.

Miller (2008) é um dos poucos autores que relaciona uma lista de barreiras potenciais que podem inibir a migração de consumidores para estes ambientes. As barreiras por ele citadas e que podem ser atribuídas à atuação dos fornecedores de serviços por meio de nuvens não privadas são:

- Falta de capacidade técnica:

- Implementar um ambiente de computação em nuvem é, por si só, um enorme desafio técnico;

- Centenas ou milhares de computadores e servidores devem ser adquiridos, instalados com algum grau de interação e ter sua utilização gerenciada; além disso, soluções complexas de software têm que ser desenvolvidas e disponibilizadas em regime $24 \times 7$;

- Tudo isto requer um volume significativo de recursos e não é qualquer empresa que consegue viabilizá-los adequadamente.

- Deficiência do modelo de negócio:

- Dados os volumes de investimento necessários para implementar um ambiente de computação em nuvem, os meios para recuperar o capital investido e gerar lucros tornam estas operações verdadeiros desafios para os interessados em prestar este tipo de serviços;

- A eventual incapacidade para prosperar e prosseguir na atividade é um fator que pode inibir a disposição dos consumidores em aderir a este modelo de negócio. 
- Falhas de segurança:

- Esta questão diz respeito aos dados mantidos pelas aplicações executadas em nuvens;

- São tantos os casos de violação de segurança em ambientes com menor grau de vulnerabilidade, que os consumidores questionam se, de fato, os fornecedores têm condições de garantir a segurança nas nuvens.

- Tradição comportamental:

- Muitos consumidores não confiam em algo que não podem ver ou tocar, pois isto lhes trás à tona uma sensação de perda; é o que ocorre quando seus acervos de informação têm a perspectiva de serem transferidos para ambientes de nuvem e passarem a ser armazenados em locais distantes ou mesmo desconhecidos;

- Uma mudança de atitude para com relação a esta sensação exige novo posicionamento por parte dos consumidores e representa um novo paradigma, difícil de ser aceito.

Marks e Lozano (2010) também exploram a questão das barreiras à adoção da computação em nuvem e destacam o que se faz necessário, por parte de um determinado fornecedor, para buscar satisfazer aos consumidores:

- Segurança e privacidade:

- A segurança e a privacidade são quesitos mandatórios nos ambientes de computação em nuvem e a perspectiva de poder se defrontar com falhas de segurança e/ou violação da privacidade têm levado os consumidores a questionar a adoção desses ambientes, em particular no que se refere a serviços afetos a aspectos de importância crítica para seus negócios.

- Governança, acordos de nível de serviço e qualidade:

- Estes quesitos compõem um importante nicho de obstáculos potenciais;

- Os consumidores receiam que os fornecedores, dados a complexidade, ineditismo e consequente pouco tempo de maturação destes temas, não estejam preparados para tratálos de forma satisfatória e que isto possa provocar dificuldades no relacionamento.

- Confiabilidade:

- Os consumidores esperam que os ambientes de computação em nuvem sejam confiáveis e que a disponibilidade dos serviços e recursos oferecidos nas nuvens atenda na íntegra às suas necessidades, em especial àquelas relacionadas a aspectos críticos dos negócios; 
- A computação em nuvem depende, fundamentalmente, de confiabilidade e, se os consumidores sentem que não podem tê-la na plenitude, relutam em aderir a este modelo de serviços.

Comparando estas duas listas de barreiras, verifica-se que, das sete citadas no total, as duas primeiras mencionadas por Marks e Lozano (op. cit.) admitem desdobramentos em quesitos independentes: a primeira, segregando a segurança da privacidade e, a outra, separando governança, acordos de nível de serviço e qualidade. Além disso, o quesito segurança está citado de forma repetida por ambos os autores. Em assim sendo, pode-se afirmar que se está diante de um total de nove barreiras efetivamente distintas, as quais estão relacionadas e descritas no Quadro 5.

Quadro 5 - Barreiras Potenciais Inibidoras da Adoção da Computação em Nuvem

\begin{tabular}{|c|c|}
\hline Barreira & Descrição \\
\hline $\begin{array}{l}\text { Falta de capacidade } \\
\text { técnica }\end{array}$ & $\begin{array}{l}\text { Os ambientes de computação em nuvem têm um alto grau de complexidade, o que } \\
\text { exige um grau também elevado de capacidade técnica para sua estruturação e } \\
\text { operação, o que leva os consumidores a questionar se os provedores estão, de fato, } \\
\text { preparados para tal desafio }\end{array}$ \\
\hline $\begin{array}{l}\text { Deficiência do } \\
\text { modelo de negócio }\end{array}$ & $\begin{array}{l}\text { O modelo de negócio da computação em nuvem, por exigir investimentos iniciais } \\
\text { elevados, demanda grande competência de gestão para garantir rentabilidade e } \\
\text { retorno sobre o capital investido, o que gera desconfianças, da parte dos } \\
\text { consumidores, quanto à capacidade dos provedores em ser bem sucedidos }\end{array}$ \\
\hline segurança & $\begin{array}{l}\text { A perspectiva de poder se defrontar com falhas de segurança que comprometam } \\
\text { suas operações é uma questão crítica para os consumidores e tem contribuído para } \\
\text { levá-los a questionar contratação de serviços em ambientes de nuvem }\end{array}$ \\
\hline Privacidade & $\begin{array}{l}\text { A perspectiva de poder se defrontar com violação da sua privacidade é outra } \\
\text { questão crítica para os consumidores e também tem contribuído para levá-los a } \\
\text { questionar a adoção da computação em nuvem }\end{array}$ \\
\hline $\begin{array}{l}\text { Tradição } \\
\text { comportamental }\end{array}$ & $\begin{array}{l}\text { Os consumidores mostram-se desconfiados perante o fato de não saberem onde e } \\
\text { de que forma seus acervos de informação estão sendo guardados e manipulados }\end{array}$ \\
\hline Governança & $\begin{array}{l}\text { A potencial falta de maturidade do modelo de governança é uma questão que tem } \\
\text { preocupado os consumidores, que não se sentem confortáveis quanto à capacidade } \\
\text { dos provedores em gerir satisfatoriamente ambientes complexos como os de } \\
\text { computação em nuvem }\end{array}$ \\
\hline $\begin{array}{l}\text { Acordos de nível de } \\
\text { serviço }\end{array}$ & $\begin{array}{l}\text { A pouca experiência dos provedores na prestação de serviços em ambientes de } \\
\text { nuvem levanta dúvidas quanto à sua capacidade para honrar os acordos de nível de } \\
\text { serviço, os quais poderiam tender a ser simples tópicos contratuais sem valor } \\
\text { prático }\end{array}$ \\
\hline Qualidade & $\begin{array}{l}\text { A complexidade dos ambientes de nuvem é um fator que pode limitar o nível de } \\
\text { qualidade dos serviços prestados }\end{array}$ \\
\hline Confiabilidade & $\begin{array}{l}\text { A computação em nuvem depende de confiabilidade e, se os consumidores sentem } \\
\text { que não podem tê-la na plenitude, relutam em aderir a este modelo de serviços }\end{array}$ \\
\hline
\end{tabular}




\subsection{Risco e Gestão de Riscos}

Este tópico trata do risco em três níveis distintos: (a) o risco de uma forma geral, amplo e sem especificidades, (b) o risco associado à TI e (c) o risco associado especificamente à utilização da TI em ambientes de computação em nuvem. São abordados os conceitos de risco e de gestão de riscos, as características particulares do risco em cada um dos três níveis e sistemáticas para gestão de riscos.

\subsubsection{Definições para Risco}

Uma definição que retrata de forma adequada o entendimento sobre risco existente ao final do século passado é a proposta por Ewald (1991, p. 199), para quem: "[...] 'risco' é entendido como sinônimo de ameaça ou perigo, em face de algum evento desfavorável que possa afetar alguém; designa uma ameaça efetiva". ${ }^{3}$

Neste contexto, o risco está também associado à segurança. Para ilustrar esta associação, Bitsch (2001, p. 179) recorre à norma alemã relativa à segurança (DIN-VDE-31000) e oferece um diagrama explicativo (vide Figura 6) da denominada "situação de segurança", por ele definida como: "[...] uma situação na qual o risco [efetivo] é menor do que o risco máximo aceitável". 4

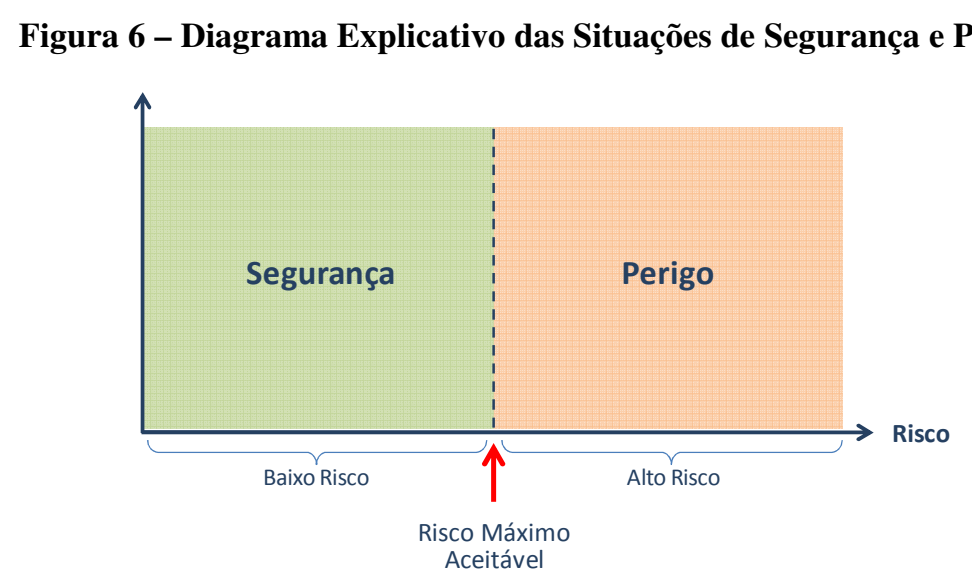

FONTE: Adaptado de BITSCH, 2001; p. 179.

\footnotetext{
3 "[...] 'risk' is understood as a synonym for danger or peril, for some unhappy event which may happen to someone; it designates an objective threat."

4 "[...] a situation in which the risk is lower than the maximum acceptable risk".
} 
Conforme mostra a figura, caso o risco efetivo se situe acima de um limite estabelecido como máximo, a situação deixa de ser de segurança para se tornar de perigo ou passível da ocorrência de acidentes.

Segurança pode ser definida como uma situação de ausência de acidentes, onde, por acidente, entende-se um evento que implica numa perda não planejada e inaceitável. A segurança, diferentemente da confiabilidade, é uma propriedade de um todo, não de uma parte ou componente desse todo. Por exemplo, não é possível determinar se uma usina nuclear tem segurança aceitável examinando apenas uma de suas válvulas; quaisquer considerações acerca da segurança dessa válvula, sem a informação relativa ao contexto em que ela é utilizada, não tem significado efetivo. Na realidade, pode-se até concluir sobre a confiabilidade da válvula, mas a segurança somente pode ser determinada analisando o relacionamento entre ela e os demais componentes e partes da usina, ou seja, no contexto do todo (LEVESON, 2011).

Dependendo da particular situação ou contexto, a definição de segurança pode variar significativamente. Por exemplo, o United States Department of Defense (2000, p. 2) define uma situação de segurança de uma forma mais ampla, por meio da seguinte frase: "Livre de condições que podem causar morte, ferimento, doença ocupacional, dano ou perda de equipamento ou propriedade, ou dano ao ambiente." 5

Do mesmo modo que na presença de acidentes não é possível haver segurança, esta também não existe naturalmente em situações de incerteza. Na incerteza, a segurança necessita ser produzida, o que pode ser conseguido por meio da gestão de riscos (WENGER et al., 2008).

O conceito de risco evoluiu ao longo das últimas duas décadas e seu foco ampliou-se, para passar a considerar não apenas a questão das ameaças, mas também os benefícios potenciais. Em sua publicação mais recente sobre este tema, a International Organization for Standardization, ISO, (2009, p. 1) coloca que: "Risco é o efeito da incerteza sobre os objetivos." 6

\footnotetext{
5 "Freedom from those conditions that cause death, injury, occupational illness, damage to or loss of equipment or property, or damage to the environment."

6 "Risk: effect of uncertainty on objectives."
} 
A ISO explicita que o efeito deve ser entendido como um desvio positivo ou negativo (grifo nosso) para com relação a uma situação esperada e a incerteza, por sua vez, é apresentada como um estado de insuficiência de informações relativas ao entendimento ou conhecimento de um evento, suas consequências e probabilidade de ocorrência.

Ainda no que diz respeito à incerteza, o Committee of Sponsoring Organizations of the Treadway Commission, COSO, explora esta questão sinalizando que todas as organizações, em algum momento, acabam por enfrentar incertezas e que o desafio que a elas se coloca é determinar qual o grau de incerteza que estão dispostas a aceitar, de modo a não prejudicar o objetivo de adicionar valor aos stakeholders. A incerteza, em si, não é prejudicial, dado que pode trazer no seu bojo tanto riscos quanto oportunidades, o que, potencialmente, pode implicar não somente em erosão, mas em aumento do valor (COSO, 2004).

Wenger et al. (op. cit., p. 5) também abordam a questão e colocam que:

"Riscos são indiretos, não premeditados, incertos e, por definição, localizados no futuro, uma vez que apenas se materializam quando se manifestam como eventos efetivos; em outras palavras: a essência do risco não é estar acontecendo, mas poder acontecer." ${ }^{7}$

Habegger (2008) sustenta que a eliminação dos riscos por completo não é viável, nem tampouco desejável, devido a, pelo menos, três motivos: (a) não há meios para as pessoas controlarem o futuro, (b) os recursos disponíveis para lidar com riscos são sempre limitados e (c) aceitar riscos está no núcleo do processo de inovação e é uma condição mandatória para o crescimento econômico e o progresso social.

\subsubsection{Definições e Roteiros para Gestão de Riscos}

O desafio de direcionar, com prudência e sucesso, o curso dos riscos por entre oportunidades e ameaças acabou por motivar a instituição da gestão de riscos, disciplina cujo objetivo é encontrar caminhos e abordagens que permitam detectar riscos em tempo hábil, avaliar ameaças futuras adequadamente e estruturar e implementar ações bem sucedidas de mitigação (Ibid.).

\footnotetext{
7 "Risks are indirect, unintended, uncertain, and are by definition situated in the future, since they only materialize when they are manifested as real events. In other words: the essence of risk is not that it is happening, but that it might happen."
} 
De uma maneira mais genérica, a ISO (op. cit., p. 2) coloca que: "Gestão de riscos [é o conjunto de] atividades estruturadas que visam direcionar e controlar [as ações de] uma organização no que se refere ao risco." 8

A gestão de riscos deve: (a) fazer parte integral do escopo da gestão, (b) estar integrada à cultura e às práticas e (c) ser adaptada aos processos de negócio (Ibid.).

Crouhy et al. (2006) argumentam que a gestão de riscos diz respeito a como as organizações selecionam o tipo e o grau dos riscos que são apropriados ao seu perfil e que se dispõem a assumir. Para Wenger et al. (op. cit.), a implementação de uma gestão de riscos efetiva requer um perfeito entendimento das características e da dinâmica dos riscos e das vulnerabilidades do ambiente.

Na visão de Kliem (2000), a gestão de riscos é composta por três etapas: identificação, análise e controle. Para Habegger (op. cit.), também são três as etapas da gestão de riscos, porém com denominação diferente: identificação, mensuração e mitigação; apesar da diferença de nomenclatura, a essência das etapas deste roteiro é praticamente a mesma que a do de Kliem (op. cit.).

Raz e Hillson (2005) são outros autores a sugerir um roteiro para gerir riscos, este composto por quatro etapas: planejamento, identificação, análise e tratamento. A novidade desta proposta é a primeira etapa, dado que as três últimas, em termos de conteúdo, são semelhantes às dos dois roteiros acima apresentados.

Já Crouhy et al. (op. cit.) propõem um roteiro mais elaborado para a gestão de riscos, envolvendo um número maior de etapas, porém pouco diferindo em termos de conceitos e produtos. A Figura 7 apresenta uma representação gráfica deste roteiro, que compreende sete etapas e aborda explicitamente a questão da estratégia frente ao risco.

\footnotetext{
8 "Risk management: coordinated activities to direct and control an organization with regard to risk."
} 
Figura 7 - Roteiro para Gestão de Riscos

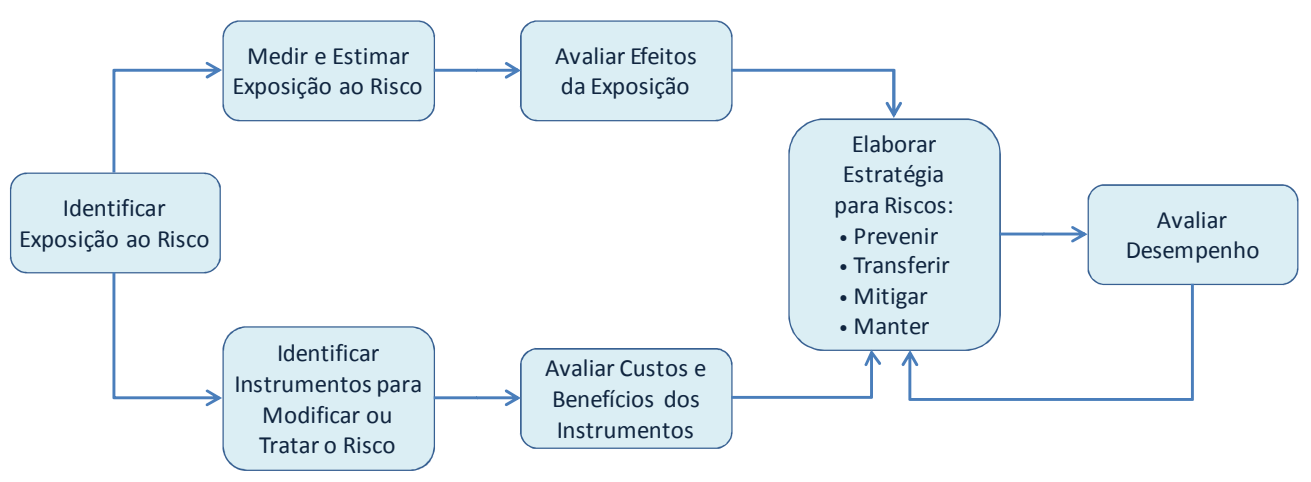

FONTE: Adaptado de CROUHY et al., 2006; p. 2.

A ISO (op. cit.) propõe um roteiro bastante mais completo para a gestão de riscos, compreendendo não apenas o processo de gestão em si, mas também seu entorno, isto é, a maneira pela qual este processo deve ser construído e inserido no contexto da organização. Uma visão esquemática do modelo da ISO está apresentada na Figura 8.

Figura 8 - Modelo Ampliado para Gestão de Riscos

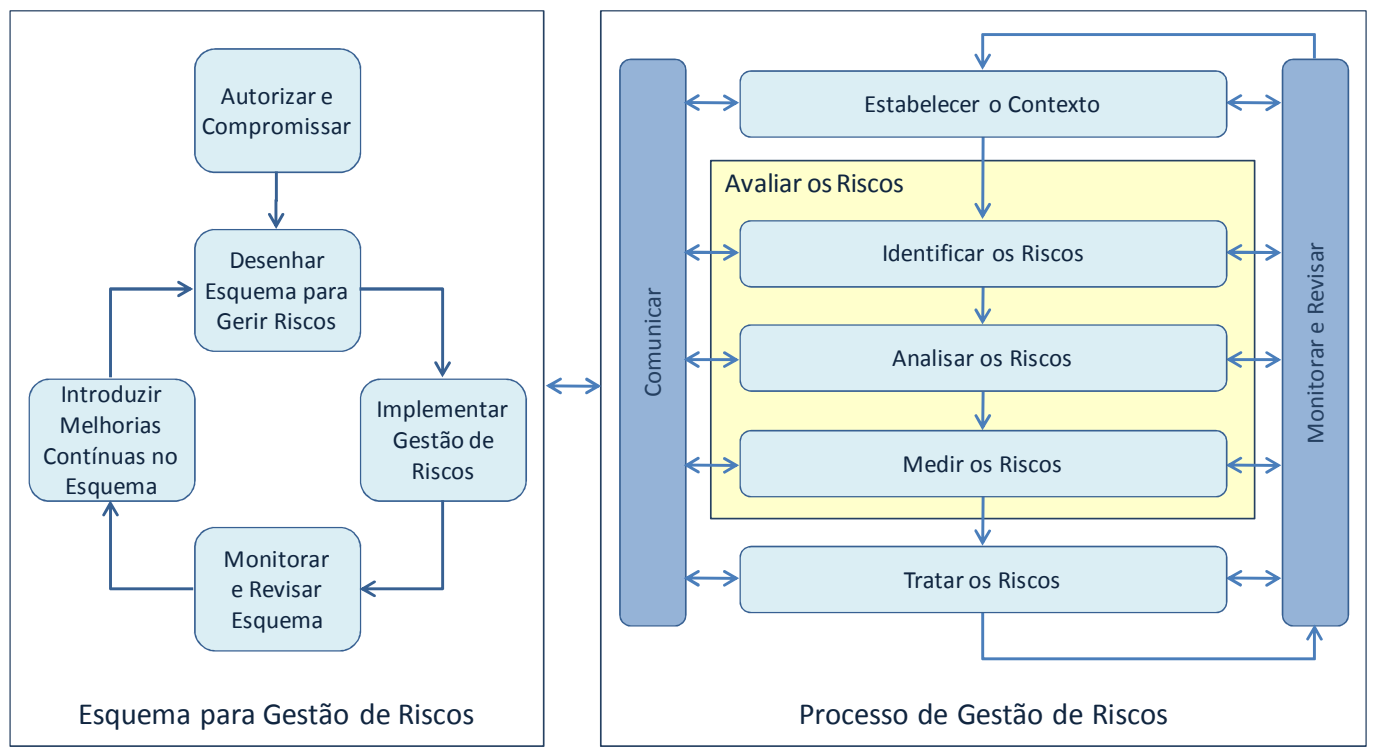

FONTE: Adaptado de ISO, 2009; p. vii.

Para fins de exploração das etapas da gestão de riscos em maior grau de detalhe, escolheu-se, dentre os cinco roteiros apresentados neste tópico, aquele proposto por Habegger (op. cit.), entendendo, primeiramente, não ser necessário recorrer a um roteiro mais sofisticado para 
ilustrar o tema e, em segundo lugar, por ele ser, dentre os dois mais simples, o melhor explicado por seu autor. Este esquema compreende:

- Etapa 1 - Identificar os riscos:

- O aspecto crítico nesta etapa é a disponibilidade de informações; obter e processar informações são condições mandatórias para o descobrimento de problemas;

- O acúmulo de informações gera evidências mais estruturadas e explícitas acerca de eventuais mudanças no ambiente e o desafio é ampliar o escopo das fontes disponíveis, acessá-las oportunamente e utilizar as informações obtidas da maneira mais criativa possível;

- A evolução da TI é um elemento facilitador deste processo, à medida que as informações se tornam mais disponíveis e facilmente acessáveis; porém, não se deve deixar de considerar o lado negativo desta questão, pois uma maior quantidade de informações torna mais difícil a filtragem e seleção daquelas que são, de fato, relevantes.

- Etapa 2 - Mensurar os riscos:

- Esta etapa compreende três atividades: estruturação, avaliação e priorização dos riscos; estas atividades ocorrem em ciclos, no bojo de um processo que visa facilitar a obtenção de consenso entre os diversos envolvidos;

- A estruturação dos riscos busca aportar uma ordem ao universo dos riscos identificados, introduzindo categorias nas quais estes possam ser classificados e possibilitando aos analistas de risco subdividi-los da maneira mais conveniente;

- A avaliação dos riscos visa explicitar a importância relativa entre as distintas categorias nas quais os riscos foram dispostos; muito embora deva refletir visões objetivas no que diz respeito a aspectos tais como comportamento, evolução, potencial de dano e probabilidade de ocorrência dos riscos, esta atividade nem sempre é realizada com a adequada exclusão de fatores subjetivos;

- A priorização dos riscos objetiva destacar aqueles que devem merecer maior grau de atenção, em decorrência da sua magnitude potencial e dado que os recursos destinados à mitigação, via de regra, não são suficientes, por questões de ordem prática de benefícios versus custo, para permitir que todos os riscos sejam evitados.

- Etapa 3 - Mitigar os riscos:

- Uma vez tido sido identificados, estruturados, avaliados e priorizados, os riscos considerados mais significativos devem ser objeto de ações de mitigação; 
- Estas ações enquadram-se em duas distintas estratégias: preventiva e corretiva; a estratégia preventiva visa evitar a ocorrência de eventos adversos e, com isso, eliminar as causas de particulares riscos; a estratégia corretiva destina-se a minimizar os efeitos da ocorrência de eventos que geram exposição a riscos; evidentemente, estas duas estratégias são complementares e devem ser estabelecidas em conjunto;

- Em termos práticos, pode-se considerar que é impossível eliminar por completo um determinado risco, por conta da necessidade de se dispor tanto de um controle absoluto da situação quanto de recursos muito acima de limites razoáveis, que tenderiam a desequilibrar a relação benefício/custo;

- Adicionalmente, é importante considerar que aos riscos também se associam oportunidades, o que faz com que possa não ser de todo conveniente eliminá-los por completo, pois essas oportunidades potenciais deixariam de ser aproveitáveis; portanto, no mundo real, o objetivo das ações de mitigação não deve ser eliminar por completo todos os riscos, mas procurar mantê-los num patamar adequado;

- Por fim, não deve ser descartada a possibilidade de, no rol das ações de mitigação, serem incluídos instrumentos para transferir riscos a terceiros, quando esta possibilidade se fizer factível.

O processo acima apresentado trata de uma abordagem genérica para gestão de riscos e deve ser adaptado a cada situação e realidade específicas para poder ser adequadamente aplicado (Ibid.).

Mais recentemente, passou-se a considerar a gestão de risco também em nível corporativo ou empresarial, o que levou à instituição da disciplina de mesmo nome. Nesta linha, por exemplo, o COSO (op. cit., p. 2), define a gestão empresarial de riscos como:

"[...] um processo, conduzido pelo corpo de diretores, gerentes e outros profissionais de uma organização, aplicado com vistas a estabelecer uma estratégia ampla, destinada a identificar potenciais eventos que possam afetar a organização e gerenciar riscos que se enquadrem no seu perfil, no sentido de prover um grau razoável de garantia quanto ao alcance dos objetivos organizacionais." 9

\footnotetext{
9 "[...] a process, effected by an entity's board of directors, management and other personnel, applied in strategy setting and across the enterprise, designed to identify potential events that may affect the entity, and manage risk to be within its risk appetite, to provide reasonable assurance regarding the achievement of entity objectives."
} 
A gestão empresarial de riscos permite aos gestores de uma organização lidar de forma efetiva com as incertezas e com os riscos e oportunidades a elas associados, ampliando a capacidade de se criar valor para a organização (Ibid.).

\subsubsection{Riscos Inerentes à TI e Gestão de Riscos em TI}

Risco da TI é a possibilidade de que algum evento imprevisto, que envolva falha ou mau uso da TI, ameace um objetivo empresarial. Na realidade atual, este tipo de riscos já não se limita à área de TI ou ao data center (WESTERMAN e HUNTER, 2007).

Para estes autores (ibid.), a maioria dos riscos da TI não decorre de problemas técnicos ou gerados por funcionários de baixo escalão, mas sim de falhas de supervisão e da governança de TI; ou seja, a maior parte destes riscos não resulta da tecnologia em si, mas de processos decisórios que, de modo consciente ou não, ignoram as possíveis consequências destes riscos para os negócios. Assim, as causas que levam aos riscos da TI são:

- Governança de TI ineficaz:

- Decorre da ausência de estruturas e processos apropriados para um amplo envolvimento de todas as áreas de uma organização nos investimentos e nas decisões relativos à TI;

- Acaba por levar a decisões otimizadas localmente, mas que geram riscos empresariais; sem o envolvimento das áreas de negócios, os gestores da TI podem fazer pressuposições incorretas a respeito de quais riscos impactam mais os negócios.

- Complexidade descontrolada:

- A complexidade por si só não é necessariamente mais arriscada do que a simplicidade; entretanto, a complexidade sem uma engenharia sólida a sustentá-la aumenta o risco de diversas maneiras, pois os ambientes tendem a ser frágeis.

- Falta de atenção ao risco:

- A falta de atenção aumenta os riscos operacionais; seus sintomas podem incluir: (a) falta de conhecimento ou conhecimento inadequado, (b) má gestão da infra-estrutura, (c) ignorância, negligência ou deslealdade dos funcionários e (d) mecanismos de controle insensíveis a atividades perigosas.

Como uma forma de lidar com os riscos da TI, estes autores (ibid.) introduzem dois conceitos: o "Esquema 4A" e as "Disciplinas Focais de Gestão dos Riscos da TI". 
$\mathrm{O}$ "Esquema 4A" 10 compreende um elenco de quatro fatores de risco associados, um a um, a quatro objetivos de negócios da TI relacionados aos riscos - disponibilidade, acesso, precisão e agilidade, objetivos estes que podem ser assim descritos (Ibid.):

- Disponibilidade:

- Manter os sistemas e os processos de negócio por eles suportados em operação e recuperá-los em caso de interrupções.

- Acesso:

- Assegurar o acesso adequado a dados e sistemas, de modo que as pessoas certas o tenham quando necessário e as pessoas erradas, não.

- Precisão:

- Prover informações corretas, oportunas e completas, que satisfaçam aos requisitos da administração, dos funcionários, clientes, fornecedores e órgãos reguladores.

- Agilidade:

- Possuir a capacidade de mudar com custos controlados e rapidez.

Os autores (ibid.) afirmam que os fatores de risco por eles apresentados formam uma hierarquia, à qual denominam "pirâmide dos riscos da TI" e que está graficamente representada na Figura 9.

Figura 9 - Pirâmide dos Riscos da TI

\begin{tabular}{|c|c|c|}
\hline \multicolumn{2}{|c|}{$\begin{array}{l}\text { - Relações ruins entre negócios e TIC } \\
\text { - Mau cumprimento de projetos }\end{array}$} & \multirow[t]{2}{*}{ Agilidade } \\
\hline \multicolumn{2}{|c|}{$\begin{array}{l}\text { - Aplicações não atendem aos requisitos de negócio } \\
\text { - Necessidade de integração manual de dados } \\
\text { - Implementações significativas em progresso ou recém-concluídas }\end{array}$} & \\
\hline $\begin{array}{l}\text { - Dados não compartimentados } \\
\text { - Aplicações requerem padronização }\end{array}$ & $\begin{array}{l}\text { - Falta de controle interno nas aplicações } \\
\text { - Rede não confiável }\end{array}$ & Acesso \\
\hline $\begin{array}{l}\text { - Alta rotatividade do pessoal de TIC } \\
\text { - Infra-estrutura não padronizada } \\
\text { - Gestão ineficaz de atualizações } \\
\text { - Tecnologia antiga }\end{array}$ & $\begin{array}{l}\text { - Backup e recuperação ruins } \\
\text { - Processos e aplicativos mal entendidos } \\
\text { - Falta de habilidades para novas iniciativas } \\
\text { - Deficiências sob a ótica dos reguladores }\end{array}$ & Disponibilidade \\
\hline
\end{tabular}

FONTE: Adaptado de WESTERMAN e HUNTER, 2007; p. 59.

\footnotetext{
${ }^{10}$ Nota: a denominação "4A" decorre do fato de os fatores, no original em inglês, serem: availability, access, accuracy e agility.
} 
A disposição dos fatores na pirâmide demonstra que o fator posicionado numa determinada camada influencia não apenas os riscos associados a ela, mas também aqueles associados às camadas superiores.

O segundo conceito, as "Disciplinas Focais de Gestão dos Riscos da TI", compreende três tópicos: (a) alicerce de TI, (b) governança dos riscos da TI e (c) cultura de consciência dos riscos da TI, os quais podem ser assim delimitados (Ibid.):

- Alicerce de TI:

- Um alicerce de TI é o conjunto de ativos, procedimentos e pessoal de TI que sustentam os processos de negócio e a tomada de decisões;

- Um alicerce de TI sólido é bem compreendido, bem administrado e não mais complexo do que o necessário;

- Um alicerce sólido de TI é resistente a riscos de muitas maneiras: (a) problemas são menos prováveis, (b) quando problemas e falhas ocorrem, são mais rápida e facilmente diagnosticados e reparados, (c) estimar riscos torna-se mais fácil e (d) torna-se mais fácil fazer manutenções e implementar mudanças.

- Governança dos Riscos da TI:

- A governança dos riscos da TI é o conjunto de processos, políticas e estruturas que proporcionam uma visão em nível empresarial de todos os riscos, de maneira tal que os executivos podem priorizar e investir adequadamente na gestão desses riscos, ao mesmo tempo em que gerentes de menor nível podem gerir a maioria dos riscos em suas áreas;

- A governança dos riscos da TI compreende as etapas indicadas na Figura 10.

Figura 10 - Etapas da Governança dos Riscos da TI

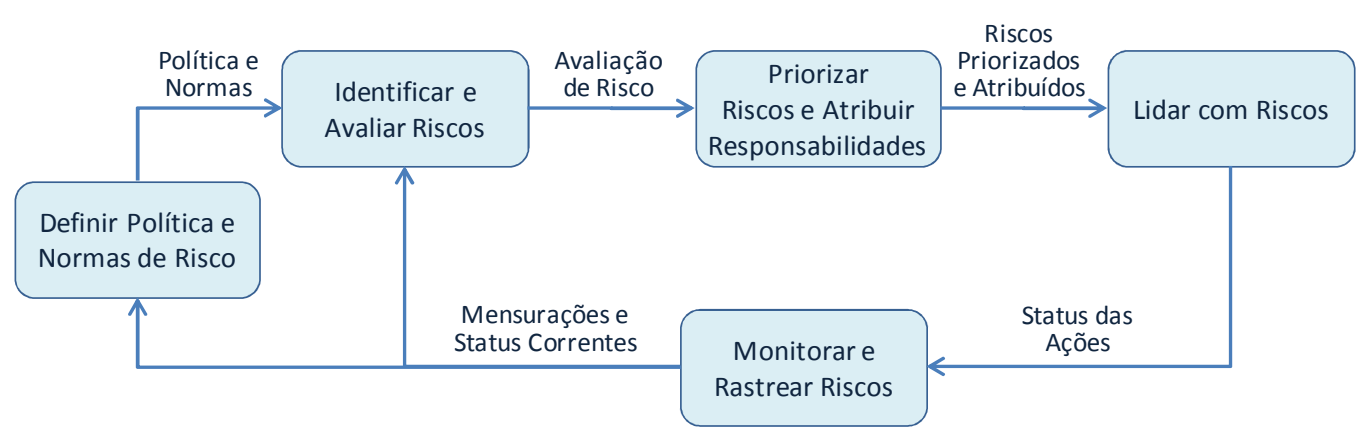

FONTE: Adaptado de WESTERMAN e HUNTER, 2007; p. 117. 
- Cultura de Consciência dos Riscos da TI:

- Esta disciplina leva uma organização a um patamar no qual todas as pessoas, em todos os níveis, estão cientes dos riscos, discutem-nos e assumem a responsabilidade pessoal por administrá-los;

- Organizações conscientes do risco desenvolvem uma consciência generalizada acerca da natureza e das consequências do comportamento arriscado e estimulam a criação de uma cultura em que o risco é discutido e gerido abertamente.

Para cada disciplina focal de gestão dos riscos da TI, os autores (ibid.) citam um rol de quesitos que sinalizam o grau em que a disciplina é conduzida. O grau de competência indica que a disciplina é aplicada de forma correta, porém com intensidade mediana; já o grau de excelência indica que ela é aplicada não só de forma correta, mas também com intensidade acima da média. O Quadro 6 exibe um resumo destes quesitos.

Quadro 6 - Graus de Qualificação das Disciplinas Focais de Gestão dos Riscos da TI

\begin{tabular}{|c|c|c|}
\hline Disciplina & Grau de Competência & Grau de Excelência \\
\hline Alicerce & $\begin{array}{l}\text { - Há proteções básicas contra ataques } \\
\text { - Há um plano de continuidade para os negócios, } \\
\text { testado e atualizado com regularidade } \\
\text { - Existe um processo capaz de gerir ativos e } \\
\text { operações de TI, apoiado por um sólido } \\
\text { monitoramento } \\
\text { - Há uma arquitetura empresarial e tecnológica, } \\
\text { base para novos desenvolvimentos e planos } \\
\text { - Existe e é seguido um plano para renovar e/ou } \\
\text { eliminar aplicativos e componentes da infra- } \\
\text { estrutura complexos }\end{array}$ & $\begin{array}{l}\text { - A arquitetura foi implantada à risca } \\
\text { e há esforços contínuos para } \\
\text { simplificar o alicerce } \\
\text { - Há uma renovação sistemática e } \\
\text { incremental e uma ampliação } \\
\text { cuidadosa do alicerce simplificado } \\
\text { - São continuamente investigadas } \\
\text { tecnologias avançadas, com } \\
\text { potencial para tornar obsoleta a } \\
\text { base instalada ou para permitir um } \\
\text { salto à frente da concorrência }\end{array}$ \\
\hline Governança & $\begin{array}{l}\text { - Existe um arranjo de governança em múltiplos } \\
\text { níveis; o processo é gerido por uma única pessoa } \\
\text { - Há categorias de risco formalmente } \\
\text { identificadas e documentadas } \\
\text { - Riscos são registrados e rastreados } \\
\text { sistematicamente } \\
\text { - Há um esquema consistente de avaliação dos } \\
\text { riscos, aplicado ao menos uma vez por trimestre } \\
\text { - Foram estabelecidas melhores práticas para a } \\
\text { gestão dos riscos da TI } \\
\text { - Há um processo formal para tratamento de } \\
\text { exceções à política de risco } \\
\text { - Executivos conseguem descrever o processo de } \\
\text { governança dos riscos da TI }\end{array}$ & $\begin{array}{l}\text { - É obrigatório realizar avaliações } \\
\text { dos sistemas existentes e daqueles } \\
\text { em desenvolvimento } \\
\text { - É medida continuamente a } \\
\text { efetividade dos esforços para } \\
\text { redução dos riscos } \\
\text { - A gestão dos riscos de TI é } \\
\text { complementada por avaliações de } \\
\text { novos parceiros e prestadores de } \\
\text { serviço, bem como dos envolvidos } \\
\text { em processos de fusão e aquisições } \\
\text { - Há integração plena entre a gestão } \\
\text { dos riscos de TI e os processos e } \\
\text { órgãos de gestão dos demais riscos }\end{array}$ \\
\hline
\end{tabular}


Quadro 6 - Graus de Qualificação das Disciplinas Focais de Gestão dos Riscos da TI (cont.)

\begin{tabular}{|c|c|c|}
\hline Disciplina & Grau de Competência & Grau de Excelência \\
\hline Consciência & $\begin{array}{l}\text { - Todos os funcionários tratam abertamente a } \\
\text { questão dos riscos } \\
\text { - Discussões sobre risco fazem parte da agenda } \\
\text { dos executivos } \\
\text { - As estimativas utilizadas em projetos são } \\
\text { realistas, seus fatores críticos conhecidos e há } \\
\text { avaliações periódicas do status } \\
\text { - Executivos de TI e de negócios são capazes de } \\
\text { citar os três maiores riscos inerentes às suas } \\
\text { responsabilidades e as ações para mitigá-los } \\
\text { - Todos os funcionários são capazes de citar os } \\
\text { riscos da TI que os afetam }\end{array}$ & $\begin{array}{l}\text { - Há lembretes frequentes sobre os } \\
\text { riscos da TI e sua gestão } \\
\text { - Há treinamento regular sobre os } \\
\text { riscos da TI e controles relevantes } \\
\text { - Há mecanismos efetivos para } \\
\text { reportar incidentes } \\
\text { - Todos os funcionários sentem-se } \\
\text { responsáveis por identificar, lidar } \\
\text { com e prevenir os riscos da TI } \\
\text { - Executivos consideram os riscos da } \\
\text { TI em suas decisões } \\
\text { - Executivos incorporam nos planos } \\
\text { de longo prazo cenários futuros e } \\
\text { seus riscos quanto à TI }\end{array}$ \\
\hline
\end{tabular}

FONTE: Adaptado de WESTERMAN e HUNTER; 2007; p. 164-165.

O Esquema 4A e as Disciplinas Focais de Gestão dos Riscos da TI combinam-se para fornecer a base para a elaboração de estratégias para gestão dos riscos de TI. Esta combinação pode ser visualizada no processo de gestão dos riscos da TI proposto pelos autores (ibid.) e que está graficamente indicado na Figura 11.

Figura 11 - Processo de Gestão dos Riscos da TI

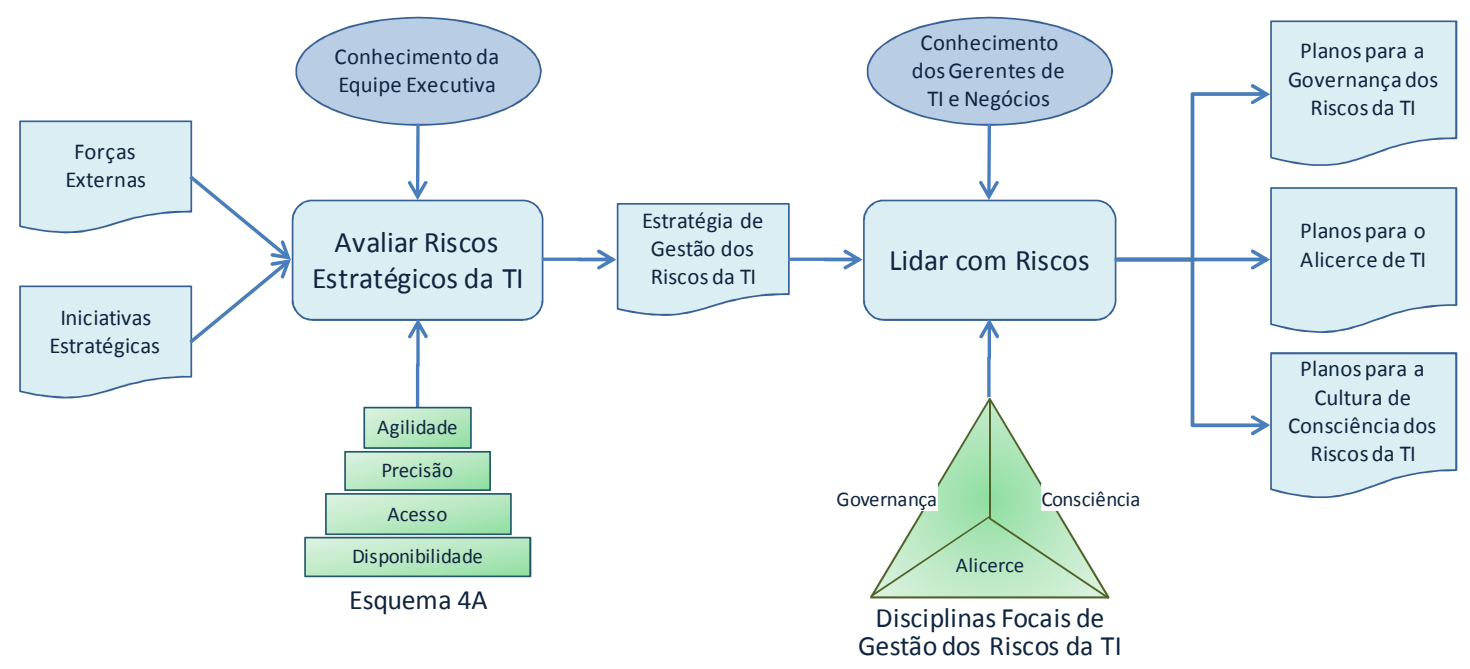

FONTE: Adaptado de WESTERMAN e HUNTER, 2007; p. 184. 


\subsubsection{Riscos Inerentes à Computação em Nuvem}

Vários autores já abordaram a questão dos riscos inerentes à computação em nuvem, existindo, em decorrência, distintas listas que sugerem aspectos a serem considerados relativamente a este tema. Dentre estes autores, foram selecionados cinco para terem suas proposições analisadas em maior grau de detalhe.

Kim (op. cit.) é um dos autores que cita riscos que podem afetar os consumidores de serviços de computação em nuvem:

- Indisponibilidade:

- A prática tem mostrado que a indisponibilidade de serviços oferecidos pelos provedores mais qualificados é extremamente pequena e não é maior do que a obtida nos data centers próprios; em geral, os níveis de serviço pactuados com os consumidores têm sido cumpridos de modo satisfatório;

- Entretanto, mesmo os provedores mais qualificados não estão livres de enfrentarem problemas e verem seus serviços ficar indisponíveis para os consumidores por algum período de tempo; em decorrência, é aconselhável que os consumidores tomem medidas preventivas para estas situações; entre estas medidas, pode-se citar a manutenção de versões atualizadas dos aplicativos em condições de ser executadas de modo ou em local alternativo e a manutenção de backup dos dados em instalações próprias ou, no limite, a não transferência de dados críticos para nuvens;

- Outro aspecto importante a ser considerado é a possibilidade do provedor interromper a prestação dos serviços de forma definitiva ou deixar de dispor de condições para continuar prestando os serviços da maneira pactuada; para prevenir-se de situações desta natureza, é recomendável a elaboração de um plano de contingência, para viabilizar a continuidade dos serviços de modo alternativo.

- Privacidade:

- A integridade das informações é uma questão mandatória, seja em ambientes de computação em nuvem ou com recursos próprios;

- Os provedores devem adotar instrumentos e procedimentos os mais avançados disponíveis e esforçar-se para prover níveis de segurança e privacidade melhores dos que os alcançáveis com o emprego recursos computacionais próprios. 
- Suporte:

- Atualmente, o que se percebe é que o suporte aos consumidores não é prestado nos níveis adequados;

- Os provedores necessitam prover um suporte de melhor qualidade que aquele oferecido internamente.

- Aprisionamento e interoperabilidade:

- O aprisionamento e a baixa interoperabilidade são problemas para os consumidores, que, entretanto, já convivem com situações deste tipo ao adquirirem outros serviços que não os de computação em nuvem.

- Conformidade:

- As empresas necessitam atender a dispositivos legais de diversas naturezas, o que as obriga a preservar documentos e manter certas regras de conduta;

- Em decorrência, torna-se necessário que os provedores de serviços em nuvem agreguem às suas ofertas instrumentos que garantam aos seus consumidores o atendimento a esses dispositivos legais.

Smith (op. cit.) também oferece uma lista de riscos a serem considerados:

- Privacidade:

- Muitas empresas hesitam em transferir seus dados para um computador externo que potencialmente possa permitir que esses dados sejam acessados por outras empresas que venham a compartilhar esse computador;

- Todavia, não há registro de ocorrências de acesso a dados de um cliente por parte de algum outro operando numa mesma nuvem; esta situação de aparente adequada proteção pode derivar tanto do fato de efetivamente haver segurança suficiente nos ambientes de nuvem quanto de não ter havido, até aqui, interesse real neste tipo de invasão.

- Legislação:

- Os consumidores devem ficar atentos às leis particulares dos países nos quais os equipamentos dos provedores de serviços em nuvem estão instalados, pois elas se aplicam aos dados neles armazenados; 
- Por exemplo, empresas européias e asiáticas têm manifestado preocupação quanto a dados armazenados em computadores situados nos Estados Unidos, pois a legislação daquele país faculta ao governo o acesso a dados mantidos em seu território.

- Desempenho:

- Consumidores que utilizam serviços em nuvem há mais tempo têm reportado grandes variações no desempenho dos seus aplicativos;

- Situações deste tipo são decorrentes, em parte, do fato de que, quando se utiliza uma aplicação num ambiente de nuvem, não é possível saber ou prever quem serão os demais consumidores a compartilhar os recursos envolvidos e concorrer para uma eventual degradação do desempenho.

- Erros:

- Têm sido reportados, e deve ser um ponto de atenção, problemas ocorridos em decorrência de erros nem sempre adequadamente identificados, mas responsáveis por interrupções significativas nos serviços prestados por importantes provedores.

- Aprisionamento:

- A realidade atual mostra que os provedores têm oferecido serviços com características únicas e adotado mecanismos particulares para prover meios de comunicação para com os consumidores e outros provedores;

- A consequência é que os consumidores acabam por ficar limitados quanto à capacidade para transferir dados e aplicações para outros provedores.

- Capacidade finita:

- Aparentemente, um provedor de serviços em nuvem dispõe de recursos ilimitados para atender à demanda dos consumidores; entretanto, na realidade, evidentemente essa capacidade é finita e distribuída de algum modo eficiente entre os demandantes;

- Portanto, quando há situações em que a demanda se concentra em algum recurso com maior intensidade, pode não haver condições para que todos os demandantes sejam atendidos.

Armbrust et al. (op. cit.) também se envolvem com este tema, relacionando o que denominam os dez obstáculos para a adoção e o crescimento da utilização da computação em nuvem: 
- Disponibilidade dos serviços:

- Os consumidores preocupam-se se os serviços contratados terão disponibilidade satisfatória, pois este é um dos pontos críticos da computação em nuvem;

- O mecanismo de busca do Google é uma referência neste quesito - se as pessoas tentam fazer uma busca e este serviço não está disponível, acham que a Internet como um todo está "fora do ar";

- A alta disponibilidade de funções desta natureza faz com que os consumidores tenham a expectativa de que todo e qualquer serviço oferecido nas nuvens possa ter comportamento semelhante, o que nem sempre é verdadeiro.

- Aprisionamento dos dados:

- Apesar de existirem soluções técnicas para esta questão, a maioria dos provedores ainda não oferece a possibilidade de migração de dados de maneira fácil e ágil;

- Em decorrência, este é um tema que tem afugentado muitos consumidores, que não se sentem confortáveis com o fato de terem de conviver com limitações quanto à transferência de seus dados para outro provedor em caso de necessidade.

- Confidencialidade e auditoria dos dados:

- A legislação de vários países faculta a órgãos governamentais e reguladores o acesso a dados para fins de inspeções e auditorias;

- Como consequência, muitos consumidores incomodam-se com a perspectiva de que os provedores de serviços em nuvem sejam obrigados a liberar a esses órgãos o acesso a dados confidenciais.

- Gargalos de transferência de dados:

- Por questões diversas, pode ser conveniente para determinados consumidores transferir sistematicamente dados para e de seus provedores, com a finalidade de executar certos aplicativos específicos;

- Ocorre que, dependendo dos volumes a serem trafegados, esta transferência pode se tornar excessivamente demorada e custosa, recomendando uma cuidadosa análise e reavaliação dos aplicativos envolvidos.

- Imprevisibilidade do desempenho:

- A prática tem mostrado que múltiplas máquinas virtuais conseguem compartilhar de forma satisfatória memória e unidades centrais de processamento, mas que o 
compartilhamento de unidades de armazenamento é problemático, pois o desempenho é influenciado por aspectos mecânicos;

- Do mesmo modo, determinados processos que demandam alta dedicação das unidades centrais de processamento consomem muito mais tempo do que o esperado;

- Essas situações acabam por levar a um desempenho muito aquém do projetado para os recursos envolvidos.

- Escalabilidade da armazenagem:

- Apesar de este ser um dos argumentos de venda da computação em nuvem, os provedores têm enfrentado dificuldades técnicas para prover esta escalabilidade quando as estruturas de dados envolvidas se mostram complexas.

- Erros em sistemas distribuídos em alta escala:

- Tem se mostrado um desafio na computação em nuvem a eliminação de erros ocorridos neste tipo de sistema, pois é comum os desenvolvedores se depararem com o fato de não ser viável reproduzir os erros em ambientes de desenvolvimento para identificar suas causas, pois estes ambientes possuem configurações limitadas, totalmente distintas das existentes na operação efetiva.

- Escalação rápida:

- A rapidez para escalar recursos, tanto para mais quanto para menos, é importante, porém deve ocorrer de modo tal a permitir que essa variação no provisionamento de recursos seja feito sem prejuízo dos níveis de serviço pactuados e seja suportada por instrumentos justos de apropriação de custos para fins de cobrança.

- Má reputação:

- O comportamento inadequado de um único consumidor (como, por exemplo, a prática de spam ou o não atendimento a um dispositivo legal), ao se tornar de conhecimento do mercado, pode deixar transparecer ter havido a conivência do provedor;

- Situações deste tipo podem não apenas afetar a reputação do provedor, mas fazer com que os consumidores de uma maneira geral passem a ver a própria computação em nuvem com desconfiança.

- Licenciamento de software:

- Os esquemas de cobrança praticados pelos desenvolvedores de software para licenciar seus produtos não têm se mostrado compatíveis com a maneira pela qual estão sendo 
compostas as ofertas de serviços em nuvens, o que, por vezes, leva a situações que inviabilizam o uso de determinados software em função do custo para os consumidores.

Qian et al. (op. cit.) também exploram a questão dos riscos na computação em nuvem, destacando:

- Privacidade e segurança:

- O consumidor preocupa-se com sua privacidade e com a segurança de seus dados mais do que o faz num serviço tradicional de hospedagem;

- Continuidade dos serviços:

- Diz respeito a questões tais como erros, falta de energia e outras interrupções de ordem diversa, que podem interferir na continuidade da prestação dos serviços, afetando, inclusive, os níveis de serviço pactuados;

- Aprisionamento:

- Até o momento, não há uma padronização das interfaces externas dos diversos provedores de serviços em nuvem, o que significa que, uma vez um consumidor vinculando-se a um determinado provedor, ela praticamente fica preso a esse provedor, sem possibilidade de migrar seus serviços para outro.

Jensen et al. (op. cit.) analisam a questão dos riscos na computação em nuvem, porém sob uma ótica mais tecnicista e suas principais considerações estão sumarizadas no Quadro 7.

Quadro 7 - Riscos de Origem Técnica Presentes na Computação em Nuvem

\begin{tabular}{ll}
\hline Risco & Detalhe \\
\hline \hline $\begin{array}{l}\text { Adulteração da } \\
\text { Assinatura XML }\end{array}$ & $\begin{array}{l}\text { Modificação fraudulenta da assinatura XML em mensagem trocada entre web services, } \\
\text { possibilitando a substituição da mensagem original por outra, potencialmente danosa. }\end{array}$ \\
\hline $\begin{array}{l}\text { Falhas de } \\
\text { segurança dos } \\
\text { browsers }\end{array}$ & $\begin{array}{l}\text { Mesmo considerando a implementação de criptografia, os browsers disponíveis no } \\
\text { mercado não possuem mecanismos completos de segurança, que impeçam totalmente a } \\
\text { interceptação de mensagens. }\end{array}$ \\
\hline $\begin{array}{l}\text { Falhas de } \\
\text { integridade da } \\
\text { nuvem }\end{array}$ & $\begin{array}{l}\text { Propicia a introdução fraudulenta de web services com funções destinadas a provocar o } \\
\text { mauncionamento de serviços operados na nuvem. }\end{array}$ \\
\hline $\begin{array}{l}\text { Ataques por } \\
\text { saturação }\end{array}$ & $\begin{array}{l}\text { Pode levar a uma redução drástica de desempenho, em decorrência de sobrecarga dos } \\
\text { servidores ao tentar interpretar solicitações sem sentido, submetidas com o único } \\
\text { propósito de desestabilizar o ambiente. }\end{array}$ \\
\hline
\end{tabular}

FONTE: Adaptado de JENSEN et al.; 2009; p. 111-115. 


\subsubsection{Considerações Sobre a Questão do Risco na Computação em Nuvem}

Quanto aos riscos inerentes à computação em nuvem, a questão se configura de modo distinto do demandado pelos tópicos explorados no Capítulo 1 deste documento. Aqui, não se trata de selecionar uma proposição para ser adotada, mas de consolidar as listas apresentadas no tópico anterior, com vistas a preparar uma base que possibilite a verificação da pertinência dessas listas, tendo em vista o escopo dos objetivos estabelecidos para esta pesquisa.

A revisão bibliográfica realizada levou à seleção das cinco listas de riscos expostas no tópico acima. Cada um dos riscos citados nestas listas foi analisado em detalhe, à luz das definições oferecidas pelos autores, e os itens considerados idênticos ou muito assemelhados foram unificados; do mesmo modo, itens de significado muito próximo foram integrados, passando a compor um único. Por fim, foi instituído um critério de agrupamento, procurando estabelecer um primeiro nível de estruturação para os itens constantes da lista consolidada. O resultado obtido está apresentado no Quadro 8 e serviu de referência para a posterior validação empírica proposta pela pesquisa.

Quadro 8 - Consolidação dos Riscos Inerentes à Computação em Nuvem

\begin{tabular}{|c|c|c|c|}
\hline Grupo & Risco & Definição & Fontes \\
\hline \multirow[t]{6}{*}{ Operacionais } & $\begin{array}{l}\text { Falta de } \\
\text { privacidade }\end{array}$ & $\begin{array}{l}\text { Baixo grau de confidencialidade e } \\
\text { deficiências de isolamento no ambiente da } \\
\text { nuvem, possibilitando acessos indevidos e/ou } \\
\text { adulteração de dados e/ou aplicativos de } \\
\text { consumidores }\end{array}$ & $\begin{array}{l}\text { Kim; Smith; Armbrust } \\
\text { et al.; Qian et al. }\end{array}$ \\
\hline & $\begin{array}{l}\text { Falhas de } \\
\text { integridade }\end{array}$ & $\begin{array}{l}\text { Permissividade para a introdução fraudulenta } \\
\text { de agentes de software com funções } \\
\text { destinadas a provocar o mau funcionamento } \\
\text { de serviços operados na nuvem }\end{array}$ & Jensen et al. \\
\hline & Erros & $\begin{array}{l}\text { Falhas que implicam na necessidade de } \\
\text { reprocessar rotinas e/ou recuperar dados }\end{array}$ & Smith; Armbrust et al. \\
\hline & $\begin{array}{l}\text { Suporte } \\
\text { inadequado }\end{array}$ & $\begin{array}{l}\text { Falhas de natureza diversa no serviço de } \\
\text { suporte: pessoal mal preparado, gargalos no } \\
\text { atendimento, indisponibilidade do serviço } \\
\text { etc. }\end{array}$ & Kim \\
\hline & $\begin{array}{l}\text { Baixo } \\
\text { desempenho }\end{array}$ & $\begin{array}{l}\text { Desempenho insatisfatório dos serviços } \\
\text { contratados, em decorrência de picos de } \\
\text { demanda, balanceamento inadequado e/ou } \\
\text { subdimensionamento dos recursos ou outros } \\
\text { fatores assemelhados }\end{array}$ & Smith; Armbrust et al. \\
\hline & $\begin{array}{l}\text { Ataques por } \\
\text { saturação }\end{array}$ & $\begin{array}{l}\text { Não detecção em tempo hábil de ataques que } \\
\text { geram sobrecarga dos servidores ao tentar } \\
\text { interpretar solicitações sem sentido que } \\
\text { desestabilizam o ambiente }\end{array}$ & Jensen et al. \\
\hline
\end{tabular}


Quadro 8 - Consolidação dos Riscos Inerentes à Computação em Nuvem (cont.)

\begin{tabular}{|c|c|c|}
\hline Grupo & Risco & Definição \\
\hline \multirow[t]{2}{*}{$\begin{array}{l}\text { Operacionais } \\
\text { (cont.) }\end{array}$} & $\begin{array}{l}\text { Dificuldade para } \\
\text { escalar }\end{array}$ & $\begin{array}{l}\text { Demora excessiva ou dificuldades para Armbrust et al. } \\
\text { provisionar ou liberar recursos da nuvem }\end{array}$ \\
\hline & $\begin{array}{l}\text { Baixa } \\
\text { interoperabilidade }\end{array}$ & $\begin{array}{l}\text { Dificuldade significativa ou, no limite, Kim; Armbrust et al. } \\
\text { impossibilidade de intercambiar dados e/ou } \\
\text { aplicativos entre distintos provedores }\end{array}$ \\
\hline \multirow[t]{2}{*}{ De Negócio } & Indisponibilidade & $\begin{array}{l}\text { Interrupção temporária dos serviços em Kim; Smith; Armbrust } \\
\text { decorrência de problemas técnicos ou de et al.; Qian et al. } \\
\text { ordem diversa de parte do provedor }\end{array}$ \\
\hline & Não-continuidade & $\begin{array}{l}\text { Interrupção definitiva da prestação dos Kim } \\
\text { serviços pelo provedor }\end{array}$ \\
\hline \multirow[t]{4}{*}{ Estruturais } & Não-conformidade & $\begin{array}{l}\text { Não atendimento a aspectos ditados pela Kim; Smith } \\
\text { legislação ou disciplinados por padrões de } \\
\text { larga aceitação na indústria }\end{array}$ \\
\hline & $\begin{array}{l}\text { Licenciamento } \\
\text { de software }\end{array}$ & $\begin{array}{l}\text { Limitações impostas ao provedor por Armbrust et al. } \\
\text { contratos de licenciamento de software } \\
\text { inadequadamente pactuados com seus } \\
\text { fornecedores }\end{array}$ \\
\hline & Aprisionamento & $\begin{array}{l}\text { Dificuldade significativa ou, no limite, Kim; Smith; Armbrust } \\
\text { impossibilidade de trocar de provedor, et al.; Qian } \text { et al. } \\
\text { devido a particularidades do ambiente }\end{array}$ \\
\hline & Má reputação & $\begin{array}{l}\text { Ampla repercussão de aspectos negativos Armbrust et al. } \\
\text { envolvendo a prestação de serviços a um } \\
\text { determinado consumidor ou a um grupo de } \\
\text { consumidores }\end{array}$ \\
\hline
\end{tabular}

O grupo dos riscos operacionais engloba os riscos passíveis de afetar o dia-a-dia da prestação dos serviços, ou por deficiências do próprio provedor, em termos de processos e/ou instrumentos de governança, ou por inadequação dos ativos e recursos por ele empregados (hardware, software, meios de comunicação e pessoal). O grupo dos riscos de negócio abrange aqueles associados à atitude do provedor, como empresa, frente a situações críticas que possam advir. $\mathrm{O}$ grupo dos riscos estruturais compreende os riscos passíveis de afetar a médio e longo prazos a prestação dos serviços, em decorrência de decisões deliberadamente tomadas pelo provedor em discordância com o senso comum e/ou o respeito à legislação.

\subsubsection{Gestão de Riscos na Computação em Nuvem}

À semelhança do que ocorre com qualquer outro aspecto dos negócios, constitui-se numa boa prática a adoção de uma abordagem baseada em avaliação dos riscos e da segurança, ao considerar a possibilidade de contratar serviços de computação em nuvem (CSA, op. cit.). 
A segurança é uma preocupação prioritária para muitos dos consumidores de computação em nuvem e tem uma parcela de influência nas decisões de compra. Este comportamento dos consumidores deve ser visto pelos provedores de serviços em nuvem como um importante direcionador para o aprimoramento das suas práticas de segurança (ENISA, 2009).

Uma postura voltada à segurança é caracterizada pela maturidade, eficácia e completude das regras de segurança implementadas, as quais devem focar desde as facilidades (segurança física), passando pela infra-estrutura de rede (segurança de rede), os sistemas (segurança de sistemas), a informação e os aplicativos (segurança de aplicativos) e envolvendo ainda as pessoas e os processos de trabalho (CSA, op. cit.).

As regras de segurança aplicáveis aos ambientes de computação em nuvem não são, na sua quase totalidade, diferentes das adotadas em qualquer outro ambiente de TI. Contudo, face às características das ofertas de serviço, dos modelos de implementação e das tecnologias empregados na computação em nuvem, podem advir riscos diferentes dos tradicionalmente associados à TI (Ibid.).

A CSA (op. cit.) estabeleceu um conjunto de domínios para a segurança em computação em nuvem, os quais estão agrupados em duas categorias: governança e operações. A categoria de governança compreende os domínios mais abrangentes, que endereçam questões estratégicas e de políticas no ambiente de computação em nuvem, ao passo que a categoria de operações foca em aspectos mais táticos da segurança. Em cada uma das categorias, são os seguintes os domínios definidos:

- Governança:

- Governança e gestão empresarial de riscos;

- Inovação legal e eletrônica;

- Conformidade e auditoria;

- Gestão do ciclo de vida da informação;

- Portabilidade e interoperabilidade.

- Operações:

- Segurança convencional, continuidade dos negócios e recuperação de desastres;

- Operações do data center; 
- Resposta a incidentes, notificações e reparos;

- Segurança de aplicativos;

- Criptografia e gerenciamento de chaves;

- Gerenciamento de identidades e acesso;

- Virtualização.

Na publicação Security Guidance for Critical Areas of Focus in Cloud Computing, da qual foram extraídas as categorias e os domínios acima apresentados, cada domínio é detalhado e a cada um deles está ainda associado um amplo elenco de recomendações (Ibid.).

Diferentemente do que já ocorre com a questão dos riscos inerentes à computação em nuvem, abordada no tópico 2.2.4, a literatura ainda não apresenta uma diversidade de proposições relativas à gestão dos riscos nestes ambientes. Na realidade, fica um tanto evidente que, no caso da gestão dos riscos, a abordagem está sendo conduzida mais no plano dos práticos do que dos acadêmicos e, portanto, as publicações tendem a ser mais oriundas de instituições do que de pesquisadores. Porém, mesmo no caso das instituições, foi possível identificar apenas um trabalho voltado a este tema, que é o desenvolvido pela CSA (op. cit.), mas cuja proposta é ainda parcial e consiste de um esquema destinado à aplicação por parte de potenciais consumidores de serviços em nuvem. Este esquema cobre unicamente a questão da decisão quanto à escolha de um provedor para processar um determinado conjunto de aplicações e compreende os seguintes passos:

- Passo 1 - Identificar os ativos a serem transferidos para a nuvem:

- Em linhas gerais, os ativos passíveis de serem tratados em nuvens enquadram-se em duas classes: (a) dados e (b) aplicativos, funções e processos; nos ambientes de nuvem, ou são movimentados dados ou então são realizados processamentos, envolvendo aplicativos, funções e processos;

- Os ativos de um consumidor de serviços de computação em nuvem não precisam estar em uma única localização física e nem mesmo alocados a um único provedor; além disso, todos os ativos não precisam estar em nuvens de terceiros, podendo parte deles permanecer em data centers convencionais do próprio consumidor;

- Neste contexto, o primeiro passo do processo de gestão dos riscos é determinar quais dados e/ou funções são passíveis de transferência para nuvens. 
- Passo 2 - Avaliar os ativos:

- Para os ativos que podem ser direcionados a nuvens, deve-se determinar sua importância para a organização; não é imperativo que esta avaliação seja extremamente detalhada, a menos que já exista um processo formal que possibilite realizá-la desta forma;

- Para cada ativo, devem ser formuladas as seguintes questões:

1. Qual seria o impacto se este ativo se tornasse de conhecimento público?

2. Qual seria o impacto se algum funcionário dos provedores tivesse acesso a este ativo?

3. Qual seria o impacto se este processo ou função fosse manipulado por um estranho?

4. Qual seria o impacto se este processo ou função deixasse de produzir os resultados esperados?

5. Qual seria o impacto se este dado fosse modificado de forma inesperada?

6. Qual seria o impacto se este ativo se tornasse indisponível por um período de tempo?

- Essencialmente, o objetivo das questões acima é avaliar os requisitos de confidencialidade, integridade e disponibilidade dos ativos e como estes atributos podem ser afetados se todos ou parte dos ativos sofrer algum tipo de manipulação ou acesso indevido na nuvem.

- Passo 3 - Confrontar os ativos com os modelos de implementação da computação em nuvem:

- De posse da avaliação, tem-se um entendimento da importância dos ativos envolvidos e pode-se então determinar quais modelos de implementação (vide Figura 3) são mais adequados e se os riscos inerentes a cada um deles são ou não aceitáveis;

- Com isto, chega-se a uma boa ideia acerca do grau de conforto da transição para a nuvem e quais modelos atendem aos requisitos de risco.

- Passo 4 - Avaliar os modelos e provedores potenciais:

- Neste passo, o foco recai sobre o grau de controle que será possível ter em cada oferta de serviços (software, plataforma e infra-estrutura) para implementar a gestão dos riscos junto aos provedores potenciais.

- Passo 5 - Esboçar os fluxos de dados possíveis:

- Para cada potencial provedor, deve-se mapear o fluxo de dados entre este, o consumidor e quaisquer outros possíveis intermediários; é importante conhecer os possíveis 
caminhos a serem percorridos pelos dados que serão transferidos para as nuvens, antes de se tomar a decisão final quanto à contratação.

A CSA (op. cit.) defende que, aplicando o processo acima exposto, os consumidores tornamse aptos a compreender: (a) a importância dos ativos que consideram passíveis de serem transferidos para nuvens de terceiros, (b) seu próprio grau de tolerância aos riscos associados a essa transferência e (c) quais possíveis combinações entre ofertas de serviços e modelos de implementação lhes são aceitáveis.

\subsubsection{Considerações Sobre as Proposições Relativas à Segurança e à Gestão de Riscos na Computação em Nuvem}

Recorrendo à Figura 6, que prima pela simplicidade, porém possui um significativo apelo visual, é imediato afirmar que, para posicionar-se numa situação de segurança ou no "plano da segurança" 11, uma organização necessita reduzir seus riscos até torná-los aceitáveis. Uma vez tornados aceitáveis, os riscos deixam de se constituir em perigo potencial e podem contribuir para o aproveitamento de oportunidades, como destacado pela ISO e pelo COSO.

Para possibilitar a uma organização posicionar-se no plano da segurança, o instrumento a ser empregado é a gestão dos riscos. Não faltam, na literatura, proposições voltadas à gestão de riscos e a pesquisa bibliográfica realizada conduziu à identificação de várias delas, dentre as quais este documento destaca: (a) no tópico 2.2.2, cinco roteiros genéricos para gestão de riscos em organizações, propostos por Kliem, Habegger, Raz e Hillson, Crouhy et al. e pela ISO; (b) no tópico 2.2.3, um roteiro para gestão de riscos da TI, introduzido por Westerman e Hunter e (c) no tópico 2.2.6, um roteiro parcial para gestão específica de riscos em ambientes de computação em nuvem, proposto pela CSA.

Em tese, é razoável supor que os modelos e esquemas válidos para a gestão dos riscos de uma maneira geral possam ser aplicados à gestão dos riscos da TI, assim como estes possam ser aplicados à gestão de riscos na computação em nuvem.

\footnotetext{
${ }^{11}$ Nota: semi-plano, na realidade, para ser geometricamente preciso, dado que a linha vertical tracejada da Figura 6 divide o plano em dois semi-planos: o da segurança, à esquerda, e o do perigo, à direita.
} 
De fato, quando se compara roteiros para gestão de risco, como os citados no tópico 2.2.2 deste documento, com aquele proposto por Westerman e Hunter (op. cit.) para a gestão dos riscos da TI, verifica-se que há total semelhança entre as atividades recomendadas por todos eles. Em particular, é imediato associar as etapas do esquema proposto por Habegger (op. cit.), descritas no tópico 2.2.2, com suas correspondentes exibidas na Figura 10, que oferece uma visão do esquema de Westerman e Hunter (op. cit.).

Da mesma forma, quando se analisa mais de perto o roteiro recomendado por Westerman e Hunter (op. cit.), pode-se entender que a etapa de identificação e avaliação de riscos nele presente pode ser adequadamente adaptada para contemplar os requisitos específicos inerentes à computação em nuvem. Se o esquema da CSA fosse completo, poderia ser adotado para compor um modelo de referência para a gestão de riscos na computação em nuvem; porém, como se trata de um esquema apenas parcial, torna-se necessário identificar ou elaborar um esquema completo de gestão de riscos para, aí sim, compor um modelo viável de ser aplicado. 


\section{MÉTODO DE PESQUISA}

Até este momento do estudo, os três primeiros objetivos secundários estabelecidos haviam sido alcançados e representados pelo conteúdo do Capítulo 2 deste documento. De modo a poder cumprir com o último objetivo secundário e com o objetivo principal, seria ainda necessário, respectivamente: (a) explorar e verificar a pertinência e adequação dos benefícios apontados e das proposições relativas às barreiras e aos riscos associados à computação em nuvem e (b) fazer recomendações destinadas a auxiliar os tomadores de serviços oferecidos em nuvens a tratar a questão dos riscos.

Para atender ao objetivo secundário remanescente, a opção metodológica foi pela realização de um painel Delphi, tomando por base as proposições relativas a barreiras e riscos e as indicações dos benefícios, conforme identificadas na literatura afeta à computação em nuvem e já devidamente condensadas, estruturadas e comentadas no Capítulo 2. Neste presente capítulo, o método Delphi é então apresentado em detalhe, passando-se pela sua definição, histórico, vantagens e desvantagens, modalidades e exemplos de aplicação e culminando com a justificativa para sua escolha como instrumento central desta pesquisa e com a definição da sistemática adotada para sua aplicação. Em face de uma série de fatores, adiante melhor explorados, o Delphi posicionou-se como o método mais indicado para possibilitar rever e refinar as considerações extraídas da literatura, contando com a colaboração e opinião de acadêmicos e profissionais de TI.

\subsection{O Método Delphi: Definição e Histórico}

O método Delphi foi desenvolvido pela Rand Corporation, nos Estados Unidos, na década de 50 do século passado, para apoiar pesquisas militares de cunho estratégico. De início denominado expert judgment (RAND CORPORATION, 2005), teve posteriormente sua denominação alterada para Delphi e foi, pela primeira vez, reportado num documento interno da Rand datado de 14/11/1951 e denominado "The use of experts for the estimation of bombing requirements" (DALKEY e HELMER, 1962). 
A divulgação do Delphi, entretanto, somente foi autorizada dez anos mais tarde, depois de transcorrido um prazo considerado satisfatório pela Rand e pelas autoridades militares norteamericanas, cabendo aos pesquisadores internos Dalkey e Helmer (op. cit.) realizá-la.

No instrumento utilizado para divulgação (ibid.), o Delphi é definido como um método que busca obter a opinião coletiva mais confiável de um grupo de especialistas, aos quais são aplicados questionários e/ou entrevistas individuais combinados com feedback controlado, ao longo de uma série de ciclos ou rodadas. Em assim procedendo, afirmam estes autores que o processo, se não leva obrigatoriamente ao consenso, no mínimo leva à convergência das respostas ao final de um número relativamente reduzido de ciclos.

Ao longo dos anos 50 e da primeira metade dos anos 60 do século passado, o método Delphi foi sendo aperfeiçoado pelos pesquisadores da Rand. Por meio de um novo estudo publicado, Dalkey (1967) explicita as características básicas do Delphi, na sua visão: (a) anonimato, (b) feedback controlado e (c) estatística associada à resposta coletiva. $\mathrm{O}$ anonimato implica no não conhecimento, por parte de cada um dos participantes, das opiniões individuais dos demais, com vistas a evitar quaisquer tipos de interferências ou influências. O feedback controlado continua significando a divulgação, ao término de cada ciclo, das opiniões dos participantes para os próprios, sob a forma de resumos padronizados elaborados pelos pesquisadores. A estatística associada à resposta coletiva é representada por um valor numérico, estatisticamente determinado, capaz de representar adequadamente o conjunto das opiniões dos especialistas ao final de cada ciclo.

Posteriormente, o próprio Dalkey (1969) associa à característica do feedback controlado a questão da iteração, reforçando a importância dos ciclos no processo de aplicação do Delphi e indicando sua vinculação inseparável ao feedback.

Após analisar diversos estudos nos quais o Delphi foi empregado, Linstone e Turoff (1975) propõem uma visão um pouco distinta e resumem sua definição e as características, afirmando que ele pode ser entendido como um método destinado a estruturar um processo de comunicação que permite a um grupo de indivíduos lidar com problemas complexos, por meio de: (a) feedback de contribuições individuais de informações e conhecimentos, (b) avaliação da opinião ou visão do grupo, (c) oportunidade para os participantes revisarem suas opiniões e (d) anonimato dos participantes. 
Mais tarde, outros autores, em particular Rowe et al. (1991), passam a considerar que são quatro as características básicas do Delphi, colocando a iteração em separado, e reforçam que a repetição do processo de questionamento por meio dos ciclos propicia aos especialistas a oportunidade de rever suas opiniões e respostas à luz do conhecimento agregado do grupo.

\subsection{Modalidades e Sistemáticas de Aplicação do Método Delphi}

Na sua formulação original, o método Delphi foi concebido para ser aplicado a situações que envolviam a necessidade de gerar estimativas relativas a um determinado tema ou assunto. Dalkey (1969) reforça que as aplicações iniciais do Delphi na Rand foram realizadas com este foco. Posteriormente, Delbecq et al. (1975) mencionam o emprego do Delphi na obtenção de pareceres sobre a importância relativa de quesitos afetos a um determinado tema, na modalidade que passou a ser conhecida como ranking form.

Schmidt (1997) destacou que, no caso da utilização do método Delphi voltada à obtenção de estimativas, seus próprios criadores, e outros autores posteriormente, definiram um esquema para aplicação, ao passo que a modalidade ranking form não dispunha até aquele momento de uma sistemática estruturada equivalente.

Para ser aplicado à obtenção de estimativas, Dalkey e Helmer (op. cit.) propõem como sistemática que em cada ciclo ou rodada: (a) sejam apresentadas questões aos especialistas participantes, (b) as respostas sejam colhidas, tabuladas, despersonalizadas e sumarizadas e (c) o sumário seja devolvido aos participantes, acompanhado por um novo questionamento.

Linstone e Turoff (op. cit.), por sua vez, apresentam uma sistemática para aplicação do método Delphi para a obtenção de estimativas composta por quatro etapas a serem executadas ao longo de cada ciclo:

- Etapa 1: explorar o objeto em discussão, ao longo da qual cada participante contribui com a informação individual de que dispõe relativamente ao tema;

- Etapa 2: obter a visão coletiva do grupo acerca do tema, com a explicitação dos pontos de concordância e discordância; 
- Etapa 3: se há pontos relevantes de discordância, reavaliar esses pontos, com vistas a explorar as diferenças e rever posições;

- Etapa 4: finalizar avaliação, ao longo da qual é concluída a análise da informação compilada e é produzido feedback para análise.

No que diz respeito à aplicação do Delphi na modalidade ranking form, Schmidt (op. cit.) propõe uma sistemática que consta de cinco etapas: identificar quesitos, determinar quesitos mais relevantes, ordenar quesitos, analisar resultados e apresentar resultados. Em detalhe, este esquema compreende:

- Etapa 1 - Identificar quesitos:

- Os painelistas devem ser encorajados a indicar o maior número possível de quesitos, de modo a garantir que os mais relevantes sejam, de fato, lembrados e indicados;

- Cada quesito deve, na medida do possível, ser acompanhado de uma descrição, que torne suficientemente claro o seu significado;

- Caso seja adotada a opção de recomendar aos painelistas uma quantidade mínima de quesitos a serem indicados, a quantidade ideal a ser sugerida é seis;

- Uma vez feitas as indicações por parte de todos os painelistas, o pesquisador deve interpretá-las e consolidá-las numa lista única, tendo o cuidado de garantir que quesitos que aparentem ser os mesmos, mas que possuam descrições diferentes, sejam adequadamente tratados.

- Etapa 2 - Determinar quesitos mais relevantes:

- Os quesitos constantes da lista consolidada elaborada na etapa anterior devem ser colocados numa sequência aleatória e assim enviados aos painelistas, aos quais será solicitado indicar uma certa quantidade mínima de quesitos como sendo os mais importantes ou relevantes;

- De posse das indicações, o pesquisador deve eliminar da lista única os quesitos não indicados pela maioria simples de painelistas (metade do tamanho do grupo mais um).

- Etapa 3 - Ordenar quesitos:

- Uma vez mais, os quesitos presentes na lista consolidada elaborada ao final da etapa anterior devem ser colocados numa sequência aleatória e assim enviados aos painelistas, aos quais será solicitado colocá-los em ordem de importância relativa; 
- De posse das listas ordenadas por cada um dos painelistas, o pesquisador deve consolidá-las, para finalmente obter um ranking representativo da opinião coletiva; esta consolidação deve ser realizada com o emprego de um método estatístico e existem vários deles aplicáveis a este caso, mas a recomendação, no entanto, é que seja utilizado o método de Kendall e Smith (1939), que conduz a uma solução única e de fácil obtenção e entendimento;

- Uma vez obtido o ranking coletivo, é importante verificar o grau de concordância existente entre os painelistas, o que pode ser medido pela estatística $\mathrm{W}$, denominada coeficiente de concordância (Ibid.); é igualmente relevante que a significância de W seja verificada, o que pode ser feito com o emprego de um teste de $\chi^{2}$;

- Quando se adota uma série de ciclos de consulta para refinar as opiniões dos painelistas relativamente ao ranking consolidado, esta mesma estatística $\mathrm{W}$ pode ser utilizada como instrumento para sinalizar quando a série de ciclos pode ser interrompida, pois o incremento no valor de $\mathrm{W}$ de um ciclo para outro tem relação direta com o aumento da concordância entre os painelistas; se não há um aumento significativo do valor de W de um ciclo para outro, o processo pode ser interrompido e a lista ordenada consolidada quando dessa interrupção é então utilizada como ranking definitivo.

- Etapa 4 - Analisar resultados:

- O ranking definitivo é analisado, buscando-se dele extrair conclusões relativas ao objeto da pesquisa.

- Etapa 5 - Apresentar resultados:

- Esta apresentação pode se dar sob diversas formas: texto, tabelas, quadros explicativos e gráficos;

- É importante que o pesquisador descreva todas as etapas do processo e relate as ocorrências mais relevantes, em particular as divergências havidas e os passos executados para sua resolução;

- Devem também fazer parte da documentação apresentada os cálculos realizados, os valores obtidos para as estatísticas adotadas e outros dados quantitativos relevantes.

Ainda relativamente à aplicação do Delphi na modalidade ranking form, Skulmoski et al. (2007) têm dado preferência à adoção de três ciclos e desenvolveram uma sistemática específica para tal, composta por 12 etapas e reproduzida na Figura 12. 
Figura 12 - Sistemática para Aplicação do Método Delphi em 3 Ciclos

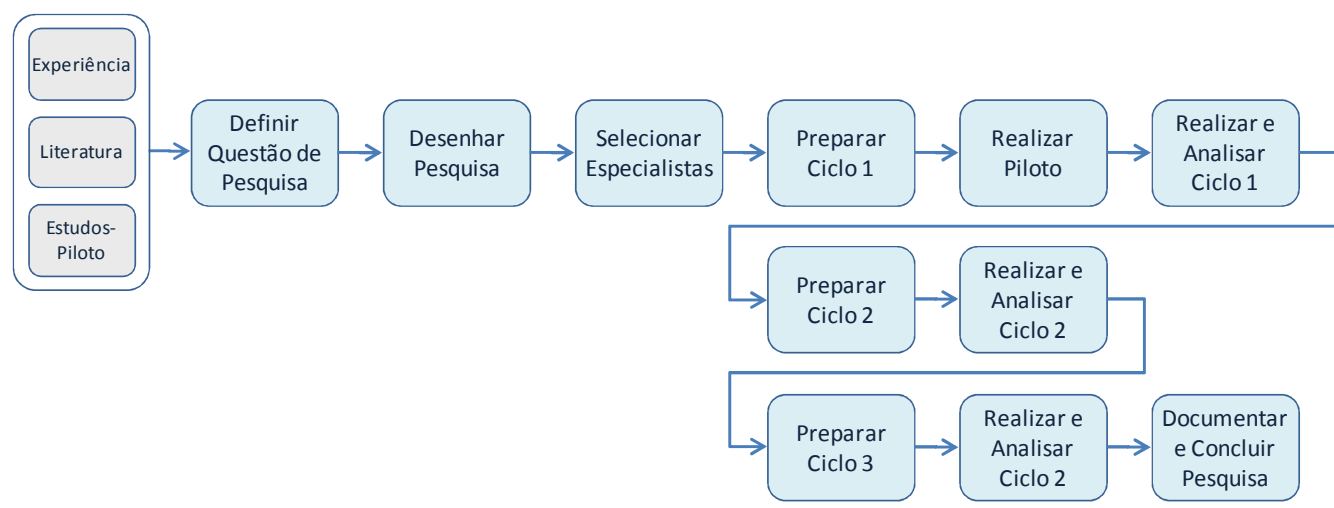

FONTE: Adaptado de SKULMOSKI et al.; 2007; p. 3.

Em detalhe, esta sistemática compreende:

- Etapa 0 - Organizar pesquisa:

- Considera a experiência do pesquisador relativamente ao tema escolhido para a pesquisa, complementada por uma revisão da literatura pertinente;

- Se necessário, estudos-piloto podem ser realizados, quando o pesquisador sente a necessidade de validar sua experiência sobre o tema e/ou certificar-se da relevância deste para os destinatários potenciais dos resultados da pesquisa.

- Etapa 1 - Definir questão de pesquisa:

- Abrange a explicitação da questão de pesquisa, que direciona todas as demais etapas do estudo.

- Etapa 2 - Desenhar pesquisa:

- Compreende a estruturação da pesquisa, com a escolha do método a ser empregado (neste caso particular, o Delphi) e o estabelecimento de todas as fases e atividades.

- Etapa 3 - Selecionar especialistas:

- Esta é uma etapa crítica do método Delphi;

- Em geral, há quatro requisitos que qualificam um especialista para participar da pesquisa: (a) conhecimento e experiência no tema em estudo, (b) aptidão e interesse, (c) disponibilidade e (d) habilidade em se comunicar.

- Etapa 4 - Preparar ciclo 1:

- Corresponde à elaboração do primeiro questionário a ser aplicado aos painelistas; 
- Requer cuidado e atenção da parte do pesquisador, de modo a produzir um elenco de questões que sejam efetivamente compreendidas e possam levar à obtenção de respostas adequadas para a evolução satisfatória do estudo.

- Etapa 5 - Realizar piloto:

- Esta não é uma etapa mandatória; pesquisadores experientes podem suprimi-la sem incorrer em prejuízos para a pesquisa;

- Se realizado, o piloto destina-se a validar o questionário inicial e o processo adotado para a condução do painel; pode-se, eventualmente, testar também os demais questionários a serem utilizados.

- Etapa 6 - Realizar e analisar ciclo 1:

- Congrega a distribuição do primeiro questionário, a recepção das respostas e a análise destas.

- Etapa 7 - Preparar ciclo 2:

- Corresponde à elaboração do segundo questionário da pesquisa, o qual deve basear-se nas respostas obtidas e conclusões da etapa anterior;

- O conteúdo deste questionário é também ditado pelos objetivos da pesquisa, dependendo de estes serem mais ou menos focados somente nas opiniões dos painelistas e de contemplarem estimativas ou rankings.

- Etapa 8 - Realizar e analisar ciclo 2:

- É análoga à etapa 6, com foco no segundo questionário.

- Etapa 9 - Preparar ciclo 3:

- É análoga à etapa 7;

- Este questionário já é bastante mais específico e direcionado, pois compreende as questões que finalizam as consultas aos especialistas.

- Etapa 10 - Realizar e analisar ciclo 3:

- É análoga às etapas 6 e 8, com foco no terceiro questionário;

- Adicionalmente, esta etapa deve conter um teste que verifique se o painel pode, de fato, ser dado por concluído ou se será necessária a realização de um ou mais novos ciclos; no caso de serem necessários ciclos adicionais, deve-se repetir as etapas 9 e 10 tantas vezes quantas forem necessárias. 
- Etapa 11 - Documentar e concluir pesquisa:

- Compreende a documentação dos resultados obtidos, de forma adequada para publicação;

- Deve contemplar ainda a exploração das possibilidades de generalização desses resultados e de extensão e complementação futuras da pesquisa.

Visando complementar o ferramental necessário à aplicação do método Delphi, Okoli e Pawlowski (2004) propõem uma sistemática para identificar e escolher os especialistas a serem convidados para participar de um painel Delphi. A Figura 13 apresenta uma visão sintética desta proposta.

Figura 13 - Sistemática para Escolha de Especialistas para um Painel Delphi

\begin{tabular}{|c|c|}
\hline $\begin{array}{l}\text { Passo 1: Preparar quadro de } \\
\text { requisitos }\end{array}$ & $\begin{array}{l}\text { - Identificar disciplinas e perfis relevantes } \\
\text { - Identificar organizações relevantes } \\
\text { - Identificar literatura acadêmica e não-acadêmica relevante }\end{array}$ \\
\hline \multicolumn{2}{|r|}{ - } \\
\hline $\begin{array}{l}\text { Passo 2: Popular quadro de } \\
\text { requisitos com candidatos }\end{array}$ & $\begin{array}{l}\text { - Associar pessoas às disciplinas e perfis relevantes } \\
\text { - Listar pessoas vinculadas às organizações relevantes } \\
\text { - Listar pessoas vinculadas à literatura relevante }\end{array}$ \\
\hline \multicolumn{2}{|r|}{ 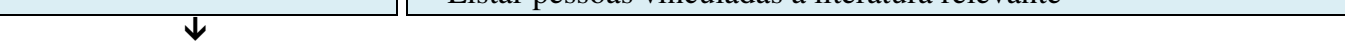 } \\
\hline $\begin{array}{l}\text { Passo 3: Identificar } \\
\text { especialistas adicionais }\end{array}$ & $\begin{array}{l}\text { - Contatar os especialistas candidatos } \\
\text { - Solicitar aos especialistas a indicação de pessoas adicionais que } \\
\text { satisfaçam aos requisitos }\end{array}$ \\
\hline \multicolumn{2}{|r|}{3} \\
\hline $\begin{array}{l}\text { Passo 4: Elaborar ranking } \\
\text { dos especialistas }\end{array}$ & $\begin{array}{l}\text { - Criar uma sublista para cada painel independente a ser conduzido } \\
\text { - Alocar os especialistas aos painéis (e às sublistas) } \\
\text { - Classificar os especialistas com base em suas qualificações }\end{array}$ \\
\hline \multicolumn{2}{|r|}{ 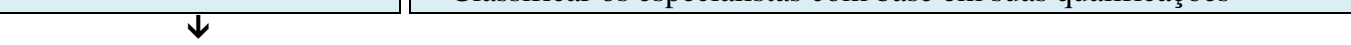 } \\
\hline $\begin{array}{l}\text { Passo 5: Convidar } \\
\text { especialistas }\end{array}$ & $\begin{array}{l}\text { - Convidar os especialistas, de acordo com o ranking } \\
\text { - Objetivar contar com entre } 10 \text { e } 18 \text { especialistas, parando o processo } \\
\text { quando este objetivo for alcançado }\end{array}$ \\
\hline
\end{tabular}

FONTE: Adaptado de OKOLI e PAWLOWSKI; 2004; p. 21.

Rowe e Wright (2001), por sua vez, sugerem um conjunto de princípios práticos para nortear a aplicação do Delphi, os quais estão relacionados no Quadro 9.

Quadro 9 - Princípios Práticos para Aplicação do Método Delphi

\begin{aligned} & \hline Princípio Enunciado \\ & \hline \hline 1 Convoque especialistas com conhecimento adequado \\ & \hline 2 Utilize especialistas com perfil heterogêneo \\ & \hline 3 Empregue entre cinco e 20 especialistas \\ & \hline\end{aligned}


Quadro 9 - Princípios Práticos para Aplicação do Método Delphi (cont.)

\begin{aligned} & \hline Princípio Enunciado \\ & \hline \hline 4 $\begin{array}{l}\text { Para o feedback, disponibilize a média ou a mediana das opiniões, acrescidas das razões } \\ \text { apresentadas pelos especialistas para suas indicações }\end{array} \\ &$\hline 5 $\begin{array}{l}\text { Continue com os ciclos até que as respostas mostrem estabilidade; em geral, três ciclos são } \\ \text { suficientes }\end{array} \\ &$\hline 6 $\begin{array}{l}\text { Obtenha o resultado final agregando as opiniões de todos os especialistas e atribuindo pesos } \\ \text { iguais a elas }\end{array} \\ &$\hline 7 Ao elaborar as questões, empregue definições claras e sucintas e evite termos emotivos \\ & \hline 8 Estruture as questões de forma balanceada \\ & \hline 10 $\begin{array}{l}\text { Evite incorporar informação irrelevante às questões } \\ \text { ou expressões não usuais }\end{array} \\ &$\hline 11 Realize testes de coerência ao estimar probabilidades \\ & \hline\end{aligned}

FONTE: Adaptado de ROWE e WRIGHT; 2001; p. 127-135.

\subsection{Exemplos de Aplicação do Método Delphi}

Gupta e Clarke (1996) realizaram um extenso levantamento bibliográfico sobre a utilização do método Delphi no período compreendido entre 1975 e 1994 e identificaram 463 artigos nos quais o Delphi foi empregado, sendo que em 254 deles como técnica principal e nos restantes 209 como técnica secundária, com as aplicações distribuindo-se entre as mais diversas áreas de conhecimento: educação, negócios, gestão, marketing, manufatura, finanças, economia, recursos humanos, saúde, informação e gestão, mercado imobiliário, negócios internacionais, ciências sociais, engenharia, lazer e turismo, meio ambiente e transportes.

Schmidt (op. cit.), por sua vez, menciona a existência de aplicações do método Delphi, na modalidade de estimativa, nos campos da administração pública, medicina e difusão de tecnologia e, na modalidade ranking form, nos campos da educação, gestão de operações e TI. Rowe e Wright (1999) citam estudos em saúde, marketing, educação, TI, transporte e engenharia nos quais foi empregado o Delphi. Okoli e Pawlowski (op. cit.) apresentam uma extensa relação de estudos em TI nos quais foi aplicado o método Delphi, tanto para produzir estimativas quanto para elaborar rankings. De modo semelhante, Skulmoski et al. (op. cit.) também apresentam uma lista de estudos, em TI e em outras áreas de conhecimento que não a TI, nos quais o Delphi foi empregado. 
Todo esse conjunto de exemplos mostra a versatilidade e a amplitude de utilização do método Delphi. Reproduzindo palavras de Skulmoski et al. (op. cit., p. 2): "O Delphi é um método de pesquisa maduro e bastante adaptável, utilizado por pesquisadores em muitos distintos campos de pesquisa ao redor do mundo." 12

No levantamento que realizaram, Rowe e Wright (1999) selecionaram, para analisar em mais detalhe, 27 estudos publicados entre 1962 e 1996 nos quais o Delphi foi aplicado e verificaram que em cerca de dois terços deles foram realizados apenas dois ou três ciclos (respectivamente, em oito e em nove estudos), sendo que, nos demais, foram executados de quatro a sete ciclos. Nestes estudos, a quantidade de especialistas envolvidos variou de três a 98, com maior concentração na faixa de quatro a 11.

Já no seu levantamento, Skulmoski et al. (op. cit.) documentaram a aplicação do Delphi a 16 diferentes estudos publicados entre 1973 e 2005 e detectaram que em 11 deles foram realizados três ciclos, em outros três apenas dois ciclos e, nos dois remanescentes, um único ciclo. Considerando todo o conjunto de estudos, a quantidade de especialistas envolvidos variou de três a 171, com maior concentração na faixa de nove a 21.

Estes últimos autores (ibid.) também promoveram um extenso levantamento acerca da utilização do Delphi em teses e dissertações. Identificaram, à época, cerca de 280 trabalhos desta natureza na base ProQuest (www.proquest.co.uk/en-UK/default.shtml) e examinaram 41 deles em maior detalhe; entre estes, predominaram uma vez mais as aplicações com três ciclos, em número de 29, contra sete com dois ciclos, quatro com quatro ciclos e um com cinco ciclos. A quantidade de especialistas envolvidos variou de oito a 345 , com maior concentração na faixa de 11 a 37. Os temas das dissertações e teses também foram os mais variados, abrangendo TI, educação, saúde, medicina, psicoterapia, administração e esportes.

Como parte do levantamento preliminar integrante desta pesquisa, foi feita, em 20/08/2010, uma consulta ao banco eletrônico de teses da Universidade de São Paulo (www.teses.usp.br), utilizando a busca avançada deste sítio com o argumento "Delphi" no resumo ou nas palavras-

\footnotetext{
12 "The Delphi method is a mature and a very adaptable research method used in many research arenas by researchers across the globe."
} 
chave. Esta pesquisa resultou na identificação de nove dissertações de mestrado e 14 teses de doutorado, de autoria de estudantes brasileiros, nas quais o método Delphi foi empregado. Dentre estes trabalhos, a área de enfermagem está contemplada com sete estudos, as áreas de engenharia civil e saúde com três estudos cada, as áreas de recursos humanos e tecnologia nuclear com dois cada e os demais se distribuem entre TI, administração, contabilidade, engenharia de produção, educação e esporte. O Apêndice 1 apresenta detalhes acerca destas dissertações e teses, relacionadas em ordem cronológica.

\subsection{Justificativa para a Escolha do Método Delphi}

Um exercício de exploração e verificação da pertinência e adequação de proposições por meio da opinião de especialistas pode ser feito com o emprego de diversos métodos distintos de análise científica, entre os quais se inclui o Delphi.

Hallowell e Gambatese (2010) comentam alguns métodos alternativos ao Delphi:

\section{- Staticized Group:}

- Este método é semelhante ao Delphi, mas limita-se à realização de um ciclo ou rodada, não buscando o refinamento das opiniões dos especialistas nem tampouco o consenso, o qual, se ocorre, dá-se por acaso e não em decorrência de uma busca sistematizada;

- A questão do anonimato é preservada.

\section{- Focus Group:}

- Também é semelhante ao Delphi, porém possibilita a interação entre os participantes, dado que os trabalhos são realizados em sessões ou reuniões das quais todos os painelistas participam;

- Em decorrência, o anonimato não é preservado e abre-se espaço para a ocorrência das situações consideradas mais negativas nas interações presenciais: (a) a dominação e (b) a dificuldade das pessoas em se expor, reconhecendo opiniões próprias equivocadas e procurar modificá-las ou corrigi-las;

- Há ainda a questão logística, que pode ser impactante, pois todos os participantes devem ser reunidos num único local físico, a menos que se viabilizem esquemas de comunicação visual e oral à distância (do tipo videoconferências ou assemelhados). 


\section{- Nominal Group Technique, NGT:}

- Combina o Delphi com o Focus Group, na medida em que as opiniões são colhidas isoladamente (tal como no Delphi), porém o feedback é fornecido reunindo-se o grupo de participantes (como no Focus Group);

- Acaba por incorporar as desvantagens dos dois métodos.

Graefe e Armstrong (2011) acrescentam à lista acima o prediction markets, que é um método cuja aplicação se dá por meio da negociação de contratos entre os participantes, num contexto que preserva o anonimato; este artigo apresenta um estudo comparativo entre o Focus Group, NGT, prediction markets e Delphi, focando na precisão e aceitação do método pelos participantes, e conclui que o Delphi é o mais preciso. Já Rowe e Wright (1999) incluíram em seu estudo uma revisão bibliográfica sobre a aplicação de métodos de obtenção de opiniões de especialistas e concluíram que, à época, o Delphi era, de longe, o mais utilizado.

Estes estudos apenas reforçam as colocações feitas por estes outros autores, porém sem uma comprovação prática:

- Linstone e Turoff (op. cit.) destacam que há preferência pelo Delphi quando:

- Os especialistas que podem ser envolvidos não apresentam um histórico de comunicação adequada entre si;

- Possa ser necessário envolver uma quantidade de especialistas grande a ponto de inviabilizar a comunicação presencial;

- O tempo e o custo esperados representam restrições que podem inviabilizar a realização de reuniões presenciais com a frequência necessária;

- Há a expectativa de que a eficiência do contato presencial possa ser melhorada com o suporte de um processo estruturado de comunicação;

- O histórico de relacionamento entre os especialistas indica haver divergências de tal ordem que justifiquem o anonimato e a introdução de um processo de comunicação arbitrado por terceiros;

- A heterogeneidade entre os participantes deva ser preservada, para assegurar a validade dos resultados, no caso, por exemplo, de poder haver prevalência de opiniões por força da personalidade de um ou mais indivíduos e/ou vantagem numérica decorrente do tamanho de um subgrupo. 
- Isaac e Michael (1995) defendem que o Delphi:

- Evita que ocorra o chamado efeito "Maria vai com as outras", comum nas interações presenciais, quando um líder nato ou de ocasião conduz os demais;

- Torna o processo menos vulnerável à influência que pode ser exercida por um indivíduo ou subgrupo dominante, em função de prestígio ou imposição pela força;

- Reduz a inibição dos especialistas em se expor, em função de mudanças de opinião.

- Rowe e Wright (2001) são mais enfáticos ao defender a superioridade do Delphi e, em adição, relacionam quatro condições que recomendam seu emprego:

- Quando o julgamento por parte de especialistas é necessário, porque o emprego de métodos estatísticos não é apropriado;

- Quando há especialistas disponíveis;

- Quando a opção que se apresenta como alternativa é considerar uma média de opiniões ou estimativas de vários indivíduos isoladamente;

- Quando a opção que se apresenta como alternativa limita-se à realização de um trabalho convencional em grupo.

Evidentemente, o Delphi não é apropriado em todo e qualquer estudo de obtenção de opiniões de especialistas. Veltri (1985), citado por Hallowell e Gambatese (op. cit.), destaca este ponto, afirmando que o Delphi não é a melhor escolha quando: (a) não há especialistas disponíveis na quantidade necessária; (b) há especialistas disponíveis, porém estes não se dispõem ou não têm possibilidade de participar; (c) o objetivo da pesquisa não é obter consenso entre os especialistas e (d) não há, entre os pesquisadores, ao menos um indivíduo dotado de características tais que lhe permitam exercer de modo satisfatório o papel de facilitador.

No caso específico do presente estudo, dado o caráter inovador do tema e as características exploratórias da pesquisa, buscava-se empregar um método que possibilitasse rever e refinar as proposições relativas a barreiras, benefícios e riscos identificadas na pesquisa bibliográfica, contando com a colaboração e opinião de profissionais de TI, de modo a incorporar um senso prático às considerações de cunho mais acadêmico nelas contidas. Em adição, entendia-se como importante minimizar a ocorrência de efeitos indesejados nas interações, tais como, a dominação, a limitação das pessoas em se expor para rever e aprimorar opiniões e a dificuldade de relacionamento entre os participantes (que poderia já existir a priori ou se 
desenvolver durante o trabalho). Também se considerava fundamental utilizar um método que levasse gradativamente à obtenção da opinião coletiva do grupo (se possível, chegando a um consenso) e respeitasse o período de tempo e o orçamento relativamente limitados disponíveis para a realização do trabalho, sem introduzir restrições logísticas que pudessem agravar o processo.

Nesse contexto, a escolha preliminar do Delphi pareceu ser a mais adequada. De todo modo, avaliou-se ainda a realidade da situação à luz das condições estabelecidas por Rowe e Wright (2001), acima citadas, e verificou-se que todas elas estavam presentes. Este fato somente reforçou a escolha, fazendo com que, a partir desse momento, o Delphi passasse a ser considerado a opção definitiva.

\subsection{O Método Delphi Aplicado a Este Estudo}

Dadas as características desta pesquisa, a modalidade ranking form de aplicação do método Delphi foi considerada a mais adequada. Nesta modalidade, poder-se-ia explorar as questões das barreiras, benefícios e riscos associados à computação em nuvem e estabelecer listas ordenadas dos elementos mais relevantes de cada grupo, segundo a opinião dos especialistas participantes do painel.

O painel Delphi foi então conduzido nesta modalidade e, para tal, foi definida a adoção de uma sistemática derivada dos esquemas desenvolvidos por Schmidt (op. cit.), por Skulmoski et al. (op. cit.) e por Okoli e Pawlowski (op. cit.). Recordando resumidamente o que já foi citado no tópico 3.3 deste documento:

- Schmidt (op. cit.) propõe uma sistemática para a aplicação do Delphi na modalidade ranking form que consiste de cinco etapas: exploração dos quesitos, determinação dos quesitos mais relevantes, ordenação dos quesitos, análise dos resultados e apresentação dos resultados;

- Skulmoski et al. (op. cit.) propõem uma sistemática mais detalhada (vide Figura 12), composta por 12 etapas e especificamente desenhada para a realização de um painel Delphi de três ciclos; desconsiderando as etapas que se apresentam de maneira repetida de um ciclo para outro, esta sistemática contém, na realidade, apenas oito etapas distintas; 
- Okoli e Pawlowski (op. cit.) propõem um esquema específico e bastante detalhado para a seleção de especialistas para participar de um painel Delphi.

Combinando então essas três proposições, definiu-se a sistemática adotada no painel realizado para suportar este trabalho de pesquisa, a qual compreende cinco etapas, apresentadas no Quadro 10 de forma comparativa para com relação aos esquemas utilizados como referência.

Quadro 10 - Comparação Entre Sistemáticas de Aplicação do Método Delphi

\begin{tabular}{|c|c|c|c|}
\hline $\begin{array}{l}\text { Sistemática Adotada } \\
\text { Neste Estudo }\end{array}$ & $\begin{array}{l}\text { Sistemática Proposta } \\
\text { por Skulmoski et al. }\end{array}$ & $\begin{array}{l}\text { Sistemática Proposta } \\
\text { por Okoli e Pawlowski }\end{array}$ & $\begin{array}{c}\text { Sistemática Proposta } \\
\text { por Schmidt }\end{array}$ \\
\hline $\begin{array}{l}\text { 1. Esquematizar } \\
\text { Painel }\end{array}$ & - Desenhar Pesquisa & & \\
\hline $\begin{array}{l}\text { 2. Montar Grupo de } \\
\text { Painelistas }\end{array}$ & - Selecionar Especialistas & $\begin{array}{l}\text { - Preparar Quadro de } \\
\text { Requisitos } \\
\text { - Popular Quadro de } \\
\text { Requisitos com Candidatos } \\
\text { - Identificar Especialistas } \\
\text { Adicionais } \\
\text { - Elaborar Ranking dos } \\
\text { Especialistas } \\
\text { - Convidar Especialistas }\end{array}$ & \\
\hline $\begin{array}{l}\text { 3. Preparar Ciclo N } \\
\text { do Painel }\end{array}$ & $\begin{array}{l}\text { - Preparar Ciclo } \mathrm{N}^{\mathbf{1}} \\
\text { - Realizar Piloto }\end{array}$ & & $\begin{array}{l}\text { - Explorar Quesitos } \\
\text { - Determinar Quesitos }\end{array}$ \\
\hline $\begin{array}{l}\text { 4. Realizar Ciclo N } \\
\text { do Painel }\end{array}$ & $\begin{aligned}- & \text { Realizar e Analisar } \\
& \text { Ciclo } \mathrm{N}^{\mathbf{1}}\end{aligned}$ & & $\begin{array}{l}\text { Mais Relevantes } \\
\text { - Ordenar Quesitos }\end{array}$ \\
\hline $\begin{array}{l}\text { 5. Elaborar } \\
\text { Conclusões }\end{array}$ & $\begin{array}{l}\text { - Documentar e Concluir } \\
\text { Pesquisa }\end{array}$ & & $\begin{array}{l}\text { - Analisar Resultados } \\
\text { - Apresentar Resultados }\end{array}$ \\
\hline
\end{tabular}

\footnotetext{
1 A referência a um ciclo genérico $\mathrm{N}$ é uma adaptação à proposição original destes autores, que definem etapas distintas
} para cada um dos ciclos (vide Figura 12).

Em detalhe, as etapas da sistemática adotada no presente estudo compreendem:

- Etapa 1 - Esquematizar Painel:

- Engloba a esquematização geral do painel, com a pré-definição da quantidade de ciclos e dos temas a serem explorados em cada ciclo e ainda com o esboço de cada um dos questionários a serem aplicados;

- Esta etapa não encontra uma correspondente plena em nenhum dos esquemas utilizados como referência, mas é imprescindível de ser executada neste nível de detalhe, pois estabelece a estrutura a ser adotada no painel. 
- Etapa 2 - Montar Grupo de Painelistas:

- A montagem do grupo compreende a identificação dos participantes em potencial, a seleção daqueles a serem convidados, o convite propriamente dito e as rodadas de negociação para a participação, estas últimas envolvendo agendas, disponibilidades, impedimentos e demais aspectos logísticos;

- A identificação e seleção dos participantes em potencial devem levar em conta uma série de fatores de qualificação ou requisitos, entre os quais a vivência no tema da pesquisa, a bagagem acadêmica (quando aplicável) e o interesse em participar;

- Esta etapa segue um roteiro derivado do esquema proposto por Okoli e Pawlowski (op. cit.), com as devidas adaptações que estes próprios autores recomendam para cada painel em particular;

- Adicionalmente, é ainda nesta etapa que é definido o número de participantes do painel, para o que não há uma regra única universalmente aceita; as referências bibliográficas citadas e os exemplos apresentados nos tópicos 3.2 e 3.3 deste documento conduzem ao demonstrativo apresentado no Quadro 11, no qual se observa a ampla variação na quantidade de painelistas utilizados:

\section{Quadro 11 - Dimensionamento de Painéis Delphi}

\begin{tabular}{|c|c|c|c|c|c|}
\hline Autor & Natureza & $\begin{array}{l}\text { Mínimo } \\
\text { ou Único }\end{array}$ & Máximo & \multicolumn{2}{|c|}{$\begin{array}{l}\text { Intervalo de } \\
\text { Concentração }\end{array}$} \\
\hline Ana Beatriz Poli Veronezi & Dissertação & 39 & - & - & - \\
\hline Ariane Fazzolo Scarparo & Dissertação & 54 & - & - & - \\
\hline Celso Huerta Gimenes & Dissertação & 99 & - & - & - \\
\hline Cesar Hidetoshi Enoki & Dissertação & 21 & - & - & - \\
\hline Janaína Anchieta Costa & Dissertação & 11 & - & - & - \\
\hline Luana Torelli da Silva & Dissertação & 21 & - & - & - \\
\hline Manuela Modesto Dantas & Dissertação & 21 & - & - & - \\
\hline Marcia Galan Perroca & Dissertação & 15 & - & - & - \\
\hline Milton Satocy Nakano & Dissertação & 72 & - & - & - \\
\hline Alberto de Medeiros Jr. & Tese & 27 & - & - & - \\
\hline Angelo Just da Costa e Silva & Tese & 34 & - & - & - \\
\hline Carlos Roberto dos Santos & Tese & 10 & - & - & - \\
\hline Cleuza Catsue Takeda Kuwabara & Tese & 134 & - & - & - \\
\hline Eline Lima Borges & Tese & 65 & - & - & - \\
\hline Emanoel Marcos Lima & Tese & 14 & - & - & - \\
\hline
\end{tabular}


Quadro 11 - Dimensionamento de Painéis Delphi (cont.)

\begin{tabular}{|c|c|c|c|c|c|}
\hline Autor & Natureza & $\begin{array}{l}\text { Mínimo } \\
\text { ou Único }\end{array}$ & Máximo & \multicolumn{2}{|c|}{$\begin{array}{l}\text { Intervalo de } \\
\text { Concentração }\end{array}$} \\
\hline Jacqueline Veneroso Alves da Cunha & Tese & 15 & - & - & - \\
\hline Liliane Parreira Tannús Gontijo & Tese & 20 & - & - & - \\
\hline Marcos Augusto Rocha & Tese & 13 & - & - & - \\
\hline Maria Alice Morato Ribeiro & Tese & 122 & - & - & - \\
\hline Maria Luiza de Moraes Leonel Padilha & Tese & 45 & - & - & - \\
\hline Regina Rigatto Witt & Tese & 52 & - & - & - \\
\hline Ricardo Luis Wust Corrêa de Lyra & Tese & 19 & - & - & - \\
\hline Simone Silva da Cunha Vieira & Tese & 12 & - & - & - \\
\hline Okoli e Pawlowski (op. cit.) & Recomendação & 10 & 18 & - & - \\
\hline Rowe e Wright (2001) & Recomendação & 5 & 20 & - & - \\
\hline Rowe e Wright (1999) & Artigos & 3 & 98 & 4 & 11 \\
\hline Skulmoski et al. (op. cit.) & Artigos & 3 & 171 & 9 & 21 \\
\hline Skulmoski et al. (op. cit.) & Teses & 8 & 345 & 11 & 37 \\
\hline
\end{tabular}

- Tomando por base os números constantes do Quadro 11 e analisando cada um dos exemplos citados, observa-se que, considerado um intervalo de concentração entre quatro e 37 (que é o intervalo mais amplo, dados os limites mínimo e máximo verificados para o conjunto de intervalos indicados nas últimas três linhas do quadro), a maioria dos painéis utilizou uma quantidade de participantes que se enquadra entre estes limites.

- Etapa 3 - Preparar Ciclo N do Painel:

- Corresponde ao preparo do questionário relativo a cada um dos ciclos do painel;

- Skulmoski et al. (op. cit.) destacam que o questionário a ser utilizado no primeiro ciclo pode ser composto por questões ou abertas ou estruturadas; as questões abertas são aquelas que solicitam aos painelistas expor sua opinião sem lhes oferecer nenhum tipo de referência explícita, enquanto que as questões estruturadas já oferecem um ponto de partida aos painelistas, que são solicitados a trabalhar a partir deste;

- Por exemplo, uma questão aberta é do tipo: "cite, na sua opinião, os principais benefícios que podem ser obtidos com a aquisição de serviços de computação em nuvem", ao passo que uma questão estruturada relativa ao mesmo tema poderia ser: "a literatura menciona que a redução dos investimentos iniciais, a escalabilidade dinâmica e a menor 
mobilização de recursos de pessoal e infra-estrutura são alguns dos principais benefícios que podem ser obtidos com a aquisição de serviços de computação em nuvem; você discorda de algum item desta lista e/ou acrescentaria algum outro benefício a ela?";

- As questões abertas tendem a ampliar o escopo da discussão, pois permitem aos painelistas elaborar as respostas sem se prender a um referencial direcionador, ao passo que as questões estruturadas, quanto mais referências oferecem, tendem a limitar o escopo da discussão, condicionando os painelistas a seguir a linha de raciocínio proposta pelo pesquisador;

- Os questionários a serem utilizados nos demais ciclos do painel, além do primeiro ciclo, possuem, caracteristicamente, questões fechadas, pois estas focam no tratamento de quesitos já introduzidos em algum ciclo anterior.

- Etapa 4 - Realizar Ciclo N do Painel:

- Corresponde ao encaminhamento do questionário relativo a cada um dos ciclos aos painelistas, ao acompanhamento e cobrança das respostas e à posterior tabulação e análise dessas respostas; como se trata de um painel do tipo ranking, as respostas dos painelistas são voltadas, essencialmente, à proposição e ordenação de listas e as indicações individuais são consolidadas, de modo a se obter opiniões coletivas, cujo grau de concordância, no caso das ordenações, é verificado;

- De posse das respostas às questões que envolvem proposição, a consolidação visa obter os elementos distintos coletivamente propostos, representativos, portanto, da opinião do grupo de painelistas sobre um dado tema; para tal, desprezam-se as eventuais indicações de elementos repetidos (os que possuem definições semelhantes) e tomam-se todas as indicações distintas assim identificadas para compor listas de proposições;

- No que se refere às respostas às questões que envolvem ordenação, para obter os elementos coletivamente mais indicados, representativos, ainda uma vez, da opinião do grupo de painelistas sobre um dado tema, aplica-se o método de ordenação coletiva escolhido, que, neste caso, é o método proposto por Kendall e Smith (op. cit.), com a variante destinada a equacionar a questão dos empates recomendada por Kendall (1945);

- Em linhas gerais, este método de ordenação coletiva propõe que, de início, a cada elemento presente numa lista ordenada individual, se atribua um peso correspondente à sua posição na lista, ou seja, para o elemento colocado na posição 1 , o peso deve ser 1 , para o elemento colocado na posição 2 , o peso deve ser 2 e assim por diante; estes pesos 
devem ser atribuídos às listas de cada ordenador e a soma dos pesos de um elemento passa a representar sua posição na lista coletiva, de tal modo que o elemento com menor soma ocupa a posição 1 , o elemento com a segunda menor soma ocupa a posição 2 e assim sucessivamente;

- Nos ciclos em que as listas não são efetivamente ordenadas pelos painelistas, mas apenas são indicados os $\mathrm{Z}$ elementos mais relevantes, a cada um destes o método recomendaria ser atribuído o peso 1 e, aos demais não selecionados, o peso $\mathrm{Z}+1$, caracterizando empates tanto entre os selecionados quanto entre os não selecionados; nesta situação, Kendall (op. cit.) propõe que os pesos dos elementos empatados sejam substituídos pela média aritmética das posições por eles ocupadas;

- Depois de obtida a ordenação coletiva, o grau de concordância entre os painelistas é verificado, por meio do cálculo da estatística W (denominada coeficiente de concordância), conforme proposto por Kendall (op. cit.); a interpretação do grau de concordância é feita empregando as faixas sugeridas por Schmidt (op. cit.):

\begin{tabular}{ll}
\hline Faixas para o Grau de Concordância & Significado \\
\hline \hline Até 0,1 & Muito baixo \\
\hline Acima de 0,1 e até 0,3 & Baixo \\
\hline Acima de 0,3 e até 0,5 & Moderado \\
\hline Acima de 0,5 e até 0,7 & Alto \\
\hline Acima de 0,7 e até 0,9 & Muito alto \\
\hline
\end{tabular}

- A significância de W é também verificada, aplicando-se um teste de $\chi^{2}$, seguindo a orientação de Friedman (1940).

- Etapa 5 - Elaborar Conclusões:

- Compreende o preparo das conclusões finais, baseadas nos resultados obtidos com a realização de todos os ciclos do painel;

- Neste estudo, as conclusões finais versam sobre a visão dos painelistas relativamente aos riscos, benefícios e barreiras potenciais associados aos ambientes de computação em nuvem não privada. 


\section{REALIZAÇÃO DO PAINEL DELPHI}

Para complementar o cumprimento do quarto e último objetivo secundário desta pesquisa, qual seja, o de explorar e verificar a pertinência e adequação dos benefícios apontados e das proposições relativas às barreiras e aos riscos associados à computação em nuvem, e uma vez tendo sido selecionado o método de pesquisa para tal e definida uma sistemática para sua aplicação, na sequência, realizou-se efetivamente a aplicação.

Neste capítulo é, então, detalhado o processo de realização do painel Delphi, que foi conduzido entre fevereiro e junho de 2011, seguindo a sistemática definida no tópico 3.5.

\subsection{Esquematização do Painel}

Depois de analisar diversas opções para composição dos questionários e estruturação dos ciclos do painel, chegou-se à definição de, no mínimo, seis ciclos, com os escopos apresentados na Figura 14.

Figura 14 - Ciclos de Aplicação do Método Delphi Neste Estudo

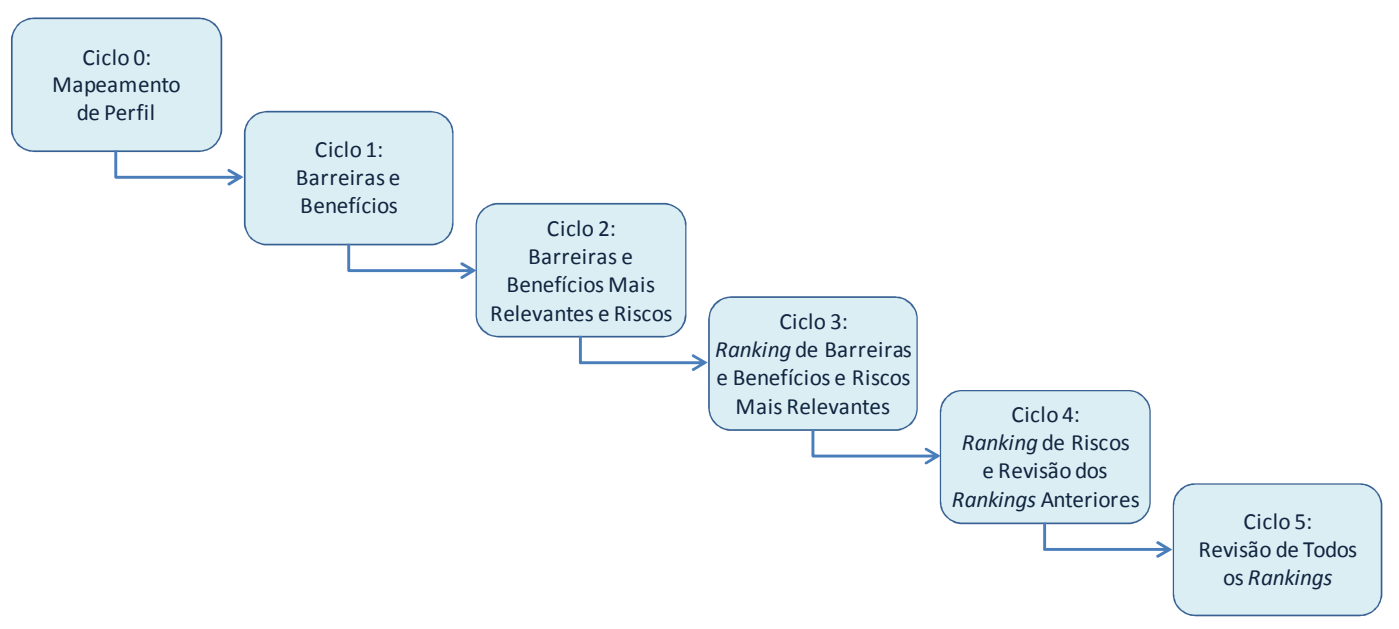

O Ciclo 0 seria um ciclo preliminar, destinado a mapear o perfil dos profissionais de TI participantes do painel. O Ciclo 1 seria efetivamente o primeiro voltado à exploração do tema da pesquisa e à captura das indicações de barreiras e benefícios da computação em nuvem. $\mathrm{O}$ 
Ciclo 2 aprofundaria a investigação, iniciando a composição dos rankings de barreiras e benefícios e colhendo indicações relativas aos riscos inerentes à computação em nuvem. $\mathrm{O}$ Ciclo 3 complementaria a definição dos rankings de barreiras e benefícios e iniciaria a composição do ranking de riscos. O Ciclo 4 complementaria a definição do ranking de riscos e promoveria a revisão dos rankings de barreiras e benefícios, visando aprimorar o grau de concordância entre os participantes. O Ciclo 5, também com foco no aprimoramento do grau de concordância, revisaria o ranking de riscos e promoveria, se necessário, uma nova revisão dos rankings de barreiras e benefícios, podendo encerrar a aplicação do painel Delphi.

Se, após a realização do Ciclo 5, algum grau de concordância ainda se mantivesse dentro de uma faixa muito baixa, dentre as recomendadas por Schmidt (op. cit.), seriam acrescentados ao painel novos ciclos semelhantes a este, até se obter graus de concordância satisfatórios ou concluir pela impossibilidade de melhorar a concordância entre os painelistas relativamente aos temas em questão.

\subsection{Montagem do Grupo de Painelistas}

Optou-se pela realização de um painel com a participação de um grupo único de especialistas, porém reunindo acadêmicos e profissionais de TI. Esta composição tem a vantagem de poder dotar o grupo de uma visão ampla sobre o tema, mesclando experiência e conhecimentos práticos com um toque de enfoque acadêmico. Okoli e Pawlowski (op. cit.) deixam antever esta possibilidade, citando alguns estudos em que o grupo de especialistas foi constituído desta forma: Czinkota e Ronkainen (1997), Viehland e Hughes (2002), Holsapple e Joshi (2002).

Com esta composição mista, uma maior participação de gestores de TI pareceu ser mais conveniente, pois eles é que representariam os interessados diretos nas recomendações finais do trabalho; isto posto, uma proporção que se afigurou satisfatória foi algo da ordem de quatro a cinco gestores de TI para cada acadêmico.

Para selecionar os especialistas candidatos a participar do painel, foi estabelecido um elenco de fatores de qualificação, a saber: 
- Conhecimento avançado sobre computação em nuvem;

- Reconhecida competência no respectivo mercado de trabalho;

- Interesse efetivo em participar de um estudo desta natureza;

- Disponibilidade concreta de tempo para participar dos trabalhos na intensidade prevista, ou seja, cinco ciclos com dedicação estimada de uma hora para responder a cada questionário;

- Para os profissionais de TI, o exercício de um cargo executivo de alto nível nas empresas em que atuavam.

Tomadas estas decisões, deu-se início à elaboração de uma lista de potenciais participantes, reunindo nomes de pessoas do círculo de conhecimento do pesquisador. Esta lista acabou composta por 22 pessoas, as quais foram contatadas por e-mail ou telefone e receberam um convite para participar do painel.

Paralelamente, foram identificados profissionais do meio acadêmico com envolvimento direto e efetivo com a TI, dentre os quais foram escolhidos três professores-doutores, aos quais também foi feito o convite.

O convite foi aceito pelos três acadêmicos e por 13 profissionais de TI, estabelecendo-se então um grupo de 16 painelistas, com tamanho e proporção relativa (um acadêmico para cada 4,3 profissionais de TI) considerados ambos satisfatórios.

\subsection{Realização do Ciclo 0 do Painel}

Este ciclo abrangeu o preparo e envio de um questionário destinado ao mapeamento do perfil dos profissionais de TI participantes do painel e a subsequente tabulação das respostas recebidas.

O questionário deste ciclo foi composto por dez perguntas, com a última delas objetivando colher eventuais comentários gerais dos painelistas e as nove iniciais destinadas ao mapeamento do perfil, investigando desde os títulos dos cargos ocupados até as publicações costumeiramente lidas, passando ainda pela qualificação da natureza e porte das empresas nas 
quais os painelistas atuavam. $O$ texto na íntegra das perguntas que compuseram este questionário está apresentado no Apêndice 2.

Este questionário foi enviado apenas aos 13 profissionais de TI, tendo sido respondido por todos eles. O perfil dos acadêmicos foi obtido por meio de contato direto por e-mail. Um resumo das respostas obtidas, tanto aos questionários quanto aos e-mails, está apresentado no Apêndice 3.

\subsection{Realização do Ciclo 1 do Painel}

Este ciclo abrangeu o preparo e envio do primeiro questionário destinado a abordar efetivamente o tema da pesquisa e a posterior tabulação das respostas recebidas. Nesta pesquisa, optou-se por compor este questionário apenas com questões abertas, de modo a captar ao máximo a vivência e a experiência pregressas dos painelistas sobre o tema.

Este questionário compreendeu oito perguntas, sendo a última delas, da mesma forma que no anterior, destinada ao registro de eventuais comentários. As sete questões iniciais objetivaram colher a opinião dos painelistas acerca das barreiras que podem inibir a contratação de serviços de computação em nuvem não privada e dos benefícios que podem ser obtidos com esta modalidade de contratação. $O$ texto na íntegra das perguntas que compuseram este questionário está também apresentado no Apêndice 2.

Este questionário foi enviado aos 16 painelistas, tendo sido respondido pelos três acadêmicos e por apenas 11 dentre os 13 profissionais de TI.

No que diz respeito às barreiras potenciais, a compilação e interpretação das indicações feitas pelos painelistas levou à obtenção de uma lista com 16 barreiras distintas, cuja relação está apresentada no Quadro 12.

Já no que tange aos benefícios potenciais, a compilação e interpretação das indicações feitas pelos painelistas levou à obtenção de uma lista com 12 benefícios distintos, os quais estão relacionados no Quadro 13. 


\section{Quadro 12 - Barreiras Potenciais à Adoção da Computação em Nuvem Não Privada Indicadas pelos Painelistas}

No. Enunciado

B1 Maturidade ainda não comprovada do modelo de serviços e governança, por ser muito novo

B2 Riscos inerentes ao modelo de serviços, muitos dos quais ainda desconhecidos e que podem não ser adequadamente esclarecidos pelo fornecedor

B3 Oferta de serviços ainda limitada

B4 Custo elevado dos serviços ofertados

B5 Dúvidas quanto à segurança que possa vir a ser oferecida pelo fornecedor

B6 Dúvidas quanto à capacidade do fornecedor em garantir disponibilidade e dispor de recursos para atender a contingências

B7 Dúvidas quanto à qualidade dos recursos de infra-estrutura e rede de comunicações adotados pelo fornecedor

B8 Dúvidas quanto à capacidade do fornecedor em realizar em tempo hábil a implantação e expansão dos serviços contratados

B9 Dúvidas quanto à capacidade do fornecedor em atender a urgências

B10 Dúvidas quanto à capacidade e agilidade do fornecedor em prover suporte

B11 Dúvidas quanto à capacidade do fornecedor em negociar satisfatoriamente e atender a SLA's

B12 Dúvidas quanto ao tratamento a ser recebido de parte do fornecedor, face à eventual baixa representatividade dos serviços contratados

B13 Receio quanto à comunicação com um fornecedor estrangeiro, por conta de dificuldades com o idioma

B14 Falta de cultura por parte do comprador

B15 Investimentos recentes realizados pelo comprador em infra-estrutura própria

B16 Dúvidas quanto à viabilidade da terceirização de determinados serviços, em função de criticidade dos negócios e necessidade de controle

\section{Quadro 13 - Benefícios Potenciais Decorrentes da Adoção da Computação em Nuvem Não Privada Indicados pelos Painelistas}

\begin{tabular}{ll}
\hline No. & Enunciado \\
\hline \hline V1 & Permite concentrar o foco de TI nos negócios e em processos core \\
\hline V2 & Propicia maior simplicidade e menor esforço para gerir os ativos alocados a TI \\
\hline V3 & $\begin{array}{l}\text { Reduz ou elimina a necessidade de lidar com planejamento de capacidade e outros processos } \\
\text { associados a ativos próprios }\end{array}$ \\
\hline V4 & Gera oportunidade para aprimoramento tecnológico e absorção de novos conhecimentos \\
\hline V5 & Demanda investimentos iniciais menores para se dispor do mesmo nível de recursos e tecnologia \\
\hline V6 & Viabiliza a implantação mais rápida de novos serviços e aplicativos \\
\hline V7 & Confere maior grau de disponibilidade aos serviços \\
\hline V8 & $\begin{array}{l}\text { Oferece escalabilidade, proporcionando flexibilidade para crescer e lidar com situações de pico e } \\
\text { sazonalidade }\end{array}$ \\
\hline V9 & Propicia portabilidade aos serviços, viabilizando trocas de fornecedores \\
\hline
\end{tabular}


Quadro 13 - Benefícios Potenciais Decorrentes da Adoção da Computação em Nuvem Não Privada Indicados pelos Painelistas (cont.)

No. Enunciado

V10 Possibilita redução global de investimentos e de gastos com custeio de TI

V11 Permite substituir investimentos em ativos (CAPEX) por despesas (OPEX), gerando benefícios fiscais

V12 Aumenta o nível global de segurança em TI, desde que cumpridos os SLA's pelos fornecedores

\subsection{Realização do Ciclo 2 do Painel}

Este ciclo abrangeu o preparo e envio do segundo questionário efetivamente relacionado ao tema da pesquisa e a posterior tabulação e análise das respostas obtidas.

Este questionário foi composto por cinco perguntas, sendo a última delas, uma vez mais, destinada a colher comentários dos painelistas. As duas primeiras questões direcionaram os painelistas a indicar as dez barreiras e os dez benefícios mais relevantes, dentre os presentes na consolidação das respostas dadas às questões do ciclo anterior. As duas questões remanescentes destinaram-se a colher a opinião dos painelistas acerca dos riscos inerentes à contratação de serviços de computação em nuvem não privada. O texto na íntegra das perguntas que compuseram este questionário está igualmente apresentado no Apêndice 2.

Este questionário foi enviado aos 14 painelistas remanescentes, tendo sido excluídos aqueles que não enviaram suas respostas na rodada anterior. Foram recebidas respostas dos três acadêmicos e de nove profissionais de TI.

\subsubsection{Preparo da Questão Relativa às Barreiras}

No caso das barreiras à adoção da computação em nuvem, foi feito um confronto, antes da elaboração da lista a ser inserida neste questionário, entre as 16 barreiras relacionadas no Quadro 12 e as nove consolidadas no Quadro 5, estas últimas extraídas de estudos acadêmicos. Este confronto levou à conclusão de que as barreiras indicadas pelos painelistas constituíam-se num conjunto mais amplo, englobando na íntegra o conteúdo obtido das referências bibliográficas (feitas as adequadas interpretações das definições) e acrescentando considerações não abordadas na literatura consultada, caso específico das seguintes barreiras: 
- B3 - Oferta de serviços ainda limitada;

- B4 - Custo elevado dos serviços ofertados;

- B9 - Dúvidas quanto à capacidade do fornecedor em atender a urgências;

- B10 - Dúvidas quanto à capacidade e agilidade do fornecedor em prover suporte;

- B12 - Dúvidas quanto ao tratamento a ser recebido de parte do fornecedor, face à eventual baixa representatividade dos serviços contratados;

- B13 - Receio quanto à comunicação com um fornecedor estrangeiro, por conta de dificuldades com o idioma;

- B15 - Investimentos recentes realizados pelo comprador em infra-estrutura própria;

- B16 - Dúvidas quanto à viabilidade da terceirização de determinados serviços, em função de criticidade dos negócios e necessidade de controle.

\subsubsection{Preparo da Questão Relativa aos Benefícios}

No caso dos benefícios, antes da elaboração da lista a ser inserida neste questionário, foi igualmente feito um confronto, desta vez entre os 12 benefícios relacionados no Quadro 13 e os nove consolidados no Quadro 4, estes últimos apontados em estudos acadêmicos. Este confronto permitiu concluir que os benefícios citados pelos painelistas coincidiam com parte dos extraídos das referências bibliográficas (feitas as adequadas interpretações das definições) e identificar dois benefícios relevantes não indicados pelos painelistas, quais sejam: o acesso a inovações e a menor mobilização de recursos destinados a TI. Estes dois benefícios foram então numerados, respectivamente, como V13 e V14 e acrescentados à lista dos indicados, de modo a compor a questão específica sobre este tema neste questionário.

\subsubsection{Respostas Relativas às Barreiras e Benefícios}

Apesar de solicitados a indicar dez barreiras e dez benefícios, nem todos os painelistas o fizeram, tendo sido indicados apenas nove, oito e até mesmo sete elementos em alguns casos.

De todo modo, de posse das respostas, foram elaboradas duas listas consolidadas, uma com as barreiras e outra com os benefícios, cada uma delas com os dez elementos mais indicados de cada tipo, representativos, portanto, da opinião coletiva do grupo de painelistas. Para obter os 
elementos coletivamente mais indicados em cada lista, foi aplicado o método de ordenação escolhido, já mencionado no tópico 3.5, isto é, o método proposto por Kendall e Smith (op. cit.), com a variante destinada a equacionar a questão dos empates recomendada por Kendall (op. cit.).

Dado que, neste ciclo, as listas não estão ordenadas pelos painelistas, mas apenas estão indicados os dez elementos mais relevantes, a cada um deles o método recomenda ser atribuído o peso 1 e, aos demais não selecionados, o peso 11, caracterizando empates tanto entre os selecionados quanto entre os não selecionados. Para eliminar os empates, a variante do método propõe substituir os pesos iguais pela média aritmética das posições por eles ocupadas. Neste caso, como os empates entre os dez elementos indicados se dão nas posições de 1 a 10, os pesos destes elementos são substituídos por 5,5, valor que corresponde à média da soma dos valores de 1 a 10; para os elementos não indicados dentre as barreiras (cujas posições vão de 11 a 16), o peso médio é 13,5 e, dentre os benefícios (cujas posições vão de 11 a 14), o peso médio é 12,5. Para as listas individuais cujas indicações contemplam menos que dez elementos, os pesos atribuídos aos itens empatados são diferentes destes, pois as médias são outras.

Os pesos atribuídos aos elementos de todas as listas individuais elaboradas pelos painelistas estão apresentados na Tabela 1 para as barreiras e na Tabela 2 para os benefícios. Em adição, essas tabelas contêm os resultados dos cálculos efetuados para a obtenção das listas ordenadas coletivas; as fórmulas de cálculo envolvidas, bem como o significado das variáveis constantes das Tabelas 1 e 2, estão apresentados no Apêndice 4.

Tabela 1 - Barreiras Mais Relevantes (Opinião dos Painelistas)

\begin{tabular}{|c|c|c|c|c|c|c|c|c|c|c|c|c|c|c|c|c|c|c|c|}
\hline \multirow{2}{*}{ Painelistas } & \multicolumn{16}{|c|}{ Barreiras } & \multicolumn{3}{|c|}{ Efeito dos Empates } \\
\hline & B1 & B2 & B3 & B4 & B5 & B6 & B7 & B8 & B9 & B10 & B11 & B12 & B13 & B14 & B15 & B16 & t1 & t2 & $T$ \\
\hline A & 4,5 & 4,5 & 12,5 & 12,5 & 4,5 & 4,5 & 12,5 & 12,5 & 4,5 & 12,5 & 4,5 & 12,5 & 12,5 & 4,5 & 12,5 & 4,5 & 8 & 8 & 84 \\
\hline$B$ & 5,5 & 5,5 & 5,5 & 5,5 & 5,5 & 5,5 & 5,5 & 13,5 & 5,5 & 13,5 & 5,5 & 13,5 & 13,5 & 13,5 & 5,5 & 13,5 & 10 & 6 & 100 \\
\hline C & 5 & 5 & 5 & 13 & 5 & 5 & 13 & 13 & 13 & 13 & 13 & 13 & 5 & 5 & 5 & 5 & 9 & 7 & 88 \\
\hline D & 4,5 & 4,5 & 12,5 & 12,5 & 4,5 & 12,5 & 12,5 & 12,5 & 4,5 & 4,5 & 4,5 & 12,5 & 12,5 & 4,5 & 4,5 & 12,5 & 8 & 8 & 84 \\
\hline E & 5,5 & 5,5 & 13,5 & 13,5 & 5,5 & 5,5 & 5,5 & 13,5 & 5,5 & 5,5 & 5,5 & 13,5 & 13,5 & 13,5 & 5,5 & 5,5 & 10 & 6 & 100 \\
\hline $\mathrm{F}$ & 5,5 & 5,5 & 5,5 & 13,5 & 5,5 & 5,5 & 13,5 & 13,5 & 5,5 & 5,5 & 5,5 & 13,5 & 13,5 & 13,5 & 5,5 & 5,5 & 10 & 6 & 100 \\
\hline G & 5,5 & 13,5 & 5,5 & 5,5 & 5,5 & 5,5 & 13,5 & 5,5 & 5,5 & 5,5 & 5,5 & 13,5 & 5,5 & 13,5 & 13,5 & 13,5 & 10 & 6 & 100 \\
\hline $\mathrm{H}$ & 5,5 & 5,5 & 5,5 & 13,5 & 5,5 & 5,5 & 13,5 & 13,5 & 5,5 & 5,5 & 5,5 & 13,5 & 13,5 & 13,5 & 5,5 & 5,5 & 10 & 6 & 100 \\
\hline I & 5,5 & 5,5 & 5,5 & 13,5 & 5,5 & 5,5 & 5,5 & 13,5 & 5,5 & 5,5 & 5,5 & 13,5 & 13,5 & 13,5 & 13,5 & 5,5 & 10 & 6 & 100 \\
\hline J & 12 & 12 & 4 & 12 & 4 & 12 & 12 & 12 & 4 & 4 & 4 & 4 & 12 & 12 & 12 & 4 & 7 & 9 & 88 \\
\hline$K$ & 13 & 5 & 5 & 13 & 5 & 5 & 5 & 13 & 13 & 13 & 13 & 5 & 13 & 5 & 5 & 5 & 9 & 7 & 88 \\
\hline $\mathrm{L}$ & 12,5 & 12,5 & 12,5 & 12,5 & 4,5 & 4,5 & 4,5 & 4,5 & 4,5 & 4,5 & 4,5 & 4,5 & 12,5 & 12,5 & 12,5 & 12,5 & 8 & 8 & 84 \\
\hline $\mathrm{R}=\sum$ ranks & 84,5 & 84,5 & 92,5 & 140,5 & 60,5 & 76,5 & 116,5 & 140,5 & 76,5 & 92,5 & 76,5 & 132,5 & 140,5 & 124,5 & 100,5 & 92,5 & & $\sum T=$ & 1116 \\
\hline$X=R-\bar{x}$ & $-17,5$ & $-17,5$ & $-9,5$ & 38,5 & $-41,5$ & $-25,5$ & 14,5 & 38,5 & $-25,5$ & $-9,5$ & $-25,5$ & 30,5 & 38,5 & 22,5 & $-1,5$ & $-9,5$ & & & \\
\hline$Y=X^{\wedge} 2$ & 306,25 & 306,25 & 90,25 & 1482,3 & 1722,3 & 650,25 & 210,25 & 1482,3 & 650,25 & 90,25 & 650,25 & 930,25 & 1482,3 & 506,25 & 2,25 & 90,25 & & & \\
\hline & & & & & & $\begin{array}{r}\mathrm{n}= \\
\mathrm{m}=\end{array}$ & $\begin{array}{l}16 \\
12\end{array}$ & $\begin{array}{l}\overline{\mathbf{x}}= \\
\mathbf{S}=\end{array}$ & $\begin{array}{r}102,0 \\
10652,0\end{array}$ & $\begin{array}{l}W= \\
x^{2}=\end{array}$ & \begin{tabular}{r|}
0,299 \\
53,907
\end{tabular} & & & & & & & & \\
\hline
\end{tabular}


Tabela 2 - Benefícios Mais Relevantes (Opinião dos Painelistas)

\begin{tabular}{|c|c|c|c|c|c|c|c|c|c|c|c|c|c|c|c|c|c|}
\hline \multirow{2}{*}{ Painelistas } & \multicolumn{14}{|c|}{ Benefícios } & \multicolumn{3}{|c|}{ Efeito dos Empates } \\
\hline & V1 & V2 & V3 & V4 & V5 & V6 & V7 & V8 & V9 & V10 & V11 & V12 & V13 & V14 & $\mathrm{t1}$ & t2 & \begin{tabular}{c|c|}
$T$ \\
\end{tabular} \\
\hline A & 11,5 & 4,5 & 4,5 & 11,5 & 4,5 & 4,5 & 11,5 & 4,5 & 4,5 & 11,5 & 4,5 & 11,5 & 11,5 & 4,5 & 8 & 6 & 60 \\
\hline B & 5,5 & 5,5 & 5,5 & 5,5 & 5,5 & 12,5 & 5,5 & 5,5 & 12,5 & 5,5 & 5,5 & 12,5 & 12,5 & 5,5 & 10 & 4 & 88 \\
\hline C & 12,5 & 5,5 & 5,5 & 12,5 & 5,5 & 5,5 & 5,5 & 5,5 & 5,5 & 5,5 & 5,5 & 12,5 & 12,5 & 5,5 & 10 & 4 & 88 \\
\hline D & 4 & 11 & 11 & 11 & 4 & 4 & 11 & 4 & 11 & 11 & 4 & 11 & 4 & 4 & 7 & 7 & 56 \\
\hline E & 5,5 & 5,5 & 5,5 & 12,5 & 5,5 & 5,5 & 12,5 & 5,5 & 12,5 & 5,5 & 5,5 & 12,5 & 5,5 & 5,5 & 10 & 4 & 88 \\
\hline $\mathrm{F}$ & 5,5 & 5,5 & 5,5 & 12,5 & 5,5 & 5,5 & 5,5 & 5,5 & 12,5 & 12,5 & 5,5 & 12,5 & 5,5 & 5,5 & 10 & 4 & 88 \\
\hline G & 5,5 & 5,5 & 5,5 & 12,5 & 5,5 & 5,5 & 5,5 & 5,5 & 12,5 & 12,5 & 5,5 & 5,5 & 12,5 & 5,5 & 10 & 4 & 88 \\
\hline $\mathrm{H}$ & 5,5 & 5,5 & 5,5 & 12,5 & 5,5 & 5,5 & 5,5 & 5,5 & 12,5 & 12,5 & 5,5 & 12,5 & 5,5 & 5,5 & 10 & 4 & 88 \\
\hline 1 & 5,5 & 12,5 & 5,5 & 5,5 & 5,5 & 5,5 & 12,5 & 5,5 & 12,5 & 5,5 & 5,5 & 12,5 & 5,5 & 5,5 & 10 & 4 & 88 \\
\hline J & 5,5 & 5,5 & 12,5 & 5,5 & 5,5 & 5,5 & 5,5 & 5,5 & 12,5 & 12,5 & 5,5 & 12,5 & 5,5 & 5,5 & 10 & 4 & 88 \\
\hline K & 5,5 & 5,5 & 5,5 & 12,5 & 5,5 & 5,5 & 5,5 & 5,5 & 12,5 & 12,5 & 5,5 & 5,5 & 5,5 & 12,5 & 10 & 4 & 88 \\
\hline $\mathrm{L}$ & 5 & 5 & 5 & 12 & 5 & 5 & 12 & 5 & 12 & 12 & 12 & 5 & 5 & 5 & 9 & 5 & 70 \\
\hline$R=\sum$ ranks & 77 & 77 & 77 & 126 & 63 & 70 & 98 & 63 & 133 & 119 & 70 & 126 & 91 & 70 & & $\sum T=$ & 973 \\
\hline$X=\bar{R}-\bar{x}$ & $-13,0$ & $-13,0$ & $-13,0$ & 36,0 & $-27,0$ & $-20,0$ & 8,0 & $-27,0$ & 43,0 & 29,0 & $-20,0$ & 36,0 & 1,0 & $-20,0$ & & & \\
\hline$Y=X^{\wedge} 2$ & 169,00 & 169,00 & 169,00 & 1296,00 & 729,00 & 400,00 & 64,00 & 729,00 & 1849,00 & 841,00 & 400,00 & 1296,00 & 1,00 & 400,00 & & & \\
\hline & & & & & $\begin{array}{l}\mathrm{n}= \\
\mathrm{m}=\end{array}$ & $\begin{array}{l}14 \\
12 \\
\end{array}$ & $\begin{array}{l}\overline{\mathbf{x}}= \\
\mathrm{S}=\end{array}$ & $\begin{array}{r}90,0 \\
8512,0 \\
\end{array}$ & $\begin{array}{l}w= \\
x 2=\end{array}$ & $\begin{array}{r}0,404 \\
62,980 \\
\end{array}$ & & & & & & & \\
\hline
\end{tabular}

Os cálculos indicaram, face aos valores obtidos para o coeficiente de concordância W $(0,299$ para as barreiras e 0,404 para os benefícios), que havia grau de concordância baixo entre os painelistas no caso das barreiras e grau moderado no caso dos benefícios, adotadas as faixas sugeridas por Schmidt (op. cit.). Ambos os testes de $\chi^{2}$ mostraram que W tinha significância em nível $p=0,00001$.

Ressalte-se que estas listas coletivas ainda não representavam rankings, pois, neste ciclo, os painelistas apenas fizeram a escolha das barreiras e benefícios mais relevantes, sem, contudo, promover qualquer ordenação. Portanto, este ciclo permitiu somente que fossem eliminadas seis barreiras e quatro benefícios considerados menos relevantes pelo grupo de painelistas. Essas barreiras e benefícios eliminados estão com seus respectivos pesos, nas listas coletivas das Tabelas 1 e 2, marcados com um fundo de cor cinza.

\subsubsection{Respostas Relativas aos Riscos}

No que diz respeito aos riscos, objeto das duas últimas perguntas deste questionário, a compilação e interpretação das indicações feitas pelos painelistas levou à obtenção de uma lista compreendendo 15 riscos distintos, cuja relação, com as respectivas descrições já ajustadas, está apresentada no Quadro 14. 


\section{Quadro 14 - Riscos Potenciais Decorrentes da Adoção da Computação em Nuvem Não Privada Indicados pelos Painelistas}

No. Enunciado

R1 Falta de privacidade: baixo grau de confidencialidade e deficiências de isolamento no ambiente da nuvem, possibilitando acessos indevidos e/ou adulteração de dados e/ou aplicativos de consumidores

R2 Erros: falhas que implicam na necessidade de reprocessar rotinas e/ou recuperar dados

R3 Suporte inadequado: falhas de natureza diversa no serviço de suporte, tais como pessoal mal preparado, gargalos no atendimento, indisponibilidade do serviço etc.

R4 Baixo desempenho: desempenho insatisfatório dos serviços contratados (devido a picos de demanda, balanceamento inadequado, subdimensionamento dos recursos, alta latência de rede e outros fatores assemelhados), levando ao descumprimento dos SLA's

R5 Dificuldade para escalar: demora excessiva ou dificuldades do provedor para provisionar e/ou liberar recursos da nuvem

R6 Indisponibilidade: interrupção temporária dos serviços em decorrência de problemas técnicos ou de ordem diversa de parte do provedor

R7 Não-continuidade: interrupção definitiva da prestação dos serviços pelo provedor

R8 Aprisionamento: dificuldade significativa ou, no limite, impossibilidade de trocar de provedor, devido a particularidades do ambiente e/ou aspectos contratuais

R9 Baixa interoperabilidade: dificuldade significativa ou, no limite, impossibilidade de intercambiar dados e/ou aplicativos entre distintos provedores

R10 Governança inadequada: modelo de governança adotado pelo provedor possui lacunas e/ou pontos falhos e não atende às necessidades impostas pelos contratos acordados com seus clientes

R11 Incapacidade: baixa capacidade e/ou inexperiência do provedor para prestar serviços da natureza dos ofertados em ambientes de computação em nuvem

R12 Imaturidade do modelo: baixa maturidade do modelo de prestação de serviços em nuvem por ser muito recente, podendo gerar exposição indevida para os gestores de TI dos clientes

R13 Mentalidade invariante: dificuldade do provedor em adotar uma postura distinta frente às necessidades e demandas por serviços de diferentes graus de relevância para os consumidores (por exemplo, serviços de agenda e correio eletrônico versus ERP)

R14 Dificuldade para integrar: dificuldade significativa ou, no limite, impossibilidade de integrar diferentes aplicativos de um mesmo ou de distintos fornecedores

R15 Falta de visibilidade: baixa visibilidade ou, no limite, ausência total de visibilidade acerca dos ativos e recursos disponibilizados pelo provedor

\subsection{Realização do Ciclo 3 do Painel}

Este ciclo abrangeu o preparo e envio do terceiro questionário relacionado ao tema da pesquisa e a posterior tabulação e análise das respostas obtidas.

O questionário deste ciclo foi composto por quatro perguntas, ainda uma vez finalizando com uma questão destinada a colher comentários dos painelistas. As duas primeiras questões 
direcionaram os painelistas a propor um ranking de barreiras e um de benefícios, a partir das indicações mais frequentes presentes na consolidação das respostas dadas às questões 1 e 2 do ciclo anterior. A terceira questão direcionou os painelistas a indicar os 12 riscos mais relevantes, dentre os presentes na consolidação das respostas dadas às questões 3 e 4 do ciclo anterior. O texto na íntegra das perguntas que compuseram este questionário está apresentado no Apêndice 2.

Este questionário foi enviado aos 12 painelistas remanescentes, tendo sido excluídos aqueles que não enviaram suas respostas na rodada anterior. Foram recebidas respostas dos três acadêmicos e de oito profissionais de TI, perfazendo um total de 11 .

\subsubsection{Preparo da Questão Relativa aos Riscos}

Antes da elaboração da lista de riscos a ser inserida neste questionário, foi feito um confronto entre os 15 riscos relacionados no Quadro 14 e aqueles constantes do Quadro 8, resultantes da consolidação mencionada no tópico 2.2.5 deste documento. Este confronto permitiu concluir que todos os riscos citados pelos painelistas coincidiam com parte dos extraídos das referências bibliográficas (feitas as adequadas interpretações das definições) e identificar cinco riscos relevantes não indicados pelos painelistas, quais sejam: (a) não-conformidade, (b) licenciamento de software, (c) má reputação do provedor, (d) deficiência de integridade e (e) vulnerabilidade a ataques por saturação. Estes riscos foram numerados, respectivamente, como R16 a R20 e acrescentados à lista dos indicados, de modo a compor a questão específica sobre este tema neste questionário.

\subsubsection{Respostas Relativas aos Riscos}

Apesar de solicitados a indicar 12 riscos, nem todos os painelistas o fizeram, tendo sido indicados apenas 11 e dez elementos em alguns casos.

De todo modo, de posse das respostas, foi elaborada uma lista consolidada com os 12 riscos mais indicados, representativos, portanto, da opinião coletiva do grupo de painelistas. Para obter estes 12 riscos, foi aplicado, uma vez mais, o método de ordenação escolhido, proposto por Kendall e Smith (op. cit.), com a variante destinada a equacionar a questão dos empates recomendada por Kendall (op. cit.). 
Dado que neste ciclo a lista também não está ordenada pelos painelistas, mas apenas estão indicados os 12 riscos mais relevantes, a cada um deles o método recomenda ser atribuído o peso 1 e, aos demais não selecionados, o peso 13, caracterizando empates tanto entre os selecionados quanto entre os não selecionados. Para eliminar os empates, a variante do método propõe substituir os pesos iguais pela média aritmética das posições por eles ocupadas. Neste caso, como os empates entre os 12 elementos indicados se dão nas posições de 1 a 12, os pesos destes elementos são substituídos por 6,5, valor que corresponde à média da soma dos valores de 1 a 12; para os elementos não indicados, cujas posições vão de 13 a 20, o peso médio é 16,5. Para as listas individuais cujas indicações contemplam apenas 11 ou dez elementos, os pesos atribuídos aos itens empatados são diferentes destes, pois as médias são outras.

Os pesos atribuídos aos elementos de todas as listas individuais elaboradas pelos painelistas estão apresentados na Tabela 3, a qual, adicionalmente, contém os resultados dos cálculos efetuados para a obtenção da lista ordenada coletiva. As fórmulas de cálculo envolvidas, bem como o significado das variáveis constantes desta tabela, constam, conforme já mencionado, do Apêndice 4.

Tabela 3 - Riscos Mais Relevantes (Opinião dos Painelistas)

\begin{tabular}{|c|c|c|c|c|c|c|c|c|c|c|c|c|c|c|c|c|c|c|c|c|c|c|c|}
\hline \multirow{2}{*}{ Painelistas } & \multicolumn{20}{|c|}{ Riscos } & \multicolumn{3}{|c|}{ Efeito dos Empates } \\
\hline & R1 & R2 & R3 & R4 & R5 & R6 & R7 & R8 & R9 & R10 & R11 & R12 & R13 & R14 & R15 & R16 & R17 & R18 & R19 & R20 & $\mathrm{t} 1$ & t2 & $T$ \\
\hline A & 16,5 & 6,5 & 6,5 & 6,5 & 6,5 & 6,5 & 6,5 & 6,5 & 6,5 & 16,5 & 16,5 & 16,5 & 16,5 & 16,5 & 16,5 & 6,5 & 6,5 & 6,5 & 16,5 & 6,5 & 12 & 8 & 185 \\
\hline$B$ & 6,5 & 16,5 & 16,5 & 6,5 & 6,5 & 6,5 & 6,5 & 6,5 & 16,5 & 16,5 & 6,5 & 6,5 & 6,5 & 6,5 & 16,5 & 16,5 & 16,5 & 6,5 & 16,5 & 6,5 & 12 & 8 & 185 \\
\hline C & 16,5 & 6,5 & 6,5 & 16,5 & 6,5 & 16,5 & 16,5 & 6,5 & 6,5 & 6,5 & 6,5 & 6,5 & 6,5 & 6,5 & 16,5 & 16,5 & 16,5 & 16,5 & 6,5 & 6,5 & 12 & 8 & 185 \\
\hline$D$ & 16,5 & 6,5 & 6,5 & 6,5 & 6,5 & 6,5 & 16,5 & 16,5 & 6,5 & 16,5 & 6,5 & 6,5 & 16,5 & 6,5 & 6,5 & 16,5 & 6,5 & 6,5 & 16,5 & 16,5 & 12 & 8 & 185 \\
\hline $\mathrm{E}$ & 5,5 & 15,5 & 5,5 & 5,5 & 5,5 & 5,5 & 5,5 & 5,5 & 15,5 & 5,5 & 5,5 & 5,5 & 15,5 & 15,5 & 15,5 & 15,5 & 15,5 & 15,5 & 15,5 & 15,5 & 10 & 10 & 165 \\
\hline $\mathrm{F}$ & 6,5 & 6,5 & 6,5 & 16,5 & 16,5 & 16,5 & 16,5 & 16,5 & 6,5 & 16,5 & 16,5 & 16,5 & 6,5 & 6,5 & 6,5 & 6,5 & 6,5 & 6,5 & 6,5 & 6,5 & 12 & 8 & 185 \\
\hline G & 6 & 16 & 16 & 6 & 16 & 6 & 16 & 6 & 16 & 6 & 6 & 6 & 6 & 16 & 6 & 6 & 16 & 6 & 16 & 16 & 11 & 9 & 170 \\
\hline H & 6,5 & 16,5 & 16,5 & 6,5 & 6,5 & 6,5 & 6,5 & 6,5 & 16,5 & 6,5 & 16,5 & 16,5 & 16,5 & 6,5 & 16,5 & 6,5 & 6,5 & 6,5 & 6,5 & 16,5 & 12 & 8 & 185 \\
\hline 1 & 16,5 & 16,5 & 6,5 & 6,5 & 16,5 & 6,5 & 6,5 & 6,5 & 6,5 & 16,5 & 6,5 & 6,5 & 16,5 & 6,5 & 6,5 & 16,5 & 16,5 & 6,5 & 6,5 & 16,5 & 12 & 8 & 185 \\
\hline J & 6 & 16 & 16 & 6 & 16 & 6 & 6 & 16 & 6 & 6 & 6 & 6 & 16 & 16 & 6 & 16 & 16 & 16 & 6 & 6 & 11 & 9 & 170 \\
\hline K & 16 & 6 & 6 & 6 & 16 & 16 & 6 & 6 & 6 & 16 & 16 & 6 & 6 & 6 & 16 & 6 & 6 & 16 & 16 & 16 & 11 & 9 & 170 \\
\hline$R=\sum$ ranks & 119 & 129 & 109 & 89 & 119 & 99 & 109 & 99 & 109 & 129 & 109 & 99 & 129 & 109 & 129 & 129 & 129 & 109 & 129 & 129 & \multirow{3}{*}{\multicolumn{3}{|c|}{$\Sigma T=1970$}} \\
\hline$X=R-\bar{x}$ & 3,5 & 13,5 & $-6,5$ & $-26,5$ & 3,5 & $-16,5$ & $-6,5$ & $-16,5$ & $-6,5$ & 13,5 & $-6,5$ & $-16,5$ & 13,5 & $-6,5$ & 13,5 & 13,5 & 13,5 & $-6,5$ & 13,5 & 13,5 & & & \\
\hline$Y=X^{\wedge} 2$ & 12,25 & 182,25 & 42,25 & 702,25 & 12,25 & 272,25 & 42,25 & 272,25 & 42,25 & 182,25 & 42,25 & 272,25 & 182,25 & 42,25 & 182,25 & 182,25 & 182,25 & 42,25 & 182,25 & 182,25 & & & \\
\hline & & & & & & & & $\begin{array}{l}\mathrm{n}= \\
\mathrm{m}=\end{array}$ & $\begin{array}{l}20 \\
11\end{array}$ & $\begin{array}{l}\overline{\mathbf{x}}= \\
\mathrm{S}=\end{array}$ & $\begin{array}{r}115,5 \\
3255,0\end{array}$ & $\begin{array}{l}W= \\
x 2=\end{array}$ & \begin{tabular}{r|}
0,055 \\
11,571
\end{tabular} & & & & & & & & & & \\
\hline
\end{tabular}

Os cálculos indicaram, face ao valor 0,055 obtido para o coeficiente de concordância W, que, neste ciclo, havia um grau de concordância ainda muito baixo entre os painelistas, adotadas as faixas sugeridas por Schmidt (op. cit.). O teste de $\chi^{2}$ mostrou que W tinha significância muito baixa $(p>>0,1)$ e este fato sugeria que tinha que ser buscada, nos ciclos seguintes, uma 
concordância maior entre os painelistas, mas não invalidou a escolha, neste passo, dos riscos mais relevantes.

Ressalte-se, aqui também, que esta lista coletiva ainda não representava um ranking, pois, neste ciclo, os painelistas apenas escolheram os riscos mais relevantes, sem, todavia, promover qualquer ordenação. Portanto, este ciclo permitiu somente que fossem eliminados pelos painelistas oito riscos considerados menos relevantes, riscos esses que estão com seus respectivos pesos, na lista coletiva da Tabela 3, marcados com um fundo de cor cinza.

\subsubsection{Respostas Relativas às Barreiras}

Ao responder a este questionário, na sequência, cada painelista indicou um ranking para barreiras e a tabulação das respostas foi feita com o objetivo de obter o ranking consolidado. A Tabela 4 apresenta os rankings de barreiras, os individuais e o coletivo, este último refletindo a opinião consolidada do grupo. A linha da tabela marcada com um fundo de cor cinza indica as posições das barreiras no ranking consolidado.

$\mathrm{O}$ coeficiente de concordância W tinha um valor equivalente a 0,227 , significando que o ranking consolidado, adotadas as faixas sugeridas por Schmidt (op. cit.), expressava a existência de um grau de concordância baixo entre os painelistas. $O$ teste de $\chi^{2}$ mostrava que W tinha significância em nível $p=0,01$.

Tabela 4 - Rankings das Barreiras Mais Relevantes

\begin{tabular}{|c|c|c|c|c|c|c|c|c|c|c|}
\hline \multirow{2}{*}{ Painelistas } & \multicolumn{10}{|c|}{ Barreiras } \\
\hline & B1 & B2 & B3 & B5 & B6 & B9 & B10 & B11 & B15 & B16 \\
\hline A & 1 & 2 & 8 & 5 & 6 & 4 & 7 & 9 & 10 & 3 \\
\hline$B$ & 1 & 2 & 5 & 6 & 7 & 8 & 9 & 3 & 10 & 4 \\
\hline C & 1 & 2 & 8 & 7 & 3 & 5 & 6 & 4 & 9 & 10 \\
\hline$D$ & 8 & 9 & 10 & 7 & 6 & 5 & 4 & 3 & 2 & 1 \\
\hline$E$ & 2 & 3 & 10 & 4 & 7 & 6 & 8 & 5 & 9 & 1 \\
\hline$F$ & 4 & 3 & 6 & 2 & 9 & 5 & 7 & 8 & 10 & 1 \\
\hline G & 5 & 4 & 7 & 8 & 10 & 6 & 1 & 2 & 9 & 3 \\
\hline $\mathrm{H}$ & 9 & 3 & 4 & 5 & 7 & 6 & 8 & 10 & 1 & 2 \\
\hline 1 & 9 & 2 & 3 & 4 & 5 & 8 & 7 & 6 & 10 & 1 \\
\hline J & 10 & 8 & 7 & 5 & 6 & 4 & 3 & 2 & 9 & 1 \\
\hline $\mathrm{K}$ & 1 & 5 & 6 & 2 & 4 & 3 & 8 & 9 & 10 & 7 \\
\hline$R=\sum$ ranks & 51 & 43 & 74 & 55 & 70 & 60 & 68 & 61 & 89 & 34 \\
\hline$X=R-\bar{x}$ & $-9,5$ & $-17,5$ & 13,5 & $-5,5$ & 9,5 & $-0,5$ & 7,5 & 0,5 & 28,5 & $-26,5$ \\
\hline$Y=X^{\wedge} 2$ & 90,25 & 306,25 & 182,25 & 30,25 & 90,25 & 0,25 & 56,25 & 0,25 & 812,25 & 702,25 \\
\hline \multirow[t]{3}{*}{ Posição } & 3 & 2 & 9 & 4 & 8 & 5 & 7 & 6 & 10 & 1 \\
\hline & & & $n=$ & 10 & $\overline{\mathbf{x}}=$ & 60,5 & $\mathbf{W}=$ & 0,227 & & \\
\hline & & & $\mathrm{m}=$ & 11 & $S=$ & 2270,5 & $x 2=$ & 22,517 & & \\
\hline
\end{tabular}


Desdobrando em dois subconjuntos as respostas relativas ao ordenamento das barreiras, têmse em separado os rankings consolidados dos acadêmicos e dos profissionais de TI, os quais estão apresentados nas Tabelas 5 e 6.

Tabela 5 - Rankings das Barreiras Mais Relevantes (Acadêmicos)

\begin{tabular}{|c|c|c|c|c|c|c|c|c|c|c|}
\hline \multirow{2}{*}{ Painelistas } & \multicolumn{10}{|c|}{ Barreiras } \\
\hline & B1 & B2 & B3 & B5 & B6 & B9 & B10 & B11 & B15 & B16 \\
\hline A & 1 & 2 & 8 & 5 & 6 & 4 & 7 & 9 & 10 & 3 \\
\hline$B$ & 1 & 2 & 5 & 6 & 7 & 8 & 9 & 3 & 10 & 4 \\
\hline$C$ & 1 & 2 & 8 & 7 & 3 & 5 & 6 & 4 & 9 & 10 \\
\hline $\mathrm{R}=\sum$ ranks & 3 & 6 & 21 & 18 & 16 & 17 & 22 & 16 & 29 & 17 \\
\hline$X=R-\bar{x}$ & $-13,5$ & $-10,5$ & 4,5 & 1,5 & $-0,5$ & 0,5 & 5,5 & $-0,5$ & 12,5 & 0,5 \\
\hline$Y=X^{\wedge} 2$ & 182,25 & 110,25 & 20,25 & 2,25 & 0,25 & 0,25 & 30,25 & 0,25 & 156,25 & 0,25 \\
\hline Posição & 1 & 2 & 8 & 7 & 3 & 5 & 9 & 3 & 10 & 5 \\
\hline & & & $\begin{array}{r}n= \\
m=\end{array}$ & $\begin{array}{c}10 \\
3\end{array}$ & $\begin{array}{l}\overline{\mathbf{x}}= \\
\mathbf{S}=\end{array}$ & $\begin{array}{r}16,5 \\
502,5\end{array}$ & $\begin{array}{l}w= \\
\chi 2=\end{array}$ & $\begin{array}{r}0,677 \\
18,273\end{array}$ & & \\
\hline
\end{tabular}

Tabela 6 - Rankings das Barreiras Mais Relevantes (Profissionais de TI)

\begin{tabular}{|c|c|c|c|c|c|c|c|c|c|c|}
\hline \multirow{2}{*}{ Painelistas } & \multicolumn{10}{|c|}{ Barreiras } \\
\hline & B1 & B2 & B3 & B5 & B6 & B9 & B10 & B11 & B15 & B16 \\
\hline $\mathrm{D}$ & 8 & 9 & 10 & 7 & 6 & 5 & 4 & 3 & 2 & 1 \\
\hline$E$ & 2 & 3 & 10 & 4 & 7 & 6 & 8 & 5 & 9 & 1 \\
\hline $\mathrm{F}$ & 4 & 3 & 6 & 2 & 9 & 5 & 7 & 8 & 10 & 1 \\
\hline G & 5 & 4 & 7 & 8 & 10 & 6 & 1 & 2 & 9 & 3 \\
\hline $\mathrm{H}$ & 9 & 3 & 4 & 5 & 7 & 6 & 8 & 10 & 1 & 2 \\
\hline 1 & 9 & 2 & 3 & 4 & 5 & 8 & 7 & 6 & 10 & 1 \\
\hline J & 10 & 8 & 7 & 5 & 6 & 4 & 3 & 2 & 9 & 1 \\
\hline K & 1 & 5 & 6 & 2 & 4 & 3 & 8 & 9 & 10 & 7 \\
\hline$R=\sum$ ranks & 48 & 37 & 53 & 37 & 54 & 43 & 46 & 45 & 60 & 17 \\
\hline$X=\bar{R}-\bar{X}$ & 4,0 & $-7,0$ & 9,0 & $-7,0$ & 10,0 & $-1,0$ & 2,0 & 1,0 & 16,0 & $-27,0$ \\
\hline$Y=X^{\wedge} 2$ & 16 & 49 & 81 & 49 & 100 & 1 & 4 & 1 & 256 & 729 \\
\hline Posição & 7 & 2 & 8 & 2 & 9 & 4 & 6 & 5 & 10 & 1 \\
\hline & & & $\begin{array}{r}n= \\
m=\end{array}$ & $\begin{array}{c}10 \\
8 \\
\end{array}$ & $\begin{array}{r}\overline{\mathbf{x}}= \\
\mathrm{S}=\end{array}$ & $\begin{array}{r}44,0 \\
1286,0\end{array}$ & $\begin{array}{l}w= \\
\chi 2=\end{array}$ & $\begin{array}{r}0,244 \\
17,536 \\
\end{array}$ & & \\
\hline
\end{tabular}

A análise destas duas últimas tabelas mostra que, para os acadêmicos, o ranking obtido era relativamente diferente do geral, com três coincidências de posições (ranks das barreiras B2, B9 e B15), uma posição próxima apenas (ranks 8 e 9 para a barreira B3) e quatro discrepâncias significativas (ranks 7 e 4 para a barreira B5, ranks 3 e 8 para a barreira B6, ranks 3 e 6 para a barreira B11 e ranks 5 e 1 para a barreira B16). Já o ranking dos profissionais de TI era mais semelhante ao geral, com também três coincidências de posições (ranks das barreiras B2, B15 e B16), mas cinco posições próximas e somente uma discrepância mais significativa (ranks 7 e 3 para a barreira B1). No caso dos acadêmicos, havia um alto grau de concordância de opiniões acerca das barreiras mais relevantes, adotadas as faixas sugeridas por Schmidt (op. cit.), pois o coeficiente de concordância foi a 0,677 , ao 
passo que entre os profissionais de TI o grau de concordância era tão baixo quanto o verificado para o grupo como um todo. Em ambos os casos, o teste de $\chi^{2}$ mostrava que W tinha significância em nível $p=0,05$.

\subsubsection{Respostas Relativas aos Benefícios}

No que diz respeito aos benefícios, a Tabela 7 apresenta seus rankings individuais e o coletivo, também obtidos a partir das respostas a este questionário. A linha da tabela marcada com um fundo de cor cinza indica as posições dos benefícios no ranking consolidado.

Neste caso, o coeficiente de concordância tinha um valor equivalente a 0,144 , significando que também este ranking consolidado expressava um grau de concordância baixo entre os painelistas, adotadas as faixas sugeridas por Schmidt (op. cit.). O teste de $\chi^{2}$ mostrava que W tinha significância em nível $p=0,1$.

Tabela 7 - Rankings dos Benefícios Mais Relevantes

\begin{tabular}{|c|c|c|c|c|c|c|c|c|c|c|}
\hline \multirow{2}{*}{ Painelistas } & \multicolumn{10}{|c|}{ Benefícios } \\
\hline & V1 & V2 & V3 & V5 & V6 & v7 & V8 & V11 & V13 & V14 \\
\hline A & 2 & 3 & 9 & 4 & 5 & 7 & 8 & 10 & 6 & 1 \\
\hline B & 3 & 2 & 4 & 5 & 1 & 6 & 7 & 8 & 10 & 9 \\
\hline C & 10 & 8 & 6 & 3 & 4 & 5 & 2 & 1 & 7 & 9 \\
\hline D & 4 & 3 & 2 & 9 & 8 & 10 & 7 & 1 & 6 & 5 \\
\hline$E$ & 2 & 7 & 3 & 4 & 5 & 10 & 9 & 8 & 6 & 1 \\
\hline$F$ & 1 & 2 & 3 & 4 & 6 & 10 & 5 & 9 & 8 & 7 \\
\hline G & 1 & 7 & 5 & 4 & 2 & 3 & 6 & 10 & 8 & 9 \\
\hline $\mathrm{H}$ & 10 & 1 & 2 & 7 & 5 & 4 & 6 & 8 & 3 & 9 \\
\hline 1 & 6 & 9 & 10 & 2 & 3 & 8 & 4 & 5 & 1 & 7 \\
\hline J & 5 & 7 & 6 & 4 & 3 & 9 & 10 & 2 & 1 & 8 \\
\hline $\mathrm{K}$ & 5 & 2 & 3 & 4 & 1 & 6 & 7 & 8 & 9 & 10 \\
\hline$R=\sum$ ranks & 49 & 51 & 53 & 50 & 43 & 78 & 71 & 70 & 65 & 75 \\
\hline$X=R-\bar{x}$ & $-11,5$ & $-9,5$ & $-7,5$ & $-10,5$ & $-17,5$ & 17,5 & 10,5 & 9,5 & 4,5 & 14,5 \\
\hline$Y=X^{\wedge} 2$ & 132,25 & 90,25 & 56,25 & 110,25 & 306,25 & 306,25 & 110,25 & 90,25 & 20,25 & 210,25 \\
\hline Posição & 2 & 4 & 5 & 3 & 1 & 10 & 8 & 7 & 6 & 9 \\
\hline & & & $\begin{array}{r}n= \\
m=\end{array}$ & $\begin{array}{l}10 \\
11 \\
\end{array}$ & $\begin{array}{l}\overline{\mathbf{x}}= \\
\mathrm{S}=\end{array}$ & $\begin{array}{r}60,5 \\
1432,5 \\
\end{array}$ & $\begin{array}{l}w= \\
\times 2=\end{array}$ & $\begin{array}{r}0,144 \\
14,207 \\
\end{array}$ & & \\
\hline
\end{tabular}

Desdobrando, da mesma forma, em dois subconjuntos as respostas relativas ao ordenamento dos benefícios, têm-se em separado os rankings consolidados dos acadêmicos e dos profissionais de TI, os quais estão apresentados nas Tabelas 8 e 9. 
Tabela 8 - Rankings dos Benefícios Mais Relevantes (Acadêmicos)

\begin{tabular}{|c|c|c|c|c|c|c|c|c|c|c|}
\hline \multirow{2}{*}{ Painelistas } & \multicolumn{10}{|c|}{ Benefícios } \\
\hline & V1 & V2 & V3 & V5 & V6 & V7 & V8 & V11 & V13 & V14 \\
\hline A & 2 & 3 & 9 & 4 & 5 & 7 & 8 & 10 & 6 & 1 \\
\hline B & 3 & 2 & 4 & 5 & 1 & 6 & 7 & 8 & 10 & 9 \\
\hline C & 10 & 8 & 6 & 3 & 4 & 5 & 2 & 1 & 7 & 9 \\
\hline $\mathrm{R}=\sum$ ranks & 15 & 13 & 19 & 12 & 10 & 18 & 17 & 19 & 23 & 19 \\
\hline$X=R-\bar{x}$ & $-1,5$ & $-3,5$ & 2,5 & $-4,5$ & $-6,5$ & 1,5 & 0,5 & 2,5 & 6,5 & 2,5 \\
\hline$Y=X^{\wedge} 2$ & 2,25 & 12,25 & 6,25 & 20,25 & 42,25 & 2,25 & 0,25 & 6,25 & 42,25 & 6,25 \\
\hline Posição & 4 & 3 & 7 & 2 & 1 & 6 & 5 & 7 & 10 & 7 \\
\hline & & & $\begin{array}{r}n= \\
m=\end{array}$ & $\begin{array}{c}10 \\
3\end{array}$ & $\begin{array}{l}\overline{\mathbf{x}}= \\
\mathrm{S}=\end{array}$ & $\begin{array}{r}16,5 \\
140,5\end{array}$ & $\begin{array}{l}W= \\
x^{2}=\end{array}$ & $\begin{array}{l}0,189 \\
5,109\end{array}$ & & \\
\hline
\end{tabular}

Tabela 9 - Rankings dos Benefícios Mais Relevantes (Profissionais de TI)

\begin{tabular}{|c|c|c|c|c|c|c|c|c|c|c|}
\hline \multirow{2}{*}{ Painelistas } & \multicolumn{10}{|c|}{ Benefícios } \\
\hline & V1 & V2 & V3 & V5 & V6 & v7 & V8 & V11 & V13 & V14 \\
\hline D & 4 & 3 & 2 & 9 & 8 & 10 & 7 & 1 & 6 & 5 \\
\hline$E$ & 2 & 7 & 3 & 4 & 5 & 10 & 9 & 8 & 6 & 1 \\
\hline $\mathrm{F}$ & 1 & 2 & 3 & 4 & 6 & 10 & 5 & 9 & 8 & 7 \\
\hline G & 1 & 7 & 5 & 4 & 2 & 3 & 6 & 10 & 8 & 9 \\
\hline $\mathrm{H}$ & 10 & 1 & 2 & 7 & 5 & 4 & 6 & 8 & 3 & 9 \\
\hline 1 & 6 & 9 & 10 & 2 & 3 & 8 & 4 & 5 & 1 & 7 \\
\hline J & 5 & 7 & 6 & 4 & 3 & 9 & 10 & 2 & 1 & 8 \\
\hline K & 5 & 2 & 3 & 4 & 1 & 6 & 7 & 8 & 9 & 10 \\
\hline $\mathrm{R}=\sum$ ranks & 34 & 38 & 34 & 38 & 33 & 60 & 54 & 51 & 42 & 56 \\
\hline$X=R-\bar{x}$ & $-10,0$ & $-6,0$ & $-10,0$ & $-6,0$ & $-11,0$ & 16,0 & 10,0 & 7,0 & $-2,0$ & 12,0 \\
\hline$Y=X^{\wedge} 2$ & 100,00 & 36,00 & 100,00 & 36,00 & 121,00 & 256,00 & 100,00 & 49,00 & 4,00 & 144,00 \\
\hline \multirow[t]{3}{*}{ Posição } & 2 & 4 & 2 & 4 & 1 & 10 & 8 & 7 & 6 & 9 \\
\hline & & & $\mathrm{n}=$ & 10 & $\overline{\mathbf{x}}=$ & 44,0 & $\mathbf{W}=$ & 0,179 & & \\
\hline & & & $m=$ & 8 & $S=$ & 946,0 & $x 2=$ & 12,900 & & \\
\hline
\end{tabular}

A análise destas duas últimas tabelas mostra que, no caso dos benefícios, verificava-se uma situação análoga à das barreiras. O ranking obtido para os acadêmicos era também relativamente diferente do geral, com apenas duas coincidências de posições (ranks dos benefícios V6 e V11), duas posições próximas (ranks 3 e 4 para o benefício V2 e ranks 2 e 3 para o benefício V5) e três discrepâncias significativas (ranks 6 e 10 para o benefício V7, ranks 5 e 8 para o benefício V8 e ranks 10 e 6 para o benefício V13). Já o ranking dos profissionais de TI era quase idêntico ao geral, com oito coincidências de posições, uma posição próxima (ranks 4 e 3 para o benefício V5) e apenas uma discrepância significativa (ranks 2 e 5 para o benefício V3). Entretanto, as concordâncias de opiniões permaneciam em grau baixo em ambos os casos, adotadas as faixas sugeridas por Schmidt (op. cit.), pois o coeficiente de concordância $\mathrm{W}$ foi a 0,189 para os acadêmicos e 0,179 para os profissionais de TI. O teste de $\chi^{2}$, por seu turno, indicava que, em ambos os casos, a significância de $\mathrm{W}$ era muito baixa $(p>>0,1)$, reforçando a necessidade de se aguardar um próximo ciclo para verificar as variações dos valores de $\mathrm{W}$ e poder evoluir nas conclusões. 


\subsection{Realização do Ciclo 4 do Painel}

Este ciclo abrangeu o preparo e envio do quarto questionário relacionado ao tema da pesquisa e a posterior tabulação e análise das respostas obtidas.

Este questionário compreendeu quatro perguntas, sendo a última, como de praxe, destinada a colher comentários gerais dos painelistas. A primeira questão visou obter dos painelistas a proposição de um ranking de riscos, a partir das indicações mais frequentes presentes na consolidação das respostas dadas à questão 3 do ciclo anterior. As duas outras questões visaram revisar os rankings de barreiras e benefícios estabelecidos na rodada anterior. $\mathrm{O}$ texto na íntegra das perguntas que compuseram este questionário complementa o Apêndice 2.

Este questionário foi enviado aos 11 painelistas remanescentes, tendo sido excluído aquele que não enviou suas respostas na rodada anterior. Todos os painelistas responderam.

\subsubsection{Respostas Relativas aos Riscos}

Ao responder a este questionário, cada painelista indicou um ranking para riscos e a tabulação das respostas foi feita com o objetivo de se obter o ranking consolidado. A Tabela 10 apresenta os rankings de riscos, os individuais e o coletivo, este último refletindo a opinião consolidada do grupo. A linha da tabela marcada com um fundo de cor cinza indica as posições dos riscos no ranking consolidado.

Tabela 10 - Rankings dos Riscos Mais Relevantes

\begin{tabular}{|c|c|c|c|c|c|c|c|c|c|c|c|c|}
\hline \multirow{2}{*}{ Painelistas } & \multicolumn{12}{|c|}{ Riscos } \\
\hline & R1 & R3 & R4 & R5 & R6 & R7 & R8 & R9 & R11 & R12 & R14 & R18 \\
\hline A & 3 & 6 & 1 & 2 & 12 & 5 & 11 & 8 & 7 & 4 & 9 & 10 \\
\hline$B$ & 11 & 12 & 10 & 9 & 7 & 8 & 4 & 5 & 6 & 1 & 2 & 3 \\
\hline C & 3 & 7 & 8 & 5 & 6 & 10 & 11 & 12 & 4 & 2 & 1 & 9 \\
\hline D & 8 & 2 & 1 & 7 & 6 & 9 & 10 & 3 & 4 & 11 & 5 & 12 \\
\hline$E$ & 1 & 12 & 9 & 11 & 4 & 2 & 8 & 7 & 10 & 3 & 5 & 6 \\
\hline$F$ & 3 & 8 & 4 & 7 & 11 & 9 & 12 & 5 & 6 & 2 & 1 & 10 \\
\hline G & 3 & 8 & 5 & 6 & 11 & 10 & 12 & 4 & 7 & 2 & 1 & 9 \\
\hline $\mathrm{H}$ & 1 & 3 & 2 & 5 & 4 & 6 & 10 & 7 & 8 & 11 & 9 & 12 \\
\hline 1 & 4 & 8 & 3 & 7 & 11 & 10 & 12 & 5 & 6 & 2 & 1 & 9 \\
\hline J & 11 & 9 & 8 & 10 & 12 & 7 & 6 & 5 & 4 & 3 & 2 & 1 \\
\hline $\mathrm{K}$ & 3 & 7 & 4 & 8 & 11 & 10 & 12 & 5 & 6 & 1 & 2 & 9 \\
\hline $\mathrm{R}=\sum$ ranks & 51,0 & 82,0 & 55,0 & 77,0 & 95,0 & 86,0 & 108,0 & 66,0 & 68,0 & 42,0 & 38,0 & 90,0 \\
\hline$X=R-\bar{X}$ & $-20,5$ & 10,5 & $-16,5$ & 5,5 & 23,5 & 14,5 & 36,5 & $-5,5$ & $-3,5$ & $-29,5$ & $-33,5$ & 18,5 \\
\hline$Y=X^{\wedge} 2$ & 420,25 & 110,25 & 272,25 & 30,25 & 552,25 & 210,25 & 1332,25 & 30,25 & 12,25 & 870,25 & 1122,25 & 342,25 \\
\hline \multirow[t]{3}{*}{ Posição } & 3 & 8 & 4 & 7 & 11 & 10 & 12 & 5 & 6 & 2 & 1 & 9 \\
\hline & & & & $\mathrm{n}=$ & 12 & $\overline{\mathbf{x}}=$ & 71,5 & $\mathbf{W}=$ & 0,307 & & & \\
\hline & & & & $m=$ & 11 & $S=$ & 5305,0 & $\times 2=$ & 37,098 & & & \\
\hline
\end{tabular}


O coeficiente de concordância W é 0,307, significando que o ranking consolidado, adotadas as faixas sugeridas por Schmidt (op. cit.), expressa a existência de um grau de concordância moderado entre os painelistas. $\mathrm{O}$ teste de $\chi^{2}$ mostra que $\mathrm{W}$ tem significância em nível $p=$ 0,0001. Dado o grau de concordância obtido neste ciclo, entendeu-se que, para este tema, o painel poderia ser encerrado, assumindo-se este ranking consolidado como sendo o final.

Desdobrando também as respostas relativas ao ordenamento dos riscos em dois subconjuntos, têm-se em separado, uma vez mais, os rankings consolidados dos acadêmicos e dos profissionais de TI, os quais estão apresentados nas Tabelas 11 e 12.

Tabela 11 - Rankings dos Riscos Mais Relevantes (Acadêmicos)

\begin{tabular}{|c|c|c|c|c|c|c|c|c|c|c|c|c|}
\hline \multirow{2}{*}{ Painelistas } & \multicolumn{12}{|c|}{ Riscos } \\
\hline & $\mathbf{R} \mathbf{1}$ & $\mathbf{R 3}$ & R4 & R5 & R6 & R7 & R8 & $\mathbf{R 9}$ & R11 & R12 & R14 & R18 \\
\hline A & 3 & 6 & 1 & 2 & 12 & 5 & 11 & 8 & 7 & 4 & 9 & 10 \\
\hline B & 11 & 12 & 10 & 9 & 7 & 8 & 4 & 5 & 6 & 1 & 2 & 3 \\
\hline $\mathrm{C}$ & 3 & 7 & 8 & 5 & 6 & 10 & 11 & 12 & 4 & 2 & 1 & 9 \\
\hline $\mathrm{R}=\sum$ ranks & 17,0 & 25,0 & 19,0 & 16,0 & 25,0 & 23,0 & 26,0 & 25,0 & 17,0 & 7,0 & 12,0 & 22,0 \\
\hline$X=R-\bar{x}$ & $-2,5$ & 5,5 & $-0,5$ & $-3,5$ & 5,5 & 3,5 & 6,5 & 5,5 & $-2,5$ & $-12,5$ & $-7,5$ & 2,5 \\
\hline$Y=X^{\wedge} 2$ & 6,25 & 30,25 & 0,25 & 12,25 & 30,25 & 12,25 & 42,25 & 30,25 & 6,25 & 156,25 & 56,25 & 6,25 \\
\hline Posição & 4 & 9 & 6 & 3 & 9 & 8 & 12 & 9 & 4 & 1 & 2 & 7 \\
\hline & & & & $\begin{array}{r}n= \\
m=\end{array}$ & $\begin{array}{c}12 \\
3 \\
\end{array}$ & $\begin{array}{l}\overline{\mathbf{x}}= \\
\mathbf{S}=\end{array}$ & $\begin{array}{r}19,5 \\
389,0 \\
\end{array}$ & $\begin{array}{l}w= \\
x 2=\end{array}$ & $\begin{array}{l}0,302 \\
9,974 \\
\end{array}$ & & & \\
\hline
\end{tabular}

Tabela 12 - Rankings dos Riscos Mais Relevantes (Profissionais de TI)

\begin{tabular}{|c|c|c|c|c|c|c|c|c|c|c|c|c|}
\hline \multirow{2}{*}{ Painelistas } & \multicolumn{12}{|c|}{ Riscos } \\
\hline & R1 & R3 & R4 & R5 & R6 & R7 & R8 & R9 & R11 & R12 & R14 & R18 \\
\hline D & 8 & 2 & 1 & 7 & 6 & 9 & 10 & 3 & 4 & 11 & 5 & 12 \\
\hline E & 1 & 12 & 9 & 11 & 4 & 2 & 8 & 7 & 10 & 3 & 5 & 6 \\
\hline $\mathrm{F}$ & 3 & 8 & 4 & 7 & 11 & 9 & 12 & 5 & 6 & 2 & 1 & 10 \\
\hline G & 3 & 8 & 5 & 6 & 11 & 10 & 12 & 4 & 7 & 2 & 1 & 9 \\
\hline $\mathrm{H}$ & 1 & 3 & 2 & 5 & 4 & 6 & 10 & 7 & 8 & 11 & 9 & 12 \\
\hline 1 & 4 & 8 & 3 & 7 & 11 & 10 & 12 & 5 & 6 & 2 & 1 & 9 \\
\hline J & 11 & 9 & 8 & 10 & 12 & 7 & 6 & 5 & 4 & 3 & 2 & 1 \\
\hline $\mathrm{K}$ & 3 & 7 & 4 & 8 & 11 & 10 & 12 & 5 & 6 & 1 & 2 & 9 \\
\hline$R=\sum$ ranks & 34,0 & 57,0 & 36,0 & 61,0 & 70,0 & 63,0 & 82,0 & 41,0 & 51,0 & 35,0 & 26,0 & 68,0 \\
\hline$X=R-\bar{x}$ & $-18,0$ & 5,0 & $-16,0$ & 9,0 & 18,0 & 11,0 & 30,0 & $-11,0$ & $-1,0$ & $-17,0$ & $-26,0$ & 16,0 \\
\hline$Y=X^{\wedge} 2$ & 324,00 & 25,00 & 256,00 & 81,00 & 324,00 & 121,00 & 900,00 & 121,00 & 1,00 & 289,00 & 676,00 & 256,00 \\
\hline \multirow[t]{3}{*}{ Posição } & 2 & 7 & 4 & 8 & 11 & 9 & 12 & 5 & 6 & 3 & 1 & 10 \\
\hline & & & & $\mathrm{n}=$ & 12 & $\overline{\mathbf{x}}=$ & 52,0 & $\mathbf{W}=$ & 0,369 & & & \\
\hline & & & & $\mathbf{m}=$ & 8 & $S=$ & 3374,0 & $\times 2=$ & 32,442 & & & \\
\hline
\end{tabular}

A análise destas duas últimas tabelas mostra que, no caso dos riscos, o ranking obtido para os acadêmicos é relativamente diferente do geral, com apenas uma coincidência de posições (rank do risco R8), porém nove posições próximas e duas discrepâncias significativas (ranks 3 e 7 para o risco R5 e ranks 9 e 5 para o risco R9). Por seu turno, o ranking dos profissionais 
de TI é bastante semelhante ao geral, com seis coincidências de posições (ranks dos riscos R4, R6, R8, R9, R11 e R14) e as outras seis posições próximas, sem nenhuma discrepância mais significativa.

Em ambos os casos, há um grau moderado de concordância de opiniões acerca dos riscos mais relevantes, adotadas as faixas sugeridas por Schmidt (op. cit.), pois o coeficiente de concordância é de 0,302 para os acadêmicos e 0,369 para os profissionais de TI. O teste de $\chi^{2}$ mostra que $\mathrm{W}$ tem significância em nível $p=0,0005$, para os profissionais, mas não tem significância para os acadêmicos $(p>>0,1)$. Esta situação, muito provavelmente, decorre do fato de a quantidade de acadêmicos participantes ser muito pequena e ter havido discordâncias significativas quanto à relevância de alguns riscos (é o caso de R4, R14 e R18), o que acabou pesando na consolidação. De todo modo, este aspecto não invalida o ranking geral consolidado, pois esta análise segmentada entre acadêmicos e profissionais de TI é apenas complementar, sendo válida, de fato, a análise para o grupo de painelistas como um todo.

\subsubsection{Respostas Relativas às Barreiras}

Cada painelista foi solicitado a rever sua ordenação relativa às barreiras, uma vez conhecida a opinião coletiva do grupo. Como se tratou de uma revisão opcional, apenas alguns optaram por promover modificações no ranking indicado de início. A Tabela 13 apresenta como ficaram, depois de consideradas as modificações, os novos rankings individuais e o coletivo.

Tabela 13 - Rankings das Barreiras Mais Relevantes (Após Revisão)

\begin{tabular}{|c|c|c|c|c|c|c|c|c|c|c|}
\hline \multirow{2}{*}{ Painelistas } & \multicolumn{10}{|c|}{ Barreiras } \\
\hline & B1 & B2 & B3 & B5 & B6 & B9 & B10 & B11 & B15 & B16 \\
\hline A & 1 & 2 & 8 & 5 & 6 & 4 & 7 & 9 & 10 & 3 \\
\hline$B$ & 2 & 3 & 5 & 6 & 7 & 8 & 9 & 4 & 10 & 1 \\
\hline C & 8 & 7 & 4 & 9 & 2 & 6 & 1 & 3 & 5 & 10 \\
\hline$D$ & 8 & 9 & 10 & 7 & 6 & 5 & 4 & 3 & 2 & 1 \\
\hline E & 2 & 3 & 10 & 4 & 7 & 6 & 8 & 5 & 9 & 1 \\
\hline$F$ & 4 & 2 & 9 & 3 & 8 & 6 & 7 & 5 & 10 & 1 \\
\hline G & 5 & 4 & 7 & 8 & 10 & 6 & 1 & 2 & 9 & 3 \\
\hline $\mathrm{H}$ & 9 & 3 & 4 & 5 & 7 & 6 & 8 & 10 & 1 & 2 \\
\hline 1 & 3 & 2 & 9 & 4 & 7 & 6 & 8 & 5 & 10 & 1 \\
\hline J & 3 & 2 & 9 & 4 & 8 & 5 & 7 & 6 & 10 & 1 \\
\hline $\mathrm{K}$ & 3 & 2 & 9 & 4 & 7 & 6 & 8 & 5 & 10 & 1 \\
\hline $\mathrm{R}=\sum$ ranks & 48 & 39 & 84 & 59 & 75 & 64 & 68 & 57 & 86 & 25 \\
\hline$X=R-\bar{X}$ & $-12,5$ & $-21,5$ & 23,5 & $-1,5$ & 14,5 & 3,5 & 7,5 & $-3,5$ & 25,5 & $-35,5$ \\
\hline$Y=X^{\wedge} 2$ & 156,25 & 462,25 & 552,25 & 2,25 & 210,25 & 12,25 & 56,25 & 12,25 & 650,25 & 1260,3 \\
\hline \multirow[t]{3}{*}{ Posição } & 3 & 2 & 9 & 5 & 8 & 6 & 7 & 4 & 10 & 1 \\
\hline & & & $n=$ & 10 & $\overline{\mathbf{x}}=$ & 60,5 & $\mathbf{W}=$ & 0,338 & & \\
\hline & & & $m=$ & 11 & $S=$ & 3374,5 & $x^{2}=$ & 33,466 & & \\
\hline
\end{tabular}


$\mathrm{O}$ coeficiente de concordância $\mathrm{W}$ passou a valer a 0,338 , significando que o ranking consolidado, adotadas as faixas sugeridas por Schmidt (op. cit.), passou a expressar a existência de um grau de concordância moderado entre os painelistas. $\mathrm{O}$ teste de $\chi^{2}$ mostrou significância em nível $p=0,0001$ para W. Dada a importante variação para maior verificada no coeficiente de concordância, entendeu-se que, para este tema, o painel poderia ser encerrado, assumindo-se o ranking consolidado obtido neste ciclo como sendo o final.

Desdobrando-se aqui também em dois subconjuntos as respostas relativas ao ordenamento das barreiras, têm-se em separado novos rankings consolidados dos acadêmicos e dos profissionais de TI, os quais estão apresentados nas Tabelas 14 e 15.

Tabela 14 - Rankings das Barreiras Mais Relevantes (Acadêmicos Após Revisão)

\begin{tabular}{|c|c|c|c|c|c|c|c|c|c|c|}
\hline \multirow{2}{*}{ Painelistas } & \multicolumn{10}{|c|}{ Barreiras } \\
\hline & B1 & B2 & B3 & B5 & B6 & B9 & B10 & B11 & B15 & B16 \\
\hline A & 1 & 2 & 8 & 5 & 6 & 4 & 7 & 9 & 10 & 3 \\
\hline B & 2 & 3 & 5 & 6 & 7 & 8 & 9 & 4 & 10 & 1 \\
\hline C & 8 & 7 & 4 & 9 & 2 & 6 & 1 & 3 & 5 & 10 \\
\hline$R=\sum$ ranks & 11 & 12 & 17 & 20 & 15 & 18 & 17 & 16 & 25 & 14 \\
\hline$X=R-\bar{x}$ & $-5,5$ & $-4,5$ & 0,5 & 3,5 & $-1,5$ & 1,5 & 0,5 & $-0,5$ & 8,5 & $-2,5$ \\
\hline$Y=X^{\wedge} 2$ & 30,25 & 20,25 & 0,25 & 12,25 & 2,25 & 2,25 & 0,25 & 0,25 & 72,25 & 6,25 \\
\hline \multirow[t]{3}{*}{ Posição } & 1 & 2 & 6 & 9 & 4 & 8 & 6 & 5 & 10 & 3 \\
\hline & & & $\mathrm{n}=$ & 10 & $\overline{\mathbf{x}}=$ & 16,5 & $\mathbf{w}=$ & 0,197 & & \\
\hline & & & $m=$ & 3 & $S=$ & 146,5 & $x 2=$ & 5,327 & & \\
\hline
\end{tabular}

Tabela 15 - Rankings das Barreiras Mais Relevantes (Profissionais de TI Após Revisão)

\begin{tabular}{|c|c|c|c|c|c|c|c|c|c|c|}
\hline \multirow{2}{*}{ Painelistas } & \multicolumn{10}{|c|}{ Barreiras } \\
\hline & B1 & B2 & B3 & B5 & B6 & B9 & B10 & B11 & B15 & B16 \\
\hline D & 8 & 9 & 10 & 7 & 6 & 5 & 4 & 3 & 2 & 1 \\
\hline$E$ & 2 & 3 & 10 & 4 & 7 & 6 & 8 & 5 & 9 & 1 \\
\hline$F$ & 4 & 2 & 9 & 3 & 8 & 6 & 7 & 5 & 10 & 1 \\
\hline G & 5 & 4 & 7 & 8 & 10 & 6 & 1 & 2 & 9 & 3 \\
\hline $\mathrm{H}$ & 9 & 3 & 4 & 5 & 7 & 6 & 8 & 10 & 1 & 2 \\
\hline I & 3 & 2 & 9 & 4 & 7 & 6 & 8 & 5 & 10 & 1 \\
\hline J & 3 & 2 & 9 & 4 & 8 & 5 & 7 & 6 & 10 & 1 \\
\hline $\mathrm{K}$ & 3 & 2 & 9 & 4 & 7 & 6 & 8 & 5 & 10 & 1 \\
\hline $\mathrm{R}=\sum$ ranks & 37 & 27 & 67 & 39 & 60 & 46 & 51 & 41 & 61 & 11 \\
\hline$X=R-\bar{X}$ & $-7,0$ & $-17,0$ & 23,0 & $-5,0$ & 16,0 & 2,0 & 7,0 & $-3,0$ & 17,0 & $-33,0$ \\
\hline$Y=X^{\wedge} 2$ & 49 & 289 & 529 & 25 & 256 & 4 & 49 & 9 & 289 & 1089 \\
\hline Posição & 3 & 2 & 10 & 4 & 8 & 6 & 7 & 5 & 9 & 1 \\
\hline & & & $\begin{array}{r}n= \\
m=\end{array}$ & $\begin{array}{c}10 \\
8\end{array}$ & $\begin{array}{l}\overline{\mathbf{x}}= \\
\mathbf{S}=\end{array}$ & $\begin{array}{r}44,0 \\
2588,0\end{array}$ & $\begin{array}{l}w= \\
x 2=\end{array}$ & $\begin{array}{r}0,490 \\
35,291\end{array}$ & & \\
\hline
\end{tabular}

Após a revisão, o novo ranking dos acadêmicos é relativamente diferente do geral, com apenas duas coincidências de posições (ranks das barreiras B2 e B15), duas posições 
próximas (ranks das barreiras B10 e B11) e três discrepâncias significativas (ranks 6 e 9 para a barreira B3, ranks 9 e 5 para a barreira B5 e ranks 4 e 8 para a barreira B6). Por seu turno, o novo ranking dos profissionais de TI é altamente semelhante ao geral, com seis coincidências de posições (ranks das barreiras B1, B2, B6, B9, B10 e B16) e as outras quatro posições próximas (ranks das barreiras B3, B5, B11 e B15).

Houve uma inversão nos graus de concordância, adotadas as faixas sugeridas por Schmidt (op. cit.). Os acadêmicos, entre os quais havia uma alta concordância, tiveram seu coeficiente reduzido para 0,197 , ao passo que os profissionais de TI, cuja concordância apresentava um grau baixo, tiveram seu coeficiente aumentado para 0,490, o que agora representa um grau moderado. $\mathrm{O}$ teste de $\chi^{2}$ mostra que $\mathrm{W}$ tem significância em nível $p=0,0001$, para os profissionais de TI, mas não tem significância para os acadêmicos. A explicação para esta situação verificada com os acadêmicos é a mesma já apresentada acima para o caso dos riscos.

\subsubsection{Respostas Relativas aos Benefícios}

Do mesmo modo, cada painelista foi solicitado a rever sua ordenação relativa aos benefícios, uma vez conhecida a opinião coletiva do grupo. Como se tratou, uma vez mais, de uma revisão opcional, também apenas alguns optaram por promover modificações no ranking indicado de início. A Tabela 16 apresenta como ficaram, depois de consideradas as modificações, os novos rankings individuais e o coletivo.

Tabela 16 - Rankings dos Benefícios Mais Relevantes (Após Revisão)

\begin{tabular}{|c|c|c|c|c|c|c|c|c|c|c|}
\hline \multirow{2}{*}{ Painelistas } & \multicolumn{10}{|c|}{ Benefícios } \\
\hline & V1 & V2 & V3 & V5 & V6 & V7 & V8 & V11 & V13 & V14 \\
\hline$A$ & 2 & 3 & 9 & 4 & 5 & 7 & 8 & 10 & 6 & 1 \\
\hline B & 3 & 2 & 4 & 5 & 1 & 6 & 7 & 8 & 10 & 9 \\
\hline C & 9 & 1 & 4 & 5 & 7 & 6 & 8 & 10 & 3 & 2 \\
\hline D & 4 & 3 & 2 & 9 & 8 & 10 & 7 & 1 & 6 & 5 \\
\hline$E$ & 2 & 5 & 6 & 3 & 1 & 10 & 9 & 8 & 7 & 4 \\
\hline $\mathrm{F}$ & 1 & 3 & 5 & 4 & 2 & 10 & 8 & 9 & 6 & 7 \\
\hline G & 1 & 7 & 5 & 4 & 2 & 3 & 6 & 10 & 8 & 9 \\
\hline $\mathrm{H}$ & 10 & 1 & 2 & 7 & 5 & 4 & 6 & 8 & 3 & 9 \\
\hline I & 1 & 2 & 4 & 5 & 3 & 8 & 9 & 10 & 6 & 7 \\
\hline$J$ & 2 & 4 & 5 & 3 & 1 & 10 & 8 & 7 & 6 & 9 \\
\hline $\mathrm{K}$ & 5 & 2 & 3 & 4 & 1 & 6 & 7 & 8 & 9 & 10 \\
\hline$R=\sum$ ranks & 40 & 33 & 49 & 53 & 36 & 80 & 83 & 89 & 70 & 72 \\
\hline$X=R-\bar{x}$ & $-20,5$ & $-27,5$ & $-11,5$ & $-7,5$ & $-24,5$ & 19,5 & 22,5 & 28,5 & 9,5 & 11,5 \\
\hline$Y=X^{\wedge} 2$ & 420,25 & 756,25 & 132,25 & 56,25 & 600,25 & 380,25 & 506,25 & 812,25 & 90,25 & 132,25 \\
\hline \multirow[t]{2}{*}{ Posição } & 3 & 1 & 4 & 5 & 2 & 8 & 9 & 10 & 6 & 7 \\
\hline & & & $\begin{array}{r}n= \\
m=\end{array}$ & $\begin{array}{l}10 \\
11 \\
\end{array}$ & $\begin{array}{l}\overline{\mathbf{x}}= \\
\mathrm{S}=\end{array}$ & $\begin{array}{r}60,5 \\
3886,5 \\
\end{array}$ & $\begin{array}{l}w= \\
\times 2=\end{array}$ & $\begin{array}{r}0,389 \\
38,544 \\
\end{array}$ & & \\
\hline
\end{tabular}


$\mathrm{O}$ coeficiente de concordância $\mathrm{W}$ passou a valer a 0,389 , significando que o ranking consolidado, adotadas as faixas sugeridas por Schmidt (op. cit.), passou a expressar a existência de um grau de concordância moderado entre os painelistas. $\mathrm{O}$ teste de $\chi^{2}$ mostrou significância em nível $p=0,00001$ para W. Dada a importante variação para maior verificada no coeficiente de concordância, entendeu-se que, igualmente para este tema, o painel poderia ser encerrado, assumindo-se o ranking consolidado obtido neste ciclo como sendo o final.

Uma vez mais, foram desdobradas em dois subconjuntos as respostas relativas ao ordenamento dos benefícios, obtendo-se em separado novos rankings consolidados dos acadêmicos e dos profissionais de TI, os quais estão apresentados nas Tabelas 17 e 18 .

Tabela 17 - Rankings dos Benefícios Mais Relevantes (Acadêmicos Após Revisão)

\begin{tabular}{|c|c|c|c|c|c|c|c|c|c|c|}
\hline \multirow{2}{*}{ Painelistas } & \multicolumn{10}{|c|}{ Benefícios } \\
\hline & V1 & V2 & V3 & V5 & V6 & V7 & V8 & V11 & V13 & V14 \\
\hline$A$ & 2 & 3 & 9 & 4 & 5 & 7 & 8 & 10 & 6 & 1 \\
\hline B & 3 & 2 & 4 & 5 & 1 & 6 & 7 & 8 & 10 & 9 \\
\hline C & 9 & 1 & 4 & 5 & 7 & 6 & 8 & 10 & 3 & 2 \\
\hline$R=\sum$ ranks & 14 & 6 & 17 & 14 & 13 & 19 & 23 & 28 & 19 & 12 \\
\hline$X=R-\bar{x}$ & $-2,5$ & $-10,5$ & 0,5 & $-2,5$ & $-3,5$ & 2,5 & 6,5 & 11,5 & 2,5 & $-4,5$ \\
\hline$Y=X^{\wedge} 2$ & 6,25 & 110,25 & 0,25 & 6,25 & 12,25 & 6,25 & 42,25 & 132,25 & 6,25 & 20,25 \\
\hline Posição & 4 & 1 & 5 & 4 & 3 & 7 & 9 & 10 & 7 & 2 \\
\hline & & & $\begin{array}{r}n= \\
m=\end{array}$ & $\begin{array}{c}10 \\
3 \\
\end{array}$ & $\begin{array}{l}\overline{\mathbf{x}}= \\
S=\end{array}$ & $\begin{array}{r}16,5 \\
342,5\end{array}$ & $\begin{array}{l}w= \\
x^{2}=\end{array}$ & \begin{tabular}{r|}
0,461 \\
12,455 \\
\end{tabular} & & \\
\hline
\end{tabular}

Tabela 18 - Rankings dos Benefícios Mais Relevantes (Profissionais de TI Após Revisão)

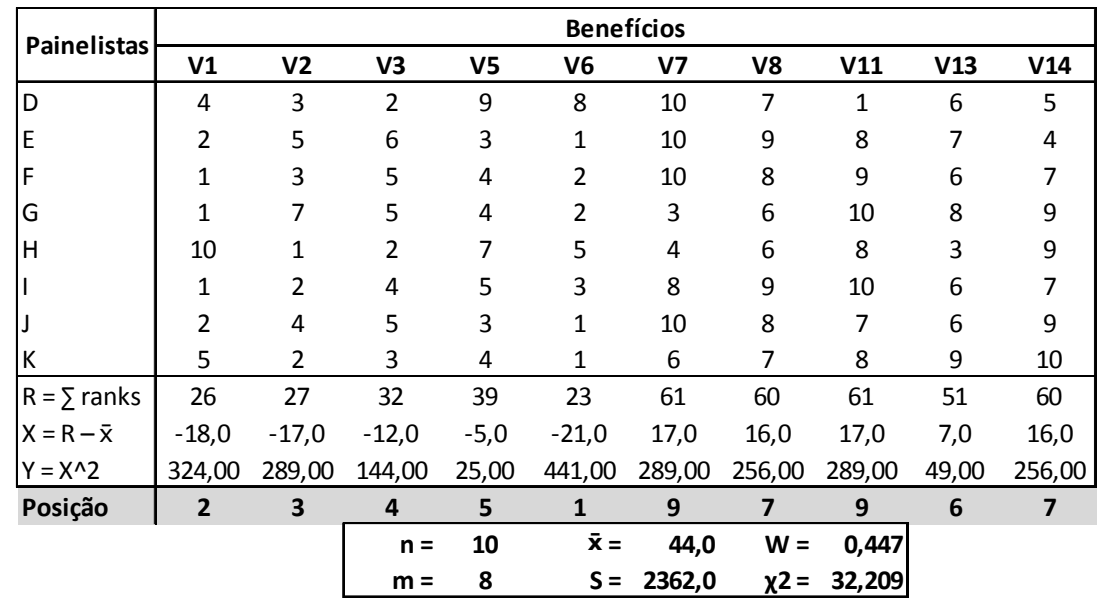

Após a revisão, o ranking obtido para os acadêmicos é pouco diferente do geral, com três coincidências de posições (ranks dos benefícios V2, V8 e V11), seis posições próximas e 
apenas uma discrepância significativa (ranks 2 para 7, para o benefício V14). Já o ranking dos profissionais de TI é bastante semelhante ao geral, com quatro coincidências de posições (ranks dos benefícios V4, V5, V13 e V14) e as outras oito posições próximas, sem nenhuma discrepância mais significativa.

Tanto para os acadêmicos quanto para os profissionais de TI, os coeficientes de concordância elevaram-se a um patamar ainda acima do ranking geral, indo, respectivamente, a 0,461 e 0,447, representando, em ambos os casos, um grau de concordância moderado, adotadas as faixas sugeridas por Schmidt (op. cit.). O teste de $\chi^{2}$ mostra que $\mathrm{W}$ tem significância em nível $p=0,0001$, para os profissionais, mas não tem significância para os acadêmicos. A explicação para esta situação verificada com os acadêmicos é a mesma já apresentada acima para os casos dos riscos e das barreiras.

\subsection{Supressão do Ciclo 5 do Painel}

O Ciclo 5 teria como foco o aprimoramento do grau de concordância entre os painelistas, relativamente aos temas que porventura ainda estivessem apresentando grau muito baixo ou baixo.

Tendo em vista que, com a realização do Ciclo 4, obteve-se um grau de concordância

moderado para os três temas (barreiras, benefícios e riscos), tornou-se desnecessário prosseguir com o painel e, consequentemente, este ciclo acabou por não ser realizado.

\subsection{Elaboração das Conclusões}

As conclusões finais acerca da visão dos painelistas relativamente aos riscos, benefícios e barreiras potenciais associados aos ambientes de computação em nuvem não privada estão apresentadas nos dois próximos capítulos deste documento. 


\section{RECOMENDAÇÕES PARA O TRATAMENTO DOS RISCOS INERENTES À COMPUTAÇÃO EM NUVEM}

Até este momento do estudo, os objetivos secundários estabelecidos haviam sido alcançados e representados pelo conteúdo dos Capítulos 2 e 4 deste documento. A título de recordação, estes objetivos são:

- Identificar os benefícios potenciais citados em estudos acadêmicos como passíveis de ser obtidos, pelos consumidores de serviços, com a adoção da computação em nuvem;

- Identificar e apresentar, de maneira ordenada, as propostas oriundas do meio acadêmico para o tratamento, por parte dos consumidores de serviços, das questões das barreiras e dos riscos inerentes à computação em nuvem;

- Explicitar semelhanças, divergências, pontos fortes e deficiências das distintas propostas identificadas, relativamente a barreiras e benefícios;

- Explorar e verificar a pertinência e adequação dos benefícios apontados e das recomendações relativas a barreiras e riscos constantes das propostas identificadas.

De modo a poder cumprir com o objetivo principal, seria ainda necessário fazer as recomendações com vistas a auxiliar os consumidores de serviços de computação em nuvem a tratar adequadamente a questão dos riscos, ou seja, conforme estabelecido neste objetivo: identificar os riscos, compreendê-los e preparar-se para gerenciá-los, de modo tal a poder contratar serviços oferecidos em nuvens com grau aceitável de risco. E é, então, o que é feito neste capítulo, no qual são apresentadas e detalhadas as recomendações voltadas a risco.

\subsection{Riscos Inerentes à Computação em Nuvem}

O painel Delphi realizado mostrou, na visão dos painelistas participantes, quais riscos inerentes à computação em nuvem não privada, sob a ótica dos consumidores de serviços desta natureza, devem ser considerados com mais atenção. O ranking coletivo obtido ao final do painel está reproduzido no Quadro 15, o qual agrega, na coluna mais à direita, a indicação do grupo (conforme definido no Quadro 8) ao qual cada risco pode ser associado. Aos riscos 
R11, R12 e R14, que não constam do Quadro 8, foram atribuídos grupos de acordo com o mesmo critério adotado no tópico 2.2.5.

\section{Quadro 15 - Ranking de Riscos Potenciais Inerentes à Computação em Nuvem Não Privada}

\begin{tabular}{|c|c|c|c|}
\hline Posiçã & No. & Enunciado & Grupo de Riscos \\
\hline 1 & R14 & $\begin{array}{l}\text { Dificuldade para integrar: dificuldade significativa ou, no limite, } \\
\text { impossibilidade de integrar diferentes aplicativos de um mesmo ou de } \\
\text { distintos fornecedores }\end{array}$ & Operacionais \\
\hline 2 & R12 & $\begin{array}{l}\text { Imaturidade do modelo: baixa maturidade do modelo de prestação de } \\
\text { serviços em nuvem por ser muito recente, podendo gerar exposição } \\
\text { indevida para os gestores de TI dos clientes }\end{array}$ & De Negócio \\
\hline 3 & R1 & $\begin{array}{l}\text { Falta de privacidade: baixo grau de confidencialidade e deficiências de } \\
\text { isolamento no ambiente da nuvem, possibilitando acessos indevidos } \\
\text { e/ou adulteração de dados e/ou aplicativos de consumidores }\end{array}$ & Operacionais \\
\hline 4 & $\mathrm{R} 4$ & $\begin{array}{l}\text { Baixo desempenho: desempenho insatisfatório dos serviços contratados } \\
\text { (devido a picos de demanda, balanceamento inadequado, } \\
\text { subdimensionamento dos recursos, alta latência de rede e outros fatores } \\
\text { assemelhados), levando ao descumprimento dos SLA's }\end{array}$ & Operacionais \\
\hline 5 & R9 & $\begin{array}{l}\text { Baixa interoperabilidade: dificuldade significativa ou, no limite, } \\
\text { impossibilidade de intercambiar dados e/ou aplicativos entre distintos } \\
\text { provedores }\end{array}$ & Operacionais \\
\hline 6 & R11 & $\begin{array}{l}\text { Incapacidade: baixa capacidade e/ou inexperiência do provedor para } \\
\text { prestar serviços da natureza dos ofertados em ambientes de computação } \\
\text { em nuvem }\end{array}$ & Estruturais \\
\hline 7 & R5 & $\begin{array}{l}\text { Dificuldade para escalar: demora excessiva ou dificuldades do } \\
\text { provedor para provisionar e/ou liberar recursos da nuvem }\end{array}$ & Operacionais \\
\hline 8 & R3 & $\begin{array}{l}\text { Suporte inadequado: falhas de natureza diversa no serviço de suporte, } \\
\text { tais como pessoal mal preparado, gargalos no atendimento, } \\
\text { indisponibilidade do serviço etc. }\end{array}$ & Operacionais \\
\hline 9 & R18 & $\begin{array}{l}\text { Não conformidade: não atendimento a aspectos ditados pela legislação } \\
\text { ou disciplinados por padrões de larga aceitação na indústria }\end{array}$ & Estruturais \\
\hline 10 & R7 & $\begin{array}{l}\text { Não-continuidade: interrupção definitiva da prestação dos serviços pelo } \\
\text { provedor }\end{array}$ & De Negócio \\
\hline 11 & R6 & $\begin{array}{l}\text { Indisponibilidade: interrupção temporária dos serviços em decorrência } \\
\text { de problemas técnicos ou de ordem diversa de parte do provedor }\end{array}$ & De Negócio \\
\hline 12 & R8 & $\begin{array}{l}\text { Aprisionamento: dificuldade significativa ou, no limite, } \\
\text { impossibilidade de trocar de provedor, devido a particularidades do } \\
\text { ambiente e/ou aspectos contratuais }\end{array}$ & Estruturais \\
\hline
\end{tabular}

A análise do Quadro 15 mostra que, no ranking coletivo, há uma prevalência, em termos de atenção requerida, dos riscos operacionais sobre os dos demais grupos. Este aspecto fica demonstrado pelo fato de, entre os riscos que ocupam as cinco primeiras posições do ranking, quatro deles serem operacionais. 
O risco alçado à condição de mais relevante diz respeito à dificuldade para integrar diferentes aplicativos de um mesmo ou de distintos fornecedores, dando a entender que os painelistas consideram viável contratar serviços de mais de um provedor, buscando as soluções que se mostrarem mais convenientes. O risco de se defrontar com baixa interoperabilidade, que ocupa a quinta posição no ranking, reforça este ponto de vista.

O segundo risco considerado mais relevante refere-se à imaturidade do modelo de prestação de serviços em nuvem e é o único risco não operacional entre os cinco primeiros do ranking. Este risco reflete a preocupação dos gestores de TI quanto a se expor indevidamente perante suas organizações, caso suas escolhas relativas a provedores e serviços contratados apresentem problemas que venham a impactar os negócios. É o visceral debate entre escolher ser um pioneiro ou aguardar a consolidação das novas tecnologias para só depois aderir a elas.

A terceira, a quarta e a quinta posições do ranking estão ocupadas por riscos operacionais: falta de privacidade, baixo desempenho e baixa interoperabilidade. São questões técnicas da maior importância e sua colocação no topo do ranking reflete as preocupações dos painelistas para com a violação de dados e aplicativos, para com o desempenho insatisfatório e o consequente não cumprimento dos acordos de nível de serviço contemplados nos contratos e ainda para com restrições ao intercâmbio de dados e aplicativos entre distintos provedores.

Num bloco intermediário, ocupando da sexta à nona posições, estão colocados riscos estruturais e operacionais que acabaram por ser considerados pelos painelistas como demandadores de atenção apenas mediana. Neste conjunto, estão as questões da incapacidade do provedor para prestar serviços da natureza dos da computação em nuvem, da dificuldade apresentada pelo provedor para viabilizar o provisionamento e a liberação dinâmicos de recursos, da inadequação do suporte oferecido pelo provedor e do não atendimento a aspectos ditados pela legislação ou disciplinados por padrões de larga aceitação na indústria.

Chama a atenção, por fim, o fato de os riscos de não-continuidade e indisponibilidade ocuparem posições menos relevantes no ranking consolidado, o que, de certa forma, não retrata o senso comum, pois estes deveriam ser pontos de redobrada atenção, pelo potencial impacto negativo que podem gerar nos negócios. Talvez esta baixa importância se deva ao fato de os painelistas considerarem que os provedores aos quais já estão vinculados ou que 
estão sendo objeto de avaliação demonstram efetiva solidez empresarial, comprovada capacitação técnica e clara disposição de permanecer no negócio da computação em nuvem.

\subsection{Recomendações para Tratamento dos Riscos}

Para atender na plenitude ao objetivo principal estabelecido para este estudo, estas recomendações devem possibilitar: (a) que os riscos inerentes à computação em nuvem sejam identificados e compreendidos e (b) que os consumidores de serviços oferecidos em nuvens possam se preparar para gerenciar estes riscos, com vistas a mantê-los em patamares aceitáveis, que propiciem a segurança necessária para a realização de contratações.

Este estudo não contempla, entre seus objetivos, a recomendação ou a proposição de um roteiro ou sistemática para gestão dos riscos inerentes à computação em nuvem, mas apenas visa focar nas já mencionadas recomendações que possam contribuir para o tratamento destes riscos. Entretanto, para tornar didática a apresentação das recomendações, é necessário referenciar um esquema para gestão de riscos, o que está sendo feito, sem, todavia, a conotação de recomendá-lo como um preferido.

Isto posto, considere-se então como referência o esquema para gestão de riscos já apresentado na Figura 10 e proposto por Westerman e Hunter (op. cit.), do qual interessam, mais especificamente, apenas duas das suas cinco etapas, dado que as demais ocupam-se de temas não diretamente associados com o foco desta análise. Para sinalizar as duas etapas relevantes, este esquema está reapresentado na Figura 15, com destaque para as mesmas, que são: (a) identificar e avaliar riscos e (b) priorizar riscos e atribuir responsabilidades.

Figura 15 - Etapas Destacadas da Gestão dos Riscos da TI

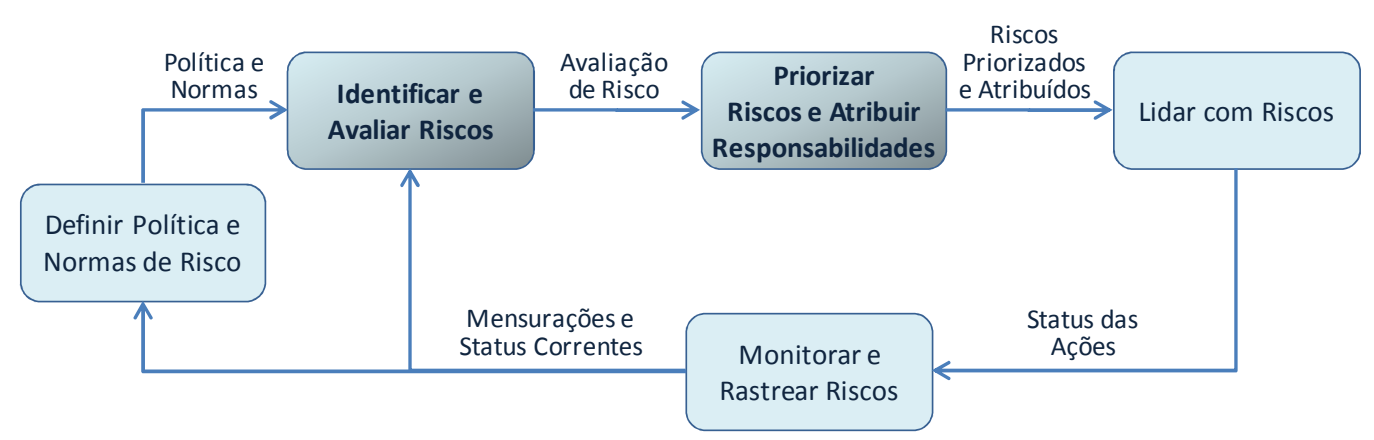

FONTE: Adaptado de Westerman e Hunter; 2007; p. 117. 
Na realidade, nem são estas duas etapas na íntegra que têm relevância para introduzir as recomendações. Da etapa de identificação e avaliação dos riscos, o foco recai somente na identificação e, da etapa de priorização e atribuição de responsabilidades, na priorização apenas. Os passos de avaliação e atribuição de responsabilidades já pressupõem a existência de uma sistemática de gestão de riscos, o que remete às considerações feitas dois parágrafos acima, qual seja, o "como" estes passos devem ser executados não está no escopo deste estudo.

Portanto, as recomendações aqui colocadas para o tratamento dos riscos aplicam-se às partes acima explicitadas das duas etapas destacadas na Figura 15. Evidentemente, estas recomendações só têm validade se considerada a existência de um processo formal e sistemático de avaliação de riscos, sem o que se torna inviável colocá-las em prática.

Em detalhe, pode-se afirmar que se tem:

- No que se refere à identificação dos riscos:

- O primeiro passo para a identificação de riscos efetivos é o conhecimento acerca de a quais riscos potenciais se está exposto;

- Neste caso, deve-se assumir que o elenco de riscos potenciais está definido pelo resultado obtido com o painel Delphi;

- Portanto, tomando por base a opinião coletiva do grupo de especialistas envolvidos no painel e dado que estes especialistas tiveram ainda a oportunidade de conhecer e revisar a opinião de diversos acadêmicos que anteriormente se ocuparam deste tema, é lícito afirmar que os riscos relacionados no Quadro 15 são efetivamente os que se deve levar em conta ao avaliar a perspectiva de contratar serviços de computação em nuvem.

- No que se refere à priorização dos riscos:

- Uma vez identificados os riscos potenciais, pode-se priorizá-los, sob a ótica do maior ou menor impacto potencial que cada um apresenta;

- Neste caso, uma vez mais o resultado do painel Delphi contribui, pois já trás no seu bojo uma sugestão para priorização dos riscos, representada pelo ranking coletivo obtido em decorrência do trabalho de ordenação realizado pelos especialistas envolvidos.

Traduzindo estas colocações em termos de recomendações, tem-se: 


\section{Recomendação 1: Quanto à Avaliação dos Riscos}

Ao avaliar a perspectiva de firmar ou rever contratos de serviços de computação de nuvem, considere a avaliação dos riscos como uma atividade mandatória no processo.

\section{Justificativa:}

A ainda pouca experiência dos provedores no fornecimento de serviços desta natureza é um fator determinante para que a contratação ou revisão de contratos de serviços desta natureza seja precedida por uma ampla avaliação de riscos, atividade que deve ser mantida ao longo de toda a vigência dos contratos.

\section{Recomendação 2: Quanto ao Elenco de Riscos}

Ao avaliar a perspectiva de firmar ou rever contratos de serviços de computação de nuvem, minimize o esforço a ser aplicado na identificação dos riscos potenciais aos quais esses serviços poderão estar expostos, utilizando como ponto de partida o seguinte elenco de riscos:

1. Dificuldade para integrar: dificuldade significativa ou, no limite, impossibilidade de integrar diferentes aplicativos de um mesmo ou de distintos fornecedores;

2. Imaturidade do modelo: baixa maturidade do modelo de prestação de serviços em nuvem por ser muito recente, podendo gerar exposição indevida para os gestores de TI dos clientes;

3. Falta de privacidade: baixo grau de confidencialidade e deficiências de isolamento no ambiente da nuvem, possibilitando acessos indevidos e/ou adulteração de dados e/ou aplicativos de consumidores;

4. Baixo desempenho: desempenho insatisfatório dos serviços contratados (devido a picos de demanda, balanceamento inadequado, subdimensionamento dos recursos, alta latência de rede e outros fatores assemelhados), levando ao descumprimento dos SLA's;

5. Baixa interoperabilidade: dificuldade significativa ou, no limite, impossibilidade de intercambiar dados e/ou aplicativos entre distintos provedores;

6. Incapacidade: baixa capacidade e/ou inexperiência do provedor para prestar serviços da natureza dos ofertados em ambientes de computação em nuvem;

7. Dificuldade para escalar: demora excessiva ou dificuldades do provedor para provisionar e/ou liberar recursos da nuvem;

8. Suporte inadequado: falhas de natureza diversa no serviço de suporte, tais como pessoal mal preparado, gargalos no atendimento, indisponibilidade do serviço etc.;

9. Não conformidade: não atendimento a aspectos ditados pela legislação ou disciplinados por padrões de larga aceitação na indústria;

10. Não-continuidade: interrupção definitiva da prestação dos serviços pelo provedor;

11. Indisponibilidade: interrupção temporária dos serviços em decorrência de problemas técnicos ou de ordem diversa de parte do provedor;

12. Aprisionamento: dificuldade significativa ou, no limite, impossibilidade de trocar de provedor, devido a particularidades do ambiente e/ou aspectos contratuais. 


\section{Recomendação 2: Quanto ao Elenco de Riscos (cont.)}

\section{Justificativa:}

Este elenco de riscos retrata a opinião coletiva de um grupo de especialistas em computação em nuvem, os quais, ao longo do trabalho de análise que realizaram, além de contribuir com sua experiência pessoal, tiveram ainda a oportunidade de conhecer e revisar a opinião de diversos acadêmicos que anteriormente se ocuparam deste tema.

\section{Recomendação 3: Quanto ao Impacto Potencial dos Riscos}

Ao avaliar a perspectiva de firmar ou rever contratos de serviços de computação de nuvem, minimize o esforço a ser aplicado na identificação do impacto potencial dos riscos sobre os serviços a serem contratados, utilizando como ponto de partida exatamente a sequência na qual os riscos elencados estão apresentados na Recomendação 2, sequência esta que reflete o poder relativo de impacto existente entre eles.

\section{Justificativa:}

A sequência na qual os riscos estão apresentados retrata a opinião coletiva de um grupo de especialistas em computação em nuvem, os quais, ao longo do trabalho de análise que realizaram, culminaram com a proposição de um ranking para esses riscos, levando em conta sua importância ou poder relativo de impacto sobre os serviços oferecidos em ambientes de computação em nuvem. 


\section{CONCLUSÕES E CONSIDERAÇÕES FINAIS}

Cumpridos todos os objetivos a que este estudo se propôs, este capítulo trata das conclusões e das considerações finais, explorando os aspectos mais relevantes relacionados às barreiras, benefícios e riscos inerentes aos ambientes de computação em nuvem.

\subsection{Conclusões Acerca das Barreiras}

Conforme destacado no tópico 4.4, o painel Delphi realizado contribuiu com a indicação, pelos especialistas envolvidos, de 16 barreiras potenciais que podem inibir a adoção da computação em nuvem. Por outro lado, a literatura acadêmica pouco tem explorado a questão das barreiras e a pesquisa bibliográfica realizada neste estudo encontrou apenas duas referências a este tema, menções feitas por Miller (op. cit.) e por Marks e Lozano (op. cit.) e exploradas no tópico 2.1.6 deste documento; estas fontes forneceram nove outras barreiras (as quais estão relacionadas no Quadro 5), porém nenhuma, em essência, acrescentou novidades a este tema.

Portanto, como já explorado no tópico 4.5, foram então submetidas 16 barreiras à análise dos painelistas, com vistas a obter o elenco das dez mais relevantes e seu subsequente ordenamento em ordem de importância. O resultado final deste trabalho, que se desenvolveu ao longo dos três últimos ciclos do painel, está apresentado no Quadro 16.

\section{Quadro 16 - Ranking de Barreiras Potenciais à Adoção da Computação em Nuvem Não Privada}

\begin{tabular}{crl}
\hline Posição No. & Enunciado \\
\hline \hline 1 & B16 & $\begin{array}{l}\text { Dúvidas quanto à viabilidade da terceirização de determinados serviços, em função de } \\
\text { criticidade dos negócios e necessidade de controle }\end{array}$ \\
\hline 2 & B2 & $\begin{array}{l}\text { Riscos inerentes ao modelo de serviços, muitos dos quais ainda desconhecidos e que } \\
\text { podem não ser adequadamente esclarecidos pelo fornecedor }\end{array}$ \\
\hline 3 & B1 & $\begin{array}{l}\text { Maturidade ainda não comprovada do modelo de serviços e governança, por ser muito } \\
\text { novo }\end{array}$ \\
\hline 5 & B11 & $\begin{array}{l}\text { Dúvidas quanto à capacidade do fornecedor em negociar satisfatoriamente e atender a } \\
\text { SLA's }\end{array}$ \\
\hline 6 & B9 & Dúvidas quanto à segurança que possa vir a ser oferecida pelo fornecedor \\
\hline
\end{tabular}


Quadro 16 - Ranking de Barreiras Potenciais à Adoção da

Computação em Nuvem Não Privada (cont.)

Posição No. Enunciado

\begin{tabular}{ccl}
\hline \hline 7 & B10 & Dúvidas quanto à capacidade e agilidade do fornecedor em prover suporte \\
\hline 8 & B6 & $\begin{array}{l}\text { Dúvidas quanto à capacidade do fornecedor em garantir disponibilidade e dispor de } \\
\text { recursos para atender a contingências }\end{array}$ \\
\hline 9 & B3 & Oferta de serviços ainda limitada \\
\hline 10 & B15 & Investimentos recentes realizados pelo comprador em infra-estrutura própria \\
\hline D & B4 & Custo elevado dos serviços ofertados \\
\hline D & B7 & $\begin{array}{l}\text { Dúvidas quanto à qualidade dos recursos de infra-estrutura e rede de comunicações } \\
\text { adotados pelo fornecedor }\end{array}$ \\
\hline D & B8 & $\begin{array}{l}\text { Dúvidas quanto à capacidade do fornecedor em realizar em tempo hábil a implantação e } \\
\text { expansão dos serviços contratados }\end{array}$ \\
\hline D & B12 & $\begin{array}{l}\text { Dúvidas quanto ao tratamento a ser recebido de parte do fornecedor, face à eventual baixa } \\
\text { representatividade dos serviços contratados }\end{array}$ \\
\hline D & B13 & $\begin{array}{l}\text { Receio quanto à comunicação com um fornecedor estrangeiro, por conta de dificuldades } \\
\text { com o idioma }\end{array}$ \\
\hline D & B14 & \begin{tabular}{l} 
Falta de cultura por parte do comprador \\
\hline D - Desconsiderada no processo de indicação das mais relevantes
\end{tabular} \\
\hline \hline
\end{tabular}

Focando nesse ranking de barreiras construído com a colaboração dos painelistas, verifica-se que a barreira por eles considerada a mais importante coloca uma questão básica em pauta: o que transferir para nuvens? Aplicações críticas para o negócio podem ser transferidas ou devem ser processadas em instalações próprias?

O roteiro elaborado pela CSA (op. cit.), apresentado no tópico 2.2.6 deste documento, aborda exatamente esta questão, oferecendo um instrumental que possibilita a uma organização avaliar e definir o que ela entende como passível de ser colocado em nuvens, face aos riscos que está propensa a correr.

Analisando a sequência do ranking, é interessante notar que as barreiras que ocupam as duas posições seguintes são relacionadas, de certa forma, ao modelo de negócios da computação em nuvem, explorando o aspecto do ainda pouco tempo de maturação deste modelo, o que, sem dúvida, trás à tona questionamentos e dúvidas acerca da conveniência de aderir a ele já neste momento. 
Prosseguindo na exploração do ranking, tem-se que as cinco barreiras seguintes estão associadas a dúvidas quanto à efetiva capacidade dos provedores em atender a contento aos potenciais consumidores dos serviços por eles ofertados. É muito provável que estas dúvidas tenham sido colocadas pelos painelistas também em função do pouco tempo de atuação e da consequente pouca experiência acumulada pela maioria desses provedores, salvo algumas notórias exceções, como, por exemplo, o Google, a Microsoft e a salesforce.com.

\subsection{Conclusões Acerca dos Benefícios}

No que diz respeito aos benefícios, a literatura acadêmica é mais profícua. No tópico 2.1.5 deste documento estão citados quatro autores e um total de 17 benefícios potenciais por eles apresentados e detalhados, dentre os quais alguns bastante assemelhados e que acabaram por ser reduzidos a apenas nove distintos, que estão relacionados no Quadro 4. Os painelistas, por sua vez, conforme destacado no tópico 4.4, contribuíram com outros 12 benefícios e, do confronto entre essas duas listas, concluiu-se que vários itens tinham o mesmo significado, o que acabou por levar a uma relação final de 14 benefícios efetivamente diferentes entre si.

Portanto, como já explorado no tópico 4.5, foram então submetidos esses 14 benefícios à análise dos painelistas, com vistas a obter o elenco dos dez mais relevantes e seu subsequente ordenamento em ordem de importância. O resultado final deste trabalho, que também ocorreu ao longo dos três últimos ciclos do painel, está apresentado no Quadro 17.

\section{Quadro 17 - Ranking de Benefícios Potenciais Decorrentes da Adoção da Computação em Nuvem Não Privada}

\begin{tabular}{ccl}
\hline Posição No. & Enunciado \\
\hline \hline 1 & V2 & Propicia maior simplicidade e menor esforço para gerir os ativos alocados a TI \\
\hline 2 & V6 & Viabiliza a implantação mais rápida de novos serviços e aplicativos \\
\hline 3 & V1 & Permite concentrar o foco de TI nos negócios e em processos core \\
\hline 4 & V3 & $\begin{array}{l}\text { Reduz ou elimina a necessidade de lidar com planejamento de capacidade e outros } \\
\text { processos associados a ativos próprios }\end{array}$ \\
\hline 5 & V5 & $\begin{array}{l}\text { Demanda investimentos iniciais menores para se dispor do mesmo nível de recursos e } \\
\text { tecnologia }\end{array}$ \\
\hline 7 & V13 & $\begin{array}{l}\text { Facilita o acesso a inovações, tornando possível utilizar novos tipos de aplicativos e } \\
\text { serviços não possíveis em outras condições }\end{array}$ \\
\hline
\end{tabular}




\section{Quadro 17 - Ranking de Benefícios Potenciais Decorrentes da}

Adoção da Computação em Nuvem Não Privada (cont.)

Posição No. Enunciado

\begin{tabular}{|c|c|c|}
\hline 8 & V7 & Confere maior grau de disponibilidade aos serviços \\
\hline 9 & V8 & $\begin{array}{l}\text { Oferece escalabilidade, proporcionando flexibilidade para crescer e lidar com situações de } \\
\text { pico e sazonalidade }\end{array}$ \\
\hline 10 & V11 & $\begin{array}{l}\text { Permite substituir investimentos em ativos (CAPEX) por despesas (OPEX), gerando } \\
\text { benefícios fiscais }\end{array}$ \\
\hline $\mathrm{D}$ & V4 & Gera oportunidade para aprimoramento tecnológico e absorção de novos conhecimentos \\
\hline $\mathrm{D}$ & V9 & Propicia portabilidade aos serviços, viabilizando trocas de fornecedores \\
\hline $\mathrm{D}$ & V10 & Possibilita redução global de investimentos e de gastos com custeio de TI \\
\hline $\mathrm{D}$ & V12 & $\begin{array}{l}\text { Aumenta o nível global de segurança em TI, desde que cumpridos os SLA's pelos } \\
\text { fornecedores }\end{array}$ \\
\hline
\end{tabular}

Dentre os quatro benefícios considerados mais importantes, três deles (à exceção daquele que ocupa a segunda posição no ranking) tem como foco e beneficiária direta a própria área de TI. Este fato se justifica, em boa parte, em decorrência de a maioria dos painelistas serem executivos atuantes na área e terem colocado suas próprias expectativas em alta conta, o que não é de todo criticável.

O benefício colocado na segunda posição do ranking destaca-se, então, como o mais relevante sob a ótica dos negócios, traduzindo a visão dos painelistas acerca da importância de disponibilizar novos serviços e aplicativos às suas organizações no mais curto intervalo de tempo possível.

Analisando o ranking na sequência, vê-se que os benefícios que ocupam as posições seguintes contemplam equitativamente a área de TI e a organização como um todo, ao passo que os que foram desconsiderados têm foco integralmente centrado em TI. Esta situação demonstra que, apesar de terem sido considerados como mais importantes três benefícios que trazem em seu bojo vantagens diretas para as áreas de TI, na avaliação global os painelistas tiveram uma postura equilibrada quanto à construção deste ranking, não se atendo exclusivamente a valorizar benefícios em causa própria. 


\subsection{Conclusões Acerca dos Riscos e seu Tratamento}

O capítulo anterior deste documento objetivou apresentar as recomendações destinadas a auxiliar os consumidores de serviços de computação em nuvem a tratar a questão dos riscos inerentes a estes ambientes.

Para suportar essas recomendações, foi feita no tópico 5.1 uma análise detalhada acerca de como os riscos foram tratados pelos painelistas, análise esta que aborda, em linhas gerais, aspectos semelhantes aos explorados nos tópicos acima para as barreiras e os benefícios. Esta análise, portanto, já contempla todos os pontos relevantes que poderiam ser esmiuçados relativamente a este tema.

\subsection{Considerações Finais}

Este estudo objetivou explorar questões relevantes relativas a um tema atual e de importância crescente no campo da TI, a computação em nuvem. A cada dia, e com maior intensidade nestes dois anos mais recentes, a computação em nuvem vem marcando presença crescente entre as opções que se apresentam para o equacionamento das questões relativas à TI por parte das instituições e organizações de negócio. Relembrando a frase de Victor Hugo citada na epígrafe, todas as evidências indicam que a oportunidade da computação em nuvem chegou.

Porém, este é um tema que ainda deixa um tanto desconfortáveis os executivos de TI, quando se deparam com questionamentos acerca da pertinência e da conveniência de contratar, para suas instituições e organizações, serviços oferecidos em ambientes de nuvem não privada.

De fato, a computação em nuvem não é uma novidade simples de ser adotada. Muito pelo contrário, para adotá-la pode ser necessário enfrentar barreiras de difícil transposição, as quais acabam por atuar no sentido de desestimular os mais otimistas executivos de TI. Mas é possível reconhecer e avaliar antecipadamente estas barreiras potenciais e este estudo incumbiu-se de explicitá-las e oferecer aos candidatos à adoção da computação em nuvem um quadro realista do que podem ter que enfrentar. 
Por outro lado, fica evidenciado com esta pesquisa que a computação em nuvem pode trazer benefícios concretos para as instituições e organizações que vierem a aderir a ela. Esta questão fica patente nas conclusões obtidas relativamente aos benefícios passíveis de serem auferidos com a computação em nuvem. Um elenco de benefícios relevantes foi compilado e ordenado neste estudo e pode servir de guia para aqueles que ainda tenham dúvidas ou necessitem justificar sua entrada neste novo ambiente.

Contrapondo-se aos benefícios, os riscos também se apresentam como outro foco de atenção e que, obrigatoriamente, deve ser considerado no processo de avaliação quanto à viabilidade de contratação de soluções em nuvem. Como mencionado no tópico 2.2.1 deste documento, na visão contemporânea, riscos confrontam ameaças com benefícios e sua adequada compreensão e gestão pode confinar as ameaças e abrir caminhos para que se usufrua dos benefícios. Um extenso rol de riscos foi explorado neste estudo, parte deles extraídos da bibliografia consultada e parte aportados pelos painelistas, culminando com a elaboração de um ranking dos 12 riscos considerados mais relevantes. De posse desse ranking e seguindo as recomendações explicitadas no tópico 5.2, instituições, organizações e executivos de TI têm à sua disposição um instrumental capaz de auxiliá-los na compreensão dos riscos inerentes à computação em nuvem e a se autopreparar para gerenciá-los, tornando a contratação de serviços em ambientes de computação em nuvem não privada uma tarefa mais segura.

Acreditamos que, com o trabalho realizado ao longo do painel Delphi, do qual participaram executivos com ampla experiência de atuação em TI e acadêmicos com largo envolvimento com a TI, estes temas - riscos, barreiras e benefícios, que se colocam entre os mais significativos associados à computação em nuvem, foram explorados em todas as suas nuances e chegou-se a resultados práticos de valia.

Deve-se, entretanto, a favor da segurança, tratar com parcimônia os resultados obtidos neste estudo, dadas as limitações impostas pelo método de pesquisa utilizado. Como todo método que se baseia na opinião de um grupo de especialistas secundados por um moderador, o Delphi não está isento de incorporar vícios aos seus resultados, seja pelas restrições impostas pelo tamanho e pela composição do grupo de painelistas, seja pelos conhecimentos efetivos de seus componentes sobre o tema da pesquisa ou ainda por falhas do processo aplicado e/ou de interpretação e de capacidade de análise do moderador. 
Em decorrência, este estudo deixa uma abertura para a realização de pesquisas futuras sobre o tema, com vistas a validar os resultados aqui obtidos, por meio do emprego de métodos que possibilitem realizar inferências e generalizações e que sejam isentos da opinião de um grupo restrito de especialistas e da intervenção de um moderador.

De todo modo, é de se considerar que, com a aplicação de um justo senso crítico, os resultados aqui apresentados possam ser utilizados para minorar os esforços de profissionais de TI e de instituições e organizações que pretendam dar seus primeiros passos no complexo ambiente da computação em nuvem, bem como daqueles que, já devidamente inseridos e partícipes desta opção tecnológica, queiram ou tenham a necessidade de rever conceitos e posições assumidos.

Como contribuição maior, este estudo oferece, acima de tudo, uma visão realista acerca da computação em nuvem e coloca à disposição daqueles que efetivamente por ela se interessam, por vontade própria ou dever de ofício, um rol de observações e recomendações úteis e oportunas. 


\section{REFERÊNCIAS BIBLIOGRÁFICAS}

ARMBRUST, Michael et al. Above the clouds: a Berkeley view of cloud computing. Technical Report No. UCB/EECS-2009-28. Berkeley, CA (US): University of California, Berkeley - Electrical Engineering and Computer Sciences, 2009. Disponível em: <http:// www.eecs.berkeley.edu/Pubs/TechRpts/2009/EECS-2009-28.pdf>. Acesso em 08/07/2010.

AYMERICH, Francesco Maria et al. An aproach to a cloud computing network. In: Proceedings of the 1st International Conference on the Applications of Digital Information and Web Technologies (ICADIWT). Washington, DC (US): IEEE Computer Society, p. 113118, Ago/2008.

BANDYOPADHYAY, Subhajyoti et al. Cloud computing: the business perspective. Disponível em: <http://papers.ssrn.com/sol3/papers.cfm?abstract_id=1413545>. Acesso em 08/07/2010.

BITSCH, Friedemann. Safety patterns - the key to formal specification of safety requirements. In: VOGES, Udo (Org.), Proceedings of the 20th Conference on Computer Safety, Reliability and Security - SAFECOMP (Lecture Notes in Computer Science). Heidelberg: Springer, v. 2187, p. 176-189, 2001.

BORGES, Eline Lima. Tratamento tópico de úlcera venosa: proposta de uma diretriz baseada em evidências. Ribeirão Preto (SP), 2005. Tese (Doutorado em Enfermagem) Programa de Pós-Graduação em Enfermagem, Escola de Enfermagem de Ribeirão Preto da Universidade de São Paulo.

BUYYA, Rajkumar et al. Cloud computing and emerging IT platforms: vision, hype, and reality for delivering computing as the 5th utility. Future Generation Computer Systems. Amsterdam: Elsevier, v. 25, n. 6, p. 599-616, Jun/2009.

CARR, Nicholas G. The big switch: rewiring the world, from Edison to Google. New York, NY (US): W. W. Norton, 2008.

CLOUD SECURITY ALLIANCE (CSA). Security Guidance for Critical Areas of Focus in Cloud Computing - Version 2.1. Cloud Security Alliance, Dez/2009.

COMMITTEE OF SPONSORING ORGANIZATIONS OF THE TREADWAY COMMISSION (COSO). Enterprise risk management - Integrated framework (executive summary). COSO, Set/2004.

COSTA, Janaína Anchieta. Atividades de enfermagem no centro de material e esterilização: subsídios para o dimensionamento de pessoal. São Paulo, 2009. Dissertação (Mestrado em Enfermagem) - Programa de Pós-Graduação em Enfermagem, Escola de Enfermagem da Universidade de São Paulo. 
COSTA E SILVA, Angelo Just da. Método para gestão das atividades de manutenção de revestimentos de fachada. São Paulo, 2008. Tese (Doutorado em Engenharia) - Programa de Pós-Graduação em Engenharia Civil, Departamento de Engenharia de Construção Civil, Escola Politécnica da Universidade de São Paulo.

CROUHY, Michel et al. The essentials of risk management. New York, NY (US): McGrawHill, 2006.

CUNHA, Jacqueline V. A. da. Doutores em Ciências Contábeis da FEA/USP: análise sob a óptica da teoria do capital humano. São Paulo, 2007. Tese (Doutorado em Ciências Contábeis) - Programa de Pós-Graduação em Ciências Contábeis, Departamento de Contabilidade e Atuária, Faculdade de Economia, Administração e Contabilidade da Universidade de São Paulo.

CZINKOTA, Michael R.; RONKAINEN, Ilkka A. International business and trade in the next decade: report from a Delphi study. Journal of International Business Studies. East Lansing, MI (US): Academy of International Business, v. 28, n. 4, p. 827-844, Dez/1997.

DALKEY, Norman C. Delphi. Santa Monica, CA (US): Rand Corporation, Out/1967.

DALKEY, Norman C. The Delphi method: an experimental study of group opinion. Santa Monica, CA (US): Rand Corporation, Jun/1969.

DALKEY, Norman C.; HELMER, Olaf. An experimental application of the Delphi method to the use of experts. Santa Monica, CA (US): Rand Corporation, Jul/1962.

DANTAS, Manuela Modesto. Proposição de ações para melhoria da produtividade da concretagem em edifícios verticais. São Paulo, 2006. Dissertação (Mestrado em Engenharia) - Programa de Pós-Graduação em Engenharia Civil, Departamento de Engenharia de Construção Civil, Escola Politécnica da Universidade de São Paulo.

DELBECQ, Andre L. et al. Group techniques for program planning. Chicago, IL (US): Scott, Foresman, 1975.

ENOKI, Cesar Hidetoshi. Gestão de processos de negócio: uma contribuição para a avaliação de soluções de business process management (BPM) sob a ótica da estratégia de operações. São Paulo, 2006. Dissertação (Mestrado em Engenharia) - Programa de PósGraduação em Engenharia de Produção, Departamento de Engenharia de Produção, Escola Politécnica da Universidade de São Paulo.

EUROPEAN NETWORK AND INFORMATION SECURITY AGENCY (ENISA). Cloud computing: benefits, risks and recommendations for information security. Heraklion: ENISA, Nov/2009. 
EWALD, François. Insurance and risk. In: BURCHELL, Graham et al. The Foucault effect: studies in governmentality. Chicago, IL (US): The University of Chicago Press, p. 197-210, 1991.

F5 NETWORKS. Cloud computing - Survey results. Seattle, WA (US): F5 Networks, $\mathrm{Jul} / 2009$.

FRIEDMAN, Milton. A comparison of alternative tests of significance for the problem of $m$ rankings. The Annals of Mathematical Statistics. Beachwood, OH (US): Institute of Mathematical Statistics, v. 11, n. 1, p. 86-92, Mar/1940.

GATEWOOD, Brent. Clouds on the information horizon: how to avoid the storm. Information Management Journal. Overland Park, KS (US): ARMA International, v. 43, n. 4, p. 32-36, Jul-Ago/2009.

GIMENES, Celso Huerta. Formação de competências gerenciais: um fator de desenvolvimento de lideranças - estudo de caso no IPEN. São Paulo, 2009. Dissertação (Mestrado em Ciências) - Programa de Pós-Graduação em Ciências, Instituto de Pesquisas Energéticas e Nucleares.

GONTIJO, Liliane P. T. Construindo as competências do cirurgião-dentista na atenção primária em saúde. Ribeirão Preto (SP), 2007. Tese (Doutorado em Saúde Pública) Programa de Pós-Graduação em Saúde Pública, Escola de Enfermagem de Ribeirão Preto da Universidade de São Paulo.

GRAEFE, Andreas; ARMSTRONG, J. S. Comparing face-to-face meetings, nominal groups, Delphi and prediction markets on an estimation task. International Journal of Forecasting. Medford, MA (US): International Institute of Forecasters, v. 27, n. 1, p. 183-195, JanMar/2011.

GROSSMAN, Robert L. The case for cloud computing. IT Professional. Washington, DC (US): IEEE Computer Society, v. 11, n. 2, p. 23-27, Mar-Abr/2009.

GUPTA, Uma G.; CLARKE, Robert E. Theory and applications of the Delphi technique: a bibliography. Technological Forecasting and Social Change. Amsterdam: Elsevier, v. 53, n. 2, p. 185-211, Out/1996.

HABEGGER, Beat. Risk analysis and management in a dynamic risk landscape. In: (Org.). International handbook on risk analysis and management. Zurich: ETH Zurich Center for Security Studies (CSS), p. 13-32, 2008.

HALLOWELL, Matthew R.; GAMBATESE, John A. Qualitative research: application of the Delphi method to CEM research. Journal of Construction Engineering and Management. Reston, VA (US): American Society of Civil Engineers, v. 136, n. 1, p. 99-107, Jan/2010. 
HOLSAPPLE, P.; JOSHI, K. Knowledge manipulation activities: results of a Delphi study. Information and Management. Amsterdam: Elsevier, v. 39, n. 6, p. 477-490, Mai/2002.

INTERNATIONAL DATA CORPORATION (IDC). IDC's public IT cloud services forecast: new numbers, same disruptive story. Disponível em: $<\mathrm{http} / / / \mathrm{blogs} . \mathrm{idc} . \mathrm{com} / \mathrm{ie} / \mathrm{p}=$ 922>. Postado por Frank Gens em 01/07/2010. Acesso em 04/11/2010.

INTERNATIONAL ORGANIZATION FOR STANDARDIZATION (ISO). ISO 31000:2009

- Risk management - Principles and guidelines. Geneve: ISO, Nov/2009.

ISAAC, Stephen, MICHAEL, William B. Handbook in research and evaluation. 3rd ed. San Diego, CA (US): Educational and Industrial Testing Services, 1997.

JENSEN, Meiko et al. On technical security issues in cloud computing. In: Proceedings of the IEEE International Conference on Cloud Computing. Washington, DC (US): IEEE Computer Society, p. 109-116, 2009.

JERICHO FORUM. Cloud cube model: selecting cloud formations for secure collaboration. San Francisco, CA (US): Jericho Forum, Abr/2009.

KENDALL, Maurice G. The treatment of ties in ranking problems. Biometrika. Oxford (UK): Biometrika Trust, v. 33, n. 3, p. 239-251, Nov/1945.

KENDALL, Maurice G.; SMITH, Bernard B. The problem of $m$ rankings. The Annals of Mathematical Statistics. Beachwood, OH (US): Institute of Mathematical Statistics, v. 10, n. 3, p. 275-287, Set/1939.

KIM, Won. Cloud computing: today and tomorrow. Journal of Object Technology. Zurich: ETH Zurich, v. 8, n. 1, p. 65-72, Jan-Fev/2009.

KLIEM, Ralph L. Risk management for business process reengineering projects. Information Systems Management. Oxford, UK: Taylor and Francis, v. 17, n. 4, p. 1-3, Set/2000.

KUWABARA, Cleuza C. T. Gerenciamento de risco em tecnovigilância: aplicação dos conceitos Seis Sigma e técnica Delphi para o desenvolvimento e validação de instrumento de avaliação de material médico-hospitalar. Ribeirão Preto (SP), 2009. Tese (Doutorado em Enfermagem) - Programa de Pós-Graduação em Enfermagem, Escola de Enfermagem de Ribeirão Preto da Universidade de São Paulo.

LIMA, Emanoel Marcos. Análise comparativa entre o índice disclosure e a importância atribuída por stakeholders a informações consideradas relevantes para fins de divulgação em instituições de ensino superior filantrópicas do Brasil: uma abordagem da teoria da divulgação. São Paulo, 2009. Tese (Doutorado em Ciências Contábeis) - Programa 
de Pós-Graduação em Ciências Contábeis, Departamento de Contabilidade e Atuária, Faculdade de Economia, Administração e Contabilidade da Universidade de São Paulo.

LINSTONE, Harold A.; TUROFF, Murray. Introduction. In: LINSTONE, Harold A.; TUROFF, Murray (Org.). The Delphi method: techniques and applications. Reading, MA (US): Addison-Wesley, 1975.

LEVESON, Nancy G. Applying systems thinking to analyze and learn from events. Safety Science. Amsterdam: Elsevier, v. 49, n. 1, p. 55-64, Jan/2011 (disponível online em 25/01/2010).

LYRA, Ricardo Luis W. C. de. Análise hierárquica dos indicadores contábeis sob a óptica do desempenho empresarial. São Paulo, 2008. Tese (Doutorado em Ciências Contábeis) Programa de Pós-Graduação em Ciências Contábeis, Departamento de Contabilidade e Atuária, Faculdade de Economia, Administração e Contabilidade da Universidade de São Paulo.

MARKS, Eric A.; LOZANO, Roberto R. Executive's guide to cloud computing. Hoboken, NJ (US): John Wiley, 2010.

MEDEIROS JR., Alberto de. Sistemas integrados de gestão: proposta para um procedimento de decisão multi-critérios para avaliação estratégica. São Paulo, 2007. Tese (Doutorado em Engenharia) - Programa de Pós-Graduação em Engenharia de Produção, Departamento de Engenharia de Produção, Escola Politécnica da Universidade de São Paulo.

MILLER, Michael. Cloud computing: web-based applications that change the way you work and collaborate online. Indianapolis, IN (US): Que Publishing, 2008.

NAKANO, Milton Satocy. Previsão tecnológica a médio e longo prazo sobre os processos de geração de hidrogênio, considerando cenários futuros probabilísticos que levem em conta o desenvolvimento das pilhas a combustível. São Paulo, 2009. Dissertação (Mestrado em Ciências) - Programa de Pós-Graduação em Ciências, Instituto de Pesquisas Energéticas e Nucleares.

NATIONAL INSTITUTE OF STANDARDS AND TECHNOLOGY (NIST). The NIST definition of cloud computing. Gaithersburg, MD (US): NIST, Jul/2009.

OKOLI, Chitu; PAWLOWSKI, Suzanne D. The Delphi method as a research tool: an example, design considerations and applications. Information\&Management. Amsterdam: Elsevier, v. 42, n. 1, p. 15-29, Dez/2004.

OPENCROWD. Cloud taxonomy. New York, NY (US): OpenCrowd, 2010. Disponível em: $<$ http://www.opencrowd.com/assets/images/views/views_cloud-tax-lrg.png $>$. Acesso em 04/11/2010. 
QIAN, Ling et al. Cloud computing: an overview. In: JAATUN, Martin G. et al. (Org.), Proceedings of the 1st Conference on Cloud Computing (Lecture Notes in Computer Science). Heidelberg: Springer, v. 5931, p. 626-631, Dez/2009.

PADILHA, Maria Luiza de M. L. Indicadores de desenvolvimento sustentável para o setor têxtil. São Paulo, 2009. Tese (Doutorado em Saúde Pública) - Programa de Pós-Graduação em Saúde Pública, Faculdade de Saúde Pública da Universidade de São Paulo.

PERROCA, Marcia Galan. Sistema de classificação de pacientes: construção e validação de um instrumento. São Paulo, 1996. Dissertação (Mestrado em Enfermagem) - Programa de Pós-Graduação em Enfermagem, Escola de Enfermagem da Universidade de São Paulo.

RAND CORPORATION. 2004 Annual report: building on a legacy. Santa Monica, CA (US): Rand Corporation, 2005.

RAZ, Tzvi; HILLSON, David. A comparative review of risk management standards. Risk Management: An International Journal. Hampshire, UK: Palgrave Macmillan, v. 7, n. 4, p. 53-66, Out/2005.

RIBEIRO, Maria Alice M. Contribuição ao estudo do impacto ambiental das pilhas a combustível de baixa e média temperatura através da metodologia Delphi. São Paulo, 2009. Tese (Doutorado em Ciências) - Programa de Pós-Graduação em Ciências, Instituto de Pesquisas Energéticas e Nucleares.

ROCHA, Marcos Augusto. Estudo das habilidades técnicas do ataque na posição quatro do voleibol. São Paulo, 2009. Tese (Doutorado em Educação Física e Esporte) - Programa de Pós-Graduação em Educação Física e Esporte, Escola de Educação Física e Esporte da Universidade de São Paulo.

ROWE, Gene et al. Delphi: a reevaluation of research and theory. Technological Forecasting and Social Change. Amsterdam: Elsevier, v. 39, n. 3, p. 235-251, Mai/1991.

ROWE, Gene; WRIGHT, George. The Delphi technique as a forecasting tool: issues and analysis. International Journal of Forecasting. Amsterdam: Elsevier, v. 15, n. 4, p. 353375, Out/1999.

ROWE, Gene; WRIGHT, George. Expert opinions in forecasting: the role of the Delphi technique. In: ARMSTRONG, Jon Scott (Org.), Principles of forecasting: a handbook for researchers and practiotioners (International Series in Operations Research \& Management Sciences). Heidelberg: Springer, v. 30, p. 125-144, 2001.

SANTOS, Carlos Roberto dos. Índice de qualidade laboratorial (IQL): uma proposta para laboratórios de controle ambiental. São Paulo, 2009. Tese (Doutorado em Saúde Pública) Programa de Pós-Graduação em Saúde Pública, Faculdade de Saúde Pública da Universidade de São Paulo. 
SCARPARO, Ariane Fazzolo. Auditoria de enfermagem - identificando sua concepção e métodos. Ribeirão Preto (SP), 2007. Dissertação (Mestrado em Enfermagem) - Programa de Pós-Graduação em Enfermagem, Escola de Enfermagem de Ribeirão Preto da Universidade de São Paulo.

SCHMIDT, Roy C. Managing Delphi surveys using nonparametric statistical techniques. Decision Sciences Journal. Hoboken, NJ (US): Wiley-Blackwell, v. 28, n. 3, p. 763-774, Verão/1997.

SILVA, Luana Torelli da. Construção e validação de um instrumento para avaliação de ocorrência de problemas éticos na atenção básica. São Paulo, 2008. Dissertação (Mestrado em Enfermagem) - Programa de Pós-Graduação em Enfermagem, Escola de Enfermagem da Universidade de São Paulo.

SKULMOSKI, Gregory J. et al. The Delphi method for graduate research. Journal of Information Technology Education, v. 6, p. 1-21, 2007.

SMITH, Roger. Computing in the cloud. Research-Technology Management. Industrial Research Institute, v. 52, n. 5, p. 65-68, Set-Out/2009.

STATEN, James et al. Is cloud computing ready for the enterprise? Cambridge, MA (US): Forrester Research, Mar/2008.

UNITED STATES DEPARTMENT OF DEFENSE. MIL-STD-882D - Standard practice for system safety. Fev/2000.

VELTRI, Anthony. Expected use of management principles for safety function management. Morgantown, WV (US), 1985. Tese (Doutorado) - West Virginia University apud HALLOWELL, Matthew R.; GAMBATESE, John A. Qualitative research: application of the Delphi method to CEM research. Journal of Construction Engineering and Management. Reston, VA (US): American Society of Civil Engineers, v. 136, n. 1, p. 99107, Jan/2010.

VERAS, Manoel. Datacenter: componente central da infraestrutura de TI. Rio de Janeiro: Brasport, 2009.

VERONEZI, Ana Beatriz P. Sistema de certificação da qualidade de edifícios de escritórios no Brasil. São Paulo, 2004. Dissertação (Mestrado em Engenharia) - Programa de Pós-Graduação em Engenharia Civil, Departamento de Engenharia de Construção Civil, Escola Politécnica da Universidade de São Paulo.

VIEHLAND, D.; HUGHES, J. The future of the wireless application protocol. In: Proceedings of the 8th Americas Conference on Information Systems (AMCIS). Dallas, TX (US): Association for Information Systems, p. 1883-1891, Ago/2002. 
VIEIRA, Simone S. da C. Avaliação de programas de educação continuada: análise da percepção do aluno e do seu modelo de decisão para escolha de programas de especialização para executivos no Brasil. São Paulo, 2009. Tese (Doutorado em Ciências Contábeis) Programa de Pós-Graduação em Ciências Contábeis, Departamento de Contabilidade e Atuária, Faculdade de Economia, Administração e Contabilidade da Universidade de São Paulo.

WEISS, Aaron. Computing in the clouds. NetWorker. New York, NY (US): Association for Computing Machinery (ACM), v. 11, n. 4, p. 16-25, Dez/2007.

WENGER, Andreas et al. Preface. In: Habegger, Beat (Org.), International handbook on risk analysis and management. Zurich: ETH Zurich - Center for Security Studies (CSS), 2008.

WESTERMAN, George; HUNTER, Richard. IT risk: turning business threats into competitive advantage. Boston, MA (US): Harvard Business School Press, 2007.

WITT, Regina Rigatto. Competências da enfermeira na atenção básica: contribuição à construção das funções essenciais de saúde pública. Ribeirão Preto (SP), 2005. Tese (Doutorado em Enfermagem) - Programa de Pós-Graduação em Enfermagem, Escola de Enfermagem de Ribeirão Preto da Universidade de São Paulo. 


\section{APÊNDICES}

Apêndice 1 - Dissertações e Teses de Autores Brasileiros Empregando o Método Delphi .. 122 Apêndice 2 - Questionários Aplicados no Painel Delphi ..................................................... 124

Apêndice 3 - Resumo do Perfil dos Painelistas ...................................................................... 138

Apêndice 4 - Variáveis e Fórmulas de Cálculo Relativas ao Painel Delphi.......................... 140 


\section{Apêndice 1 - Dissertações e Teses de Autores Brasileiros Empregando o Método Delphi}

\begin{tabular}{|c|c|c|c|}
\hline Ano & Autor & Área & Título \\
\hline 1996 & $\begin{array}{l}\text { Marcia Galan } \\
\text { Perroca }\end{array}$ & Enfermagem & $\begin{array}{l}\text { Sistema de classificação de pacientes: construção e } \\
\text { validação de um instrumento }\end{array}$ \\
\hline 2004 & $\begin{array}{l}\text { Ana Beatriz Poli } \\
\text { Veronezi }\end{array}$ & $\begin{array}{l}\text { Engenharia } \\
\text { Civil }\end{array}$ & $\begin{array}{l}\text { Sistema de certificação da qualidade de edifícios de } \\
\text { escritórios no Brasil }\end{array}$ \\
\hline 2005 & Eline Lima Borges & Enfermagem & $\begin{array}{l}\text { Tratamento tópico de úlcera venosa: proposta de uma } \\
\text { diretriz baseada em evidências }\end{array}$ \\
\hline 2005 & Regina Rigatto Witt & Enfermagem & $\begin{array}{l}\text { Competências da enfermeira na atenção básica: } \\
\text { contribuição à construção das funções essenciais de saúde } \\
\text { pública }\end{array}$ \\
\hline 2006 & $\begin{array}{l}\text { Cesar Hidetoshi } \\
\text { Enoki }\end{array}$ & $\begin{array}{l}\text { Engenharia de } \\
\text { Produção }\end{array}$ & $\begin{array}{l}\text { Gestão de processos de negócio: uma contribuição para a } \\
\text { avaliação de soluções de BPM sob a ótica da estratégia de } \\
\text { operações }\end{array}$ \\
\hline 2006 & $\begin{array}{l}\text { Manuela Modesto } \\
\text { Dantas }\end{array}$ & $\begin{array}{l}\text { Engenharia } \\
\text { Civil }\end{array}$ & $\begin{array}{l}\text { Proposição de ações para melhoria da produtividade da } \\
\text { concretagem em edifícios verticais }\end{array}$ \\
\hline 2007 & $\begin{array}{l}\text { Alberto de Medeiros } \\
\text { Jr. }\end{array}$ & TI & $\begin{array}{l}\text { Sistemas integrados de gestão: proposta para um } \\
\text { procedimento de decisão multi-critérios para avaliação } \\
\text { estratégica }\end{array}$ \\
\hline 2007 & $\begin{array}{l}\text { Ariane Fazzolo } \\
\text { Scarparo }\end{array}$ & Enfermagem & $\begin{array}{l}\text { Auditoria de enfermagem - identificando sua concepção e } \\
\text { métodos }\end{array}$ \\
\hline 2007 & $\begin{array}{l}\text { Jacqueline Veneroso } \\
\text { Alves da Cunha }\end{array}$ & $\begin{array}{l}\text { Recursos } \\
\text { Humanos }\end{array}$ & $\begin{array}{l}\text { Doutores em Ciências Contábeis da FEA/USP: análise sob } \\
\text { a óptica da teoria do capital humano }\end{array}$ \\
\hline 2007 & $\begin{array}{l}\text { Liliane Parreira } \\
\text { Tannús Gontijo }\end{array}$ & Saúde Pública & $\begin{array}{l}\text { Construindo as competências do cirurgião-dentista na } \\
\text { atenção primária em saúde }\end{array}$ \\
\hline 2008 & $\begin{array}{l}\text { Angelo Just da Costa } \\
\text { e Silva }\end{array}$ & $\begin{array}{l}\text { Engenharia } \\
\text { Civil }\end{array}$ & $\begin{array}{l}\text { Método para gestão das atividades de manutenção de } \\
\text { revestimentos de fachada }\end{array}$ \\
\hline 2008 & $\begin{array}{l}\text { Luana Torelli da } \\
\text { Silva }\end{array}$ & Enfermagem & $\begin{array}{l}\text { Construção e validação de um instrumento para avaliação } \\
\text { de ocorrência de problemas éticos na atenção básica }\end{array}$ \\
\hline 2008 & $\begin{array}{l}\text { Ricardo Luis Wust } \\
\text { Corrêa de Lyra }\end{array}$ & Administração & $\begin{array}{l}\text { Análise hierárquica dos indicadores contábeis sob a óptica } \\
\text { do desempenho empresarial }\end{array}$ \\
\hline 2009 & $\begin{array}{l}\text { Carlos Roberto dos } \\
\text { Santos }\end{array}$ & $\begin{array}{l}\text { Saúde } \\
\text { Ambiental }\end{array}$ & $\begin{array}{l}\text { Índice de qualidade laboratorial (IQL):uma proposta para } \\
\text { laboratórios de controle ambiental }\end{array}$ \\
\hline 2009 & Celso Huerta Gimenes & $\begin{array}{l}\text { Recursos } \\
\text { Humanos }\end{array}$ & $\begin{array}{l}\text { Formação de competências gerenciais: um fator de } \\
\text { desenvolvimento de lideranças - estudo de caso no IPEN }\end{array}$ \\
\hline 2009 & $\begin{array}{l}\text { Cleuza Catsue Takeda } \\
\text { Kuwabara }\end{array}$ & Enfermagem & $\begin{array}{l}\text { Gerenciamento de risco em tecnovigilância: aplicação dos } \\
\text { conceitos Seis Sigma e técnica Delphi para o } \\
\text { desenvolvimento e validação de instrumento de avaliação } \\
\text { de material médico-hospitalar }\end{array}$ \\
\hline 2009 & $\begin{array}{l}\text { Emanoel Marcos } \\
\text { Lima }\end{array}$ & Contabilidade & $\begin{array}{l}\text { Análise comparativa entre o índice disclosure e a } \\
\text { importância atribuída por stakeholders a informações } \\
\text { consideradas relevantes para fins de divulgação em } \\
\text { instituições de ensino superior filantrópicas no Brasil: uma } \\
\text { abordagem da teoria da divulgação }\end{array}$ \\
\hline
\end{tabular}




\begin{tabular}{|c|c|c|c|}
\hline Ano & Autor & Área & Título \\
\hline 2009 & $\begin{array}{l}\text { Janaína Anchieta } \\
\text { Costa }\end{array}$ & Enfermagem & $\begin{array}{l}\text { Atividades de enfermagem no centro de material e } \\
\text { esterilização: subsídios para o dimensionamento de pessoal }\end{array}$ \\
\hline 2009 & $\begin{array}{l}\text { Marcos Augusto } \\
\text { Rocha }\end{array}$ & Esporte & $\begin{array}{l}\text { Estudo das habilidades técnicas do ataque na posição } \\
\text { quatro do voleibol }\end{array}$ \\
\hline 2009 & $\begin{array}{l}\text { Maria Alice Morato } \\
\text { Ribeiro }\end{array}$ & $\begin{array}{l}\text { Tecnologia } \\
\text { Nuclear }\end{array}$ & $\begin{array}{l}\text { Contribuição ao estudo do impacto ambiental das pilhas a } \\
\text { combustível de baixa e média temperatura através da } \\
\text { metodologia Delphi }\end{array}$ \\
\hline 2009 & $\begin{array}{l}\text { Maria Luiza de } \\
\text { Moraes Leonel } \\
\text { Padilha }\end{array}$ & Saúde Pública & $\begin{array}{l}\text { Indicadores de desenvolvimento sustentável para o setor } \\
\text { têxtil }\end{array}$ \\
\hline 2009 & Milton Satocy Nakano & $\begin{array}{l}\text { Tecnologia } \\
\text { Nuclear }\end{array}$ & $\begin{array}{l}\text { Previsão tecnológica a médio e longo prazo sobre os } \\
\text { processos de geração de hidrogênio, considerando cenários } \\
\text { futuros probabilísticos que levem em conta o } \\
\text { desenvolvimento das pilhas a combustível }\end{array}$ \\
\hline 2009 & $\begin{array}{l}\text { Simone Silva da } \\
\text { Cunha Vieira }\end{array}$ & Educação & $\begin{array}{l}\text { Avaliação de programas de educação continuada: análise } \\
\text { da percepção do aluno e do seu modelo de decisão para } \\
\text { escolha de programas de especialização de executivos no } \\
\text { Brasil }\end{array}$ \\
\hline
\end{tabular}




\section{Apêndice 2 - Questionários Aplicados no Painel Delphi}

- Questionário do Ciclo 0

\section{Painel "Computação em Nuvem" -- Rodada 0}

1) Qual o título do seu cargo?

2) Qual o ramo de atividade principal da sua organização?

3) Quantos profissionais com vínculo empregatício trabalham em TI na sua organização?

4) Quantos profissionais terceiros prestam serviços à TI na sua organização?

5) Como você caracteriza seu grau de domínio sobre as disciplinas e conhecimentos a seguir: Pleno Bom Mediano Razoável Mínimo

A TI vista como utilidade (à semelhança da eletricidade, água, esgoto etc.)

Gestão de investimentos em TI

Aquisição de serviços de terceiros em TI

Computação em nuvem

Riscos em TI

Gestão de riscos

6) Qual ou quais, dentre as publicações seguintes, você:

Lê frequentemente Lê esporadicamente

Não lê

Não conhece

InfoExame

Computerworld

Computerworld Brasil

ClO Magazine

ClO Magazine Brasil

InformationWeek

InformationWeek

Brasil

7) Cite, se for o caso, outras publicaçōes näo relacionadas acima e a frequência com que você as lê: 
8) De qual ou quais, dentre os institutos a seguir, você:

Lê as publicações Lê as publicações frequentemente esporadicamente

Não lê as publicações

Não conhece as publicações

Gartner Group

Forrester Research

IDC

Aberdeen

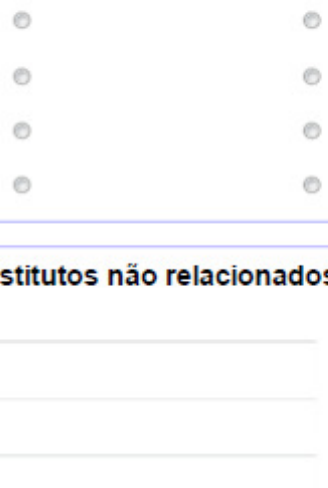

9) Cite, se for o caso, outros institutos não relacionados acima cujas publicações você lê e indique com que frequência:

1.

2.

3.

10) Se você quiser fazer algum comentário adicional sobre este questionário ou complementar as respostas às questóes 7 e 9 , utilize o espaço a seguir.

Material Anexo para Leitura Complementar (opcional)

\section{Uma Introdução à Computação em Nivem}

Na busca por serviços de TI com melhores relações benefício/custo, as organizações empresariais têm optado por mesclar serviços de provimento próprio com os adquiridos de terceiros. Neste último decênio, cresceram e se diversificaram de modo significativo tanto a procura quanto a oferta de serviços de TI por parte de provedores dos mais diversos tipos. De uma oferta, no passado, centrada em recursos de infraestrutura e na cessão de direitos de uso de aplicativos, o leque se abriu para serviços da mais diversa natureza. Esta evolução e diversificação acabaram por propiciar o surgimento de serviços ofertados sob demanda e com a característica de permitir ao tomador optar por adquirir pacotes que englobam tanto recursos de software quanto de hardware e de comunicação, pacotes estes secundados por um compromisso de atendimento dentro de um padrão de nível de serviço. Nesse novo cenário, passa a ser indiferente ao tomador do serviço o local onde fisicamente o processamento ocorre ou mesmo onde os dados são armazenados, importando apenas obter os resultados esperados com o nível de atendimento pactuado.

A computação está se tornando uma utilidade e, uma vez mais, as regras econômicas que determinam o modo de trabalhar e viver das pessoas estão sendo reescritas, à semelhança do que ocorreu no passado, por exemplo, com a eletricidade. Data centers construídos e operados de modo isolado por empresas estão sendo substituídos por serviços providos por instalações centralizadas de processamento de dados num ambiente comum, a Internet. Face às vantagens econômicas do modelo de utilidades, as organizações estão repensando o modo pelo qual se dispõem a comprar e usar $\mathrm{TI}$ - ao invés de destinar um volume expressivo de recursos de caixa para adquirir computadores e programas, estão considerando conectar-se a esse novo ambiente. Trata-se de uma mudança tão significativa que promete não apenas impactar a função de TI das organizações, mas também surpreender a indústria da computação como um todo (CARR, 2008).

Esta nova forma de prestação de serviços de TI foi rotulada "computação em nuvem", expressão traduzida da original em inglês "cloud computing". O instituto de pesquisa Forrester Research elaborou 
um modelo que visa explicar os diferentes estágios da terceirização de serviços de TI, com base na tecnologia aplicada e no modo de ofertá-los. Neste modelo, reproduzido na figura a seguir, a computação em nuvem é referenciada como a modalidade mais evoluída de terceirização de serviços de TI (STATEN et al., 2008).

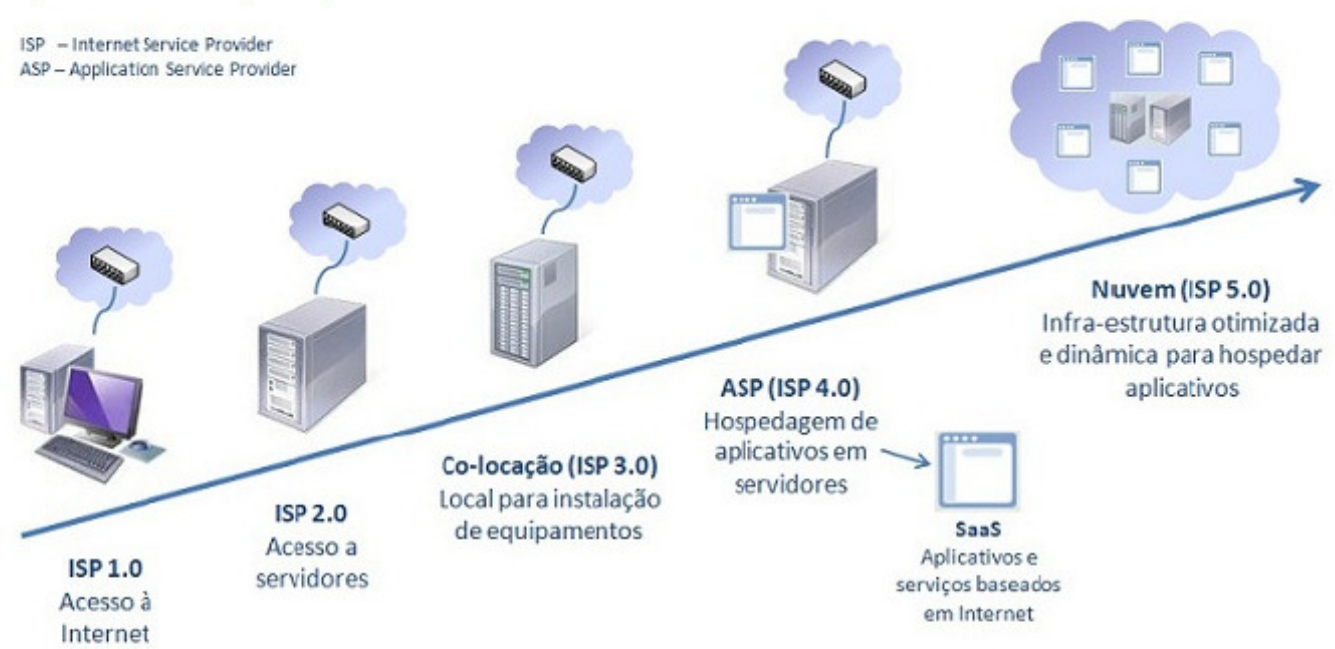

Apesar de se constituir numa modalidade relativamente nova de terceirização de serviços de $\mathrm{Tl}$, a computação em nuvem já conta com um leque bastante razoável de ofertas e provedores. A OpenCrowd (2010), prestadora de serviços de TI, relaciona 18 distintos tipos de serviços oferecidos por meio de nuvens por cerca de duas centenas de provedores. A International Data Corporation, IDC (2010), especializada em estudos na área de TI, projeta um aumento significativo no volume de negócios de computação em nuvem até 2014 .

Exatamente por ser uma modalidade nova de oferta, a computação em nuvem está sujeita às imperfeições e anormalidades que cercam toda novidade e, mais ainda, por se tratar de algo intangível, como é o caso dos serviços. Nessas condições, é natural, e até esperado, que o tomador fique exposto a um nível de risco não muito claro, às vezes excessivo e de difícil mensuração. Têm sido notados esforços por parte da comunidade de provedores no sentido de melhor tratar os riscos inerentes a este novo tipo de oferta e, igualmente, os tomadores de serviços também vêm se organizando, com vistas a exigir níveis mínimos aceitáveis de segurança a serem implementados nas ofertas.

Referências Bibliográficas:

CARR, Nicholas G. The big switch: rewiring the world, from Edison to Google. New York, NY (US): W. W. Norton, 2008. INTERNATIONAL DATA CORPORATION (IDC). IDC's public IT cloud services forecast: new numbers, same disruptive story. Disponível em: . Postado por Frank Gens em 01/07/2010. Acesso em 04/11/2010.

OPENCROWD. Cloud taxonomy. New York, NY (US): OpenCrowd, 2010. Disponivel em: . Acesso em 04/11/2010. STATEN, James et al. Is cloud computing ready for the enterprise? Cambridge, MA (US): Forrester Research, Mar/2008. 
- Questionário do Ciclo 1

\section{Painel "Computação em Nuvem" - Rodada 1}

Neste painel, computação em nuvem será entendida como "um modelo que viabiliza o acesso oportuno e sob demanda a um conjunto de recursos computacionais compartilháveis e configuráveis, que podem ser rapidamente provisionados e liberados com um esforço mínimo de gestão ou de interação com os provedores dos serviços". Esta definição é suportada por um modelo de referência, cujos detalhes estão apresentados no material em anexo ao final deste questionário, material este cuja leitura não é mandatória para fins de entendimento e resposta às questões.

A computação em nuvem vem sendo entendida como um conjunto amplo de serviços e soluções de TI, compreendendo desde aplicativos isolados (na modalidade já há um bom tempo conhecida como SaaS) até soluções completas de terceirização de data centers, que podem englobar SaaS, plataforma (PaaS) e infra-estrutura (laaS). Evidentemente, quanto maior o grau de complexidade da solução, maiores tendem a ser as dificuldades e barreiras para sua implantação e inversamente se apresentam as expectativas quanto aos benefícios que podem ser auferidos.

1) Cite alguns tipos de serviços e soluçöes que você conhece e que se enquadram em cada uma das três modalidades de ofertas de serviços de computação em nuvem.

Saas:

Paas:

laas:

2) Cite, se for o caso, serviços ou soluçöes de computação em nuvem que sua organização utiliza no momento.

3) Cite, se houveram, serviços ou soluçôes de computação em nuvem que sua organização já tenha utilizado e mencione os motivos pelos quais os mesmos foram descontinuados.

4) Cite, se há ou houveram, até 4 dificuldades ou barreiras (sem a necessidade de ordená-las por importância) que estejam impedindo ou já tenham impedido sua organização de contratar serviços de computação em nuvem. Faça um breve comentário sobre cada barreira.

1.

2 .

3. 
5) Se você entende que há mais de 4 barreiras que podem interferir na contratação de serviços de computação em nuvem e que merecem ser citadas, relacione-as a seguir. Faça um breve comentário sobre cada barreira.

Obs.: se você não respondeu à pergunta anterior pelo fato do texto não enquadrar a sua organização, por favor, utilize o espaço desta questão para dar sua opinião sobre este tema.

6) Cite, se há ou haverão, até 4 benefícios (sem a necessidade de ordená-los por importância) que tenham sido obtidos pela sua organização ou que esta espera obter com os serviços de computação em nuvem contratados. Faça um breve comentário sobre cada benefício.

1.

2.

3.

4.

7) Se você entende que há mais de 4 benefícios que podem advir da contratação de serviços de computação em nuvem e que merecem ser citados, relacione-os a seguir. Faça um breve comentário sobre cada benefício.

Obs.: se você não respondeu à pergunta anterior pelo fato do texto não enquadrar a sua organização, por favor, utilize o espaço desta questão para dar sua opiniäo sobre este tema.

8) Se você quiser fazer algum comentário adicional sobre este questionário, utilize o espaço a seguir.

Material Anexo para Leitura Complementar (opcional)

1. Modelo de Referência para Computação em Nuvem 
Modelo de Referência para Computação em Nuvem

\begin{tabular}{|c|c|}
\hline \multicolumn{2}{|c|}{ Dimensäo/Item Detalhe } \\
\hline \multicolumn{2}{|c|}{ Caracteristicas Essenciais } \\
\hline $\begin{array}{l}\text { Auto-serviç } \\
\text { sob demanda }\end{array}$ & $\begin{array}{l}\text { Os consumidores podem, unilateralmente, provisiocar cspacidade conputacional, à } \\
\text { medida das necessidades e sutomaticamente, sem que seja requerida intera̧̧ăo humans } \\
\text { com os provedoras dos sorviços. }\end{array}$ \\
\hline $\begin{array}{l}\text { Acesso amplo } \\
\text { à rede }\end{array}$ & $\begin{array}{l}\text { Capacidadas estâo disponíveis na rede e sâo acessadas por meio de mecanismos } \\
\text { padronizados que possibilitam o uso via distintas plataformas de hardwase. }\end{array}$ \\
\hline $\begin{array}{l}\text { Agrupamento } \\
\text { derecursos }\end{array}$ & 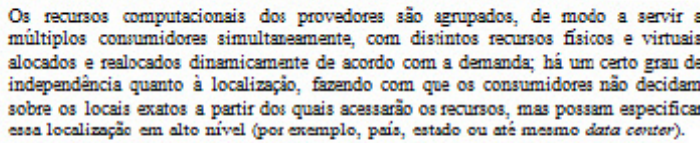 \\
\hline $\begin{array}{l}\text { Rápida } \\
\text { elasticidade }\end{array}$ & $\begin{array}{l}\text { As capacidades podem ser rápida e elasticamente provisionsdas, em alguns caso } \\
\text { de forma sutonática, permitindo sumentar e reducir dinamicamente as quantic } \\
\text { contratadas; pera um consumidor, as capacidades disponiveis para provisionam } \\
\text { spresentam-se como praticamente ilimitadas e podem ser compradas em qual } \\
\text { quantidade a qualquer momento. }\end{array}$ \\
\hline $\begin{array}{l}\text { Serviços } \\
\text { mensuráveis }\end{array}$ & $\begin{array}{l}\text { Sistemss em muvem s } \\
\text { por meio de mecanis } \\
\text { gssim, o uso dos recurs }\end{array}$ \\
\hline \multicolumn{2}{|c|}{ Ofertas de Serviços } \\
\hline $\begin{array}{l}\text { Software } \\
\text { como servipg } \\
\text { (Sas) }\end{array}$ & 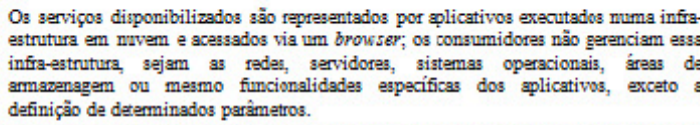 \\
\hline $\begin{array}{l}\text { Plataforma } \\
\text { como servipo } \\
\text { (PasS) }\end{array}$ & 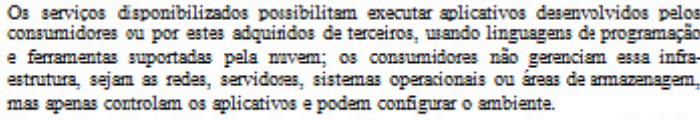 \\
\hline $\begin{array}{l}\text { Infra-estrutura } \\
\text { como servips } \\
\text { (IasS) }\end{array}$ & 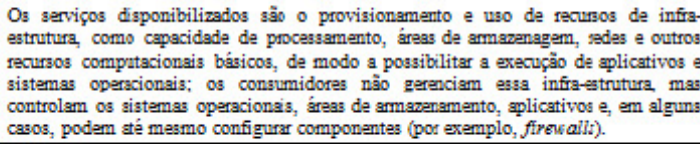 \\
\hline \multicolumn{2}{|c|}{ Modelos de Implementacåa } \\
\hline $\begin{array}{l}\text { Nuvem } \\
\text { Privada }\end{array}$ & $\begin{array}{l}\text { A infra-estrutusa em nuvem é } \\
\text { ela ou por terceiros e pode ests }\end{array}$ \\
\hline $\begin{array}{l}\text { Nuvem } \\
\text { Comunitária }\end{array}$ & $\begin{array}{l}\text { infra-estrutura em nuvem é compartilhada por várias organizaçōes que compōem } \\
\text { ma comunideda espacifica, poda ser gerida por membros dessa comunidade ou por } \\
\text { aceiros e podt estar ou nJo instalada em local próprio dessa comunidade. }\end{array}$ \\
\hline $\begin{array}{l}\text { Nuvem } \\
\text { Pública }\end{array}$ & $\begin{array}{l}\text { infra-estrutura em nuvem é de propriedade de una organizaçäo qua se propõe a } \\
\text { omercializar os recursos es disponibiliza sos consumidores em geral. }\end{array}$ \\
\hline $\begin{array}{l}\text { Nuvem } \\
\text { Hibrida }\end{array}$ & 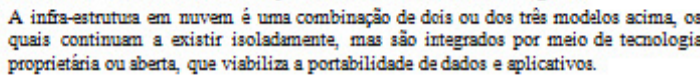 \\
\hline
\end{tabular}

FONTE: Adsptado de National Institute of Standards and Technology (NST).

2. Representação Gráfica do Modelo de Referência

Representação Gráfica do Modelo do NIST para Computação em Nuvem

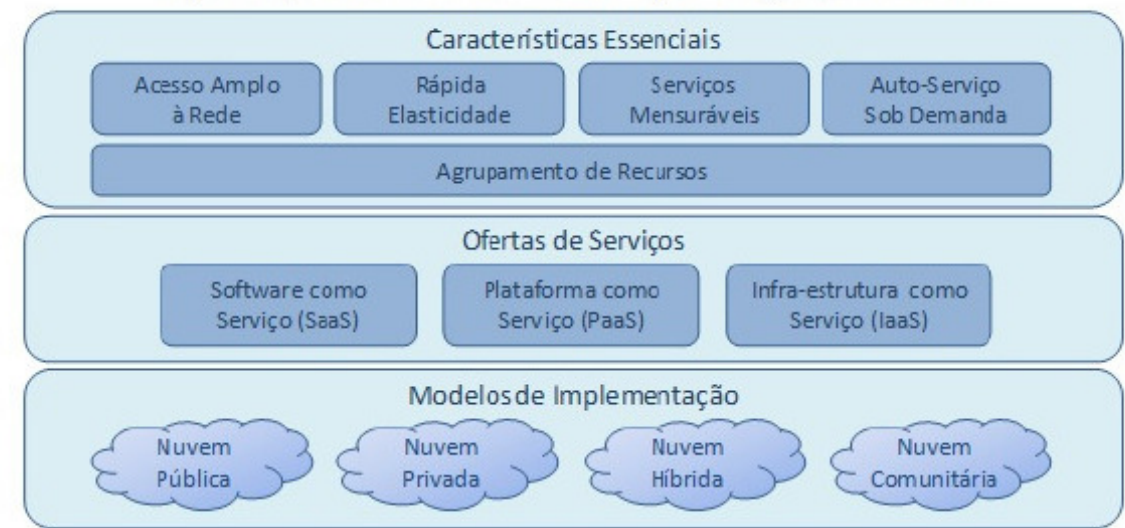

FONTE: Adaptado de Cloud Security Alliance (CSA). 
- Questionário do Ciclo 2

\section{Painel "Computação em Nuvem" - Rodada 2}

1) A compilação das respostas dadas ao questionário da rodada anterior levou à obtenção de uma lista contendo 16 barreiras potenciais inerentes à computação em nuvem.

Considerando essa lista, apresentada a seguir, indique as 10 barreiras que você considera mais importantes, quando se analisa a perspectiva de contratar uma solução de computação em nuvem não privada, isto é, não utilizada por uma única empresa isoladamente.

Sim, esta é uma Não, esta não é das $10 \quad$ uma das 10

Maturidade ainda não comprovada do modelo de serviços e governança, por ser muito novo

Riscos inerentes ao modelo de serviços, muitos dos quais ainda desconhecidos e que podem não ser adequadamente esclarecidos pelo fornecedor

Oferta de serviços ainda limitada

Custo elevado dos serviços ofertados

Dúvidas quanto à segurança que possa vir a ser oferecida pelo formecedor

Dúvidas quanto à capacidade do fornecedor em garantir disponibilidade e dispor de recursos para atender a contingências

Dúvidas quanto à qualidade dos recursos de infra-estrutura e rede de comunicações adotados pelo fornecedor

Dúvidas quanto à capacidade do fornecedor em realizar em tempo hábil a implantação e expansão dos serviços contratados

Dúvidas quanto à capacidade do fornecedor em atender a urgências

Dúvidas quanto à capacidade e agilidade do fornecedor em prover suporte

Dúvidas quanto à capacidade do fornecedor em negociar satisfatoriamente e atender a SLA's

Dúvidas quanto ao tratamento a ser recebido de parte do fomecedor, face à eventual baixa representatividade dos serviços contratados

Receio quanto à comunicação com um fornecedor estrangeiro, por conta de dificuldades com o idioma

Falta de cultura por parte do comprador

Investimentos recentes realizados pelo comprador em infra-estrutura própria

Dúvidas quanto à viabilidade da terceirização de determinados serviços, em função de criticidade dos negócios e necessidade de controle

2) Do mesmo modo, a compilação das respostas dadas ao questionário da rodada anterior levou à obtenção de uma lista contendo 12 benefícios potenciais inerentes à computação em nuvem. Adicionalmente, diversos autores que têm pesquisado a computação em nuvem reportam em seus escritos alguns benefícios não citados pelos painelistas, dentre os quais os mais relevantes são o acesso facilitado a inovações e a menor mobilização de recursos destinados a $\mathrm{TI}$.

Considerando, então, a lista apresentada a seguir, indique os 10 benefícios que você considera mais importantes, quando se analisa a perspectiva de contratar uma solução de computação em nuvem não privada.

Sim, este é um Não, este não é dos $10 \quad$ um dos 10

Permite concentrar o foco de TI nos negócios e em processos core

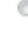


Propicia maior simplicidade e menor esforço para gerir os ativos alocados a TI

Reduz ou elimina a necessidade de lidar com planejamento de capacidade e outros processos associados a ativos próprios

Gera oportunidade para aprimoramento tecnológico e absorção de novos conhecimentos

Demanda investimentos iniciais menores para se dispor do mesmo nível de recursos e tecnologia

Viabiliza a implantação mais rápida de novos serviços e aplicativos

Confere maior grau de disponibilidade aos serviços

Oferece escalabilidade, proporcionando flexibilidade para crescer e lidar com situações de pico e sazonalidade

Propicia portabilidade aos serviços, viabilizando trocas de fornecedores

Possibilita redução global de investimentos e de gastos com custeio de TI

Permite substituir investimentos em ativos (CAPEX) por despesas (OPEX), gerando benefícios fiscais

Aumenta o nível global de segurança em $\mathrm{Tl}$, desde que cumpridos os SLA's pelos fornecedores

Facilita o acesso a inovações, tomando possivel utilizar novos tipos de aplicativos e serviços não possiveis em outras condições

Propicia menor mobilização de recursos de pessoal e infra-estrutura para TI

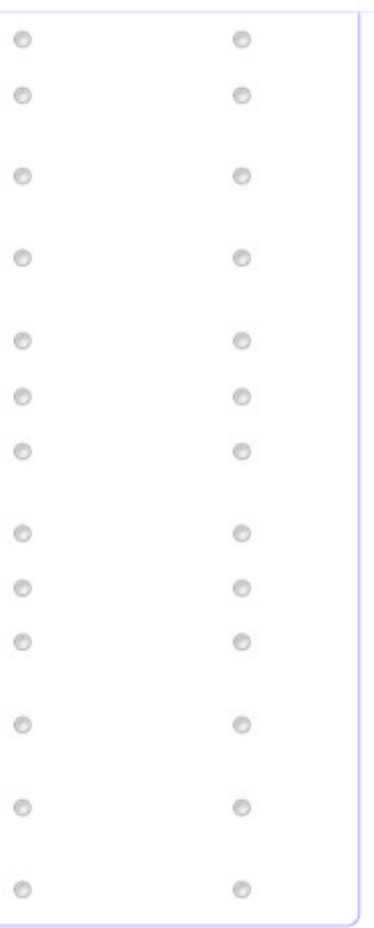

3) Além dos tópicos dos benefícios e barreiras, há outro tema importante na pauta das discussōes sobre computação em nuvem. Trata-se do risco, que é um dos aspectos que mais têm chamado a atenção das empresas que analisam a possibilidade de adquirir serviços de computação em nuvem, seja por se tratar de um mercado de serviços novo e, portanto, não totalmente consolidado, seja pelo fato de muitos provedores adotarem discursos comerciais sempre adaptados aos modismos do momento (o que gera desconfianças) ou ainda por outros motivos de foro particular.

O risco pode ser visto como o elemento que segrega a segurança do perigo, ou seja, até um limite aceitável de risco, pode-se dizer que se está em uma situação de segurança e, acima desse limite, adentra-se num ambiente perigoso. Este limite é relativo, isto é, depende de cada situação e contexto em particular e pode ser expresso em função do grau de exposição aos riscos que são relevantes numa dada situação.

Feitas estas consideraçöes, cite (sem a necessidade de ordená-los por importância) até 6 riscos que, na sua opinião, devem ser considerados quando se avalia contratar uma solução de computação em nuvem não privada. Dê uma breve definição para cada risco.

1.

2.

3 .

4.

5 .

6.

4) Se você considera que, além dos riscos acima relacionados, há outros que também mereçam ser citados, utilize o espaço abaixo para tal.

5) Se você quiser fazer algum comentário adicional sobre este questionário, utilize o espaço a seguir. 
- Questionário do Ciclo 3

\section{Painel "Computação em Nuvem" - Rodada 3}

1) A compilação das respostas dadas ao questionário da rodada anterior levou à obtenção de uma lista contendo as 10 barreiras potenciais inerentes à computação em nuvem entendidas pelos painelistas como sendo as mais relevantes, quando se analisa a perspectiva de contratar uma solução de computação em nuvem não privada, isto é, não utilizada por uma única empresa isoladamente.

Considerando essa lista, apresentada a seguir, indique a importância relativa dessas 10 barreiras, classificando-as da mais importante (número 1) para a menos (número 10).

Maturidade ainda não comprovada do modelo de serviços e governança, por ser muito novo

Riscos inerentes ao modelo de serviços, muitos dos quais ainda desconhecidos e que podem não ser adequadamente esclarecidos pelo fornecedor

Oferta de serviços ainda limitada

Dúvidas quanto à segurança que possa vir a ser oferecida pelo fornecedor

Dúvidas quanto à capacidade do fornecedor em garantir disponibilidade e dispor de recursos para atender a contingências Dúvidas quanto à capacidade do fornecedor em atender a urgências Dúvidas quanto à capacidade e agilidade do fornecedor em prover suporte

Dúvidas quanto à capacidade do fornecedor em negociar satisfatoriamente e atender a SLA's

Investimentos recentes realizados pelo comprador em infra-estrutura própria

Dúvidas quanto à viabilidade da terceirização de determinados serviços, em função de criticidade dos negócios e necessidade de controle

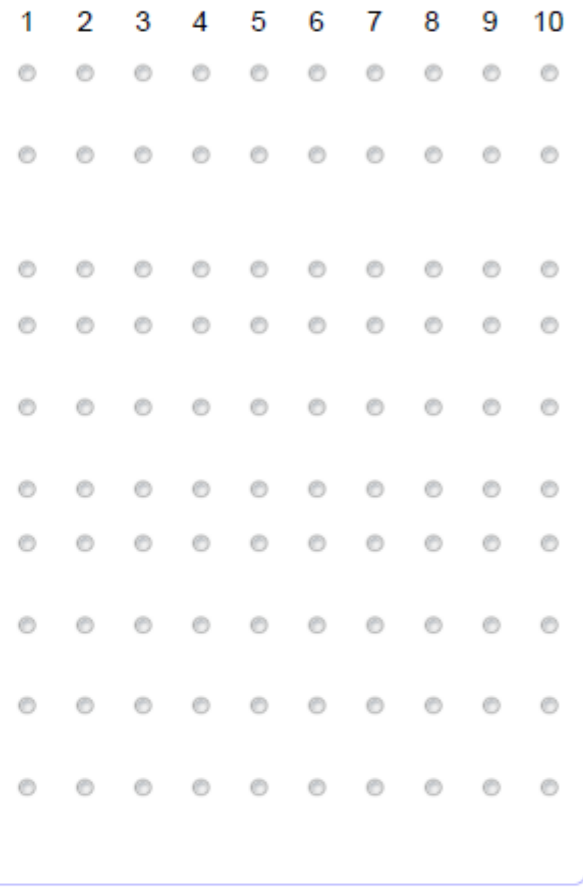

2) Do mesmo modo, a compilação das respostas dadas ao questionário da rodada anterior levou à obtenção de uma lista contendo os 10 benefícios potenciais inerentes à computação em nuvem entendidos pelos painelistas como sendo os mais relevantes, quando se analisa a perspectiva de contratar uma solução de computação em nuvem não privada, isto é, não utilizada por uma única empresa isoladamente.

Considerando essa lista, apresentada a seguir, indique a importância relativa desses 10 benefícios, classificando-os do mais importante (número 1) para o menos (número 10).

Permite concentrar o foco de TI nos negócios e em processos core

Propicia maior simplicidade e menor esforço para gerir os ativos alocados a $\mathrm{Tl}$

Reduz ou elimina a necessidade de lidar com planejamento de capacidade e outros processos associados a ativos próprios

Demanda investimentos iniciais menores para se dispor do mesmo nível de recursos e tecnologia

Viabiliza a implantação mais rápida de novos serviços e aplicativos Confere maior grau de disponibilidade aos serviços

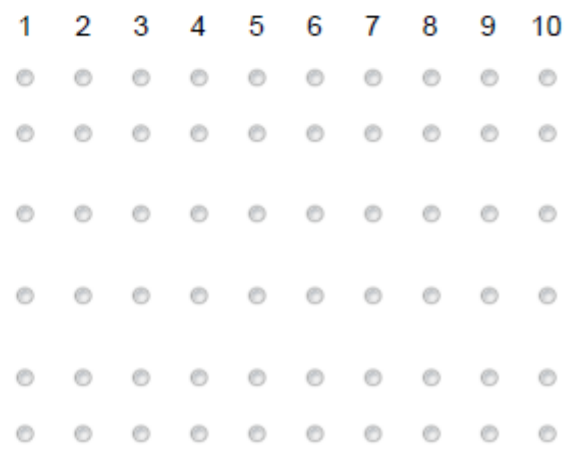


Oferece escalabilidade, proporcionando flexibilidade para crescer e lidar com situações de pico e sazonalidade

Permite substituir investimentos em ativos (CAPEX) por despesas (OPEX), gerando benefícios fiscais

Facilita o acesso a inovações, tomando possível utilizar novos tipos de aplicativos e serviços não possiveis em outras condições

Propicia menor mobilização de recursos de pessoal e infra-estrutura para $\mathrm{Tl}$

3) A compilação das respostas dadas ao questionário da rodada anterior levou também à obtenção de uma lista contendo 15 riscos potenciais inerentes à computação em nuvem. Adicionalmente, diversos autores que têm pesquisado a computação em nuvem reportam em seus escritos alguns riscos não citados pelos painelistas, dentre os quais os mais relevantes são a não-conformidade, o licenciamento de software, a má reputação do provedor, a deficiência de integridade e a vulnerabilidade a ataques por saturação.

Considerando, então, a lista apresentada a seguir, indique os 12 riscos que você entende como sendo os mais importantes, quando se analisa a perspectiva de contratar uma solução de computação em nuvem não privada.

Falta de privacidade: baixo grau de confidencialidade e deficiências de isolamento no ambiente da nuvem, possibilitando acessos indevidos e/ou adulteração de dados e/ou aplicativos de consumidores

Erros: falhas que implicam na necessidade de reprocessar rotinas e/ou recuperar dados

Suporte inadequado: falhas de natureza diversa no serviço de suporte, tais como pessoal mal preparado, gargalos no atendimento, indisponibilidade do serviço etc.

Baixo desempenho: desempenho insatisfatório dos serviços contratados (devido a picos de demanda, balanceamento inadequado, subdimensionamento dos recursos, alta latência de rede e outros fatores assemelhados), levando ao descumprimento dos SLA's

Dificuldade para escalar: demora excessiva ou dificuldades do provedor para provisionar e/ou liberar recursos da nuvem

Indisponibilidade: interrupção temporária dos serviços em decorrência de problemas técnicos ou de ordem diversa de parte do provedor

Não-continuidade: interrupção definitiva da prestação dos serviços pelo provedor

Aprisionamento: dificuldade significativa ou, no limite, impossibilidade de trocar de provedor, devido a particularidades do ambiente e/ou aspectos contratuais

Baixa interoperabilidade: dificuldade significativa ou, no limite, impossibilidade de intercambiar dados e/ou aplicativos entre distintos provedores

Govemança inadequada: modelo de governança adotado pelo provedor possui lacunas e/ou pontos falhos e não atende às necessidades impostas pelos contratos acordados com seus clientes

Incapacidade: baixa capacidade e/ou inexperiência do provedor para prestar serviços da natureza dos ofertados em ambientes de computação em nuvem

Imaturidade do modelo: baixa maturidade do modelo de prestação de serviços em nuvem por ser muito recente, podendo gerar exposição indevida para os gestores de TI dos clientes

Mentalidade invariante: dificuldade do provedor em adotar uma postura distinta frente às necessidades e demandas por serviços de diferentes graus de relevância para os consumidores (por exemplo, serviços de agenda e correio eletrônico versus ERP)

Dificuldade para integrar: dificuldade significativa ou, no limite, impossibilidade de integrar diferentes aplicativos de um mesmo ou de distintos fornecedores

Falta de visibilidade: baixa visibilidade ou, no limite, ausência total de visibilidade acerca dos ativos e recursos disponibilizados pelo provedor

Deficiência de integridade: permissividade para a introdução fraudulenta de agentes de software com funções destinadas a provocar o mau funcionamento de serviços operados na nuvem

Vulnerabilidade a ataques por saturação: não detecção em tempo hábil de ataques que geram sobrecarga dos servidores ao tentar interpretar solicitações sem sentido que desestabilizam o ambiente

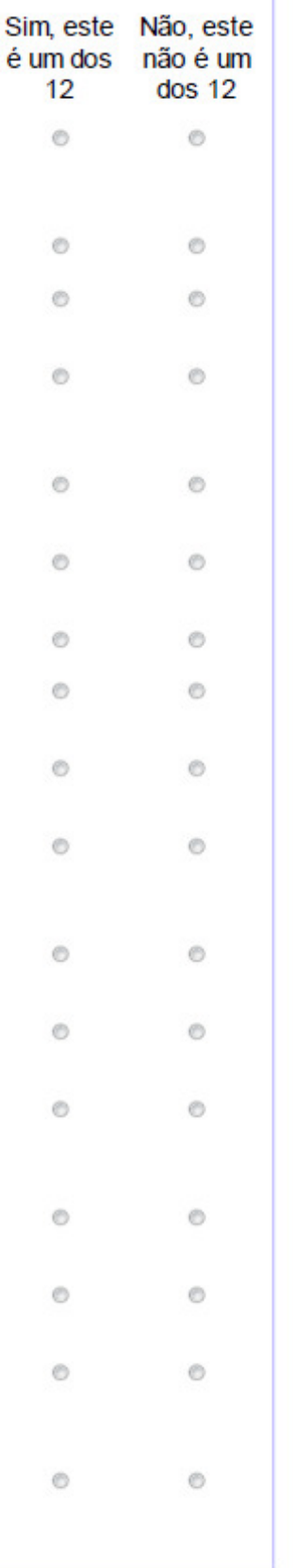


Não-conformidade: não atendimento a aspectos ditados pela legislação ou disciplinados por padrões de larga aceitação na indústria

Licenciamento de software: limitações impostas ao provedor por contratos de licenciamento de software inadequadamente pactuados com seus fornecedores

Má reputação: ampla repercussão de aspectos negativos envolvendo a prestação de serviços a um determinado consumidor ou a um grupo de consumidores

4) Se você quiser fazer algum comentário adicional sobre este questionário, utilize o espaço a seguir. 


\section{Painel "Computação em Nuvem" - Rodada 4}

1) A compilação das respostas dadas ao questionário da rodada anterior levou à obtenção de uma lista contendo os 12 riscos potenciais inerentes à computação em nuvem entendidos pelos painelistas como sendo os mais relevantes, quando se analisa a perspectiva de contratar uma solução de computação em nuvem não privada, isto é, não utilizada por uma única empresa isoladamente.

Considerando essa lista, apresentada a seguir, indique a importância relativa desses 12 riscos, classificando-os do mais importante (número 1) para o menos (número 12).

Falta de privacidade: baixo grau de confidencialidade $\mathrm{e}$ deficiências de isolamento no ambiente da nuvem, possibilitando acessos indevidos e/ou adulteração de dados e/ou aplicativos de consumidores

Suporte inadequado: falhas de natureza diversa no serviço de suporte, tais como pessoal mal preparado, gargalos no atendimento, indisponibilidade do serviço etc.

Baixo desempenho: desempenho insatisfatório dos serviços contratados (devido a picos de demanda, balanceamento inadequado, subdimensionamento dos recursos, alta latência de rede e outros fatores assemelhados), levando ao descumprimento dos SLA's

Dificuldade para escalar: demora excessiva ou dificuldades do provedor para provisionar e/ou liberar recursos da nuvem Indisponibilidade: interrupção temporária dos serviços em decorrência de problemas técnicos ou de ordem diversa de parte do provedor

Não-continuidade: interrupção definitiva da prestação dos serviços pelo provedor

Aprisionamento: dificuldade significativa ou, no limite, impossibilidade de trocar de provedor, devido a particularidades do ambiente e/ou aspectos contratuais

Baixa interoperabilidade: dificuldade significativa ou, no limite, impossibilidade de intercambiar dados e/ou aplicativos entre distintos provedores

Incapacidade: baixa capacidade e/ou inexperiência do provedor para prestar serviços da natureza dos ofertados em ambientes de computação em nuvem

Imaturidade do modelo: baixa maturidade do modelo de prestação de serviços em nuvem por ser muito recente, podendo gerar exposição indevida para os gestores de $\mathrm{TI}$ dos clientes

Dificuldade para integrar: dificuldade significativa ou, no limite, impossibilidade de integrar diferentes aplicativos de um mesmo ou de distintos fornecedores

Não-conformidade: não atendimento a aspectos ditados pela legislação ou disciplinados por padrões de larga aceitação na indústria

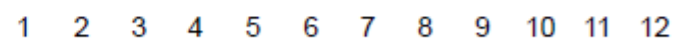

(Q) ค- की

(1)


2) Na rodada anterior, você ordenou por importância as 10 barreiras potenciais mais relevantes, quando se analisa a perspectiva de contratar uma solução de computação em nuvem não privada. Depois de compiladas as indicações de todos os painelistas, obteve-se um ranking coletivo, o qual retrata a visão do grupo a respeito deste tema. As barreiras apresentadas abaixo estão na ordem deste ranking coletivo e, entre parênteses ao lado esquerdo de cada uma delas, estão registradas as posições correspondentes no seu ranking.

O coeficiente de concordância, que é uma variável estatística que mede o grau de concordância entre ordenaçöes feitas por diferentes individuos (e que pode assumir valores entre $0 \mathrm{e} 1$ ), foi calculado para este conjunto de rankings individuais e o valor obtido foi 0,2274 , o que permite afirmar que há uma baixa concordância entre os painelistas quanto a este tema. A baixa concordância ocorre para valores deste coeficiente entre 0,1 e 0,3.

Analisando comparativamente seu ranking e o coletivo, você faria alguma modificação nas suas indicações? Se sim, marque nas colunas à direita seu ranking revisado. Se não, simplesmente pule esta questão.

1. ( ) Dúvidas quanto à viabilidade da terceirização de determinados serviços, em função de criticidade dos negócios e necessidade de controle

2. () Riscos inerentes ao modelo de serviços, muitos dos quais ainda desconhecidos e que podem não ser adequadamente esclarecidos pelo fornecedor

3. ( ) Maturidade ainda não comprovada do modelo de serviços e governança, por ser muito novo

4. ( ) Dúvidas quanto à segurança que possa vir a ser oferecida pelo fornecedor

5. ( ) Dúvidas quanto à capacidade do fornecedor em atender a urgências

6. ( ) Dúvidas quanto à capacidade do fornecedor em negociar satisfatoriamente e atender a SLA's

7. ( ) Dúvidas quanto à capacidade e agilidade do fornecedor em prover suporte

8. ( ) Dúvidas quanto à capacidade do fornecedor em garantir disponibilidade e dispor de recursos para atender a contingências

9. ( ) Oferta de serviços ainda limitada

10. ( ) Investimentos recentes realizados pelo comprador em infraestrutura própria

3) Do mesmo modo, na rodada anterior, você ordenou por importância os 10 benefícios potenciais mais relevantes, quando se analisa a perspectiva de contratar uma solução de computação em nuvem não privada. Depois de compiladas as indicações de todos os painelistas, aqui também se obteve um ranking coletivo. Os beneficios apresentados abaixo estão na ordem deste ranking coletivo e, entre parênteses ao lado esquerdo de cada um deles, estão registradas as posiçöes correspondentes no seu ranking.

O coeficiente de concordância foi também calculado para este conjunto de rankings individuais e o valor obtido foi 0,1435 , o que permite afirmar que, uma vez mais, há uma baixa concordância entre os painelistas quanto a este tema.

Analisando comparativamente seu ranking e o coletivo, você faria alguma modificação nas suas indicações? Se sim, marque nas colunas à direita seu ranking revisado. Se não, simplesmente pule esta questão.

1. ( ) Viabiliza a implantação mais rápida de novos serviços e aplicativos

2. ( ) Permite concentrar o foco de TI nos negócios e em processos core

3. ( ) Demanda investimentos iniciais menores para se dispor do mesmo nivel de recursos e tecnologia 
4. ( ) Propicia maior simplicidade e menor esforço para gerir os ativos alocados a TI

5. ( ) Reduz ou elimina a necessidade de lidar com planejamento de capacidade e outros processos associados a ativos próprios

6. ( ) Facilita o acesso a inovações, tornando possível utilizar novos tipos de aplicativos e serviços não possiveis em outras condições

7. ( ) Permite substituir investimentos em ativos (CAPEX) por despesas (OPEX), gerando benefícios fiscais

8. ( ) Oferece escalabilidade, proporcionando flexibilidade para crescer e lidar com situações de pico e sazonalidade

9. ( ) Propicia menor mobilização de recursos de pessoal e infraestrutura para TI

10. ( ) Confere maior grau de disponibilidade aos serviços

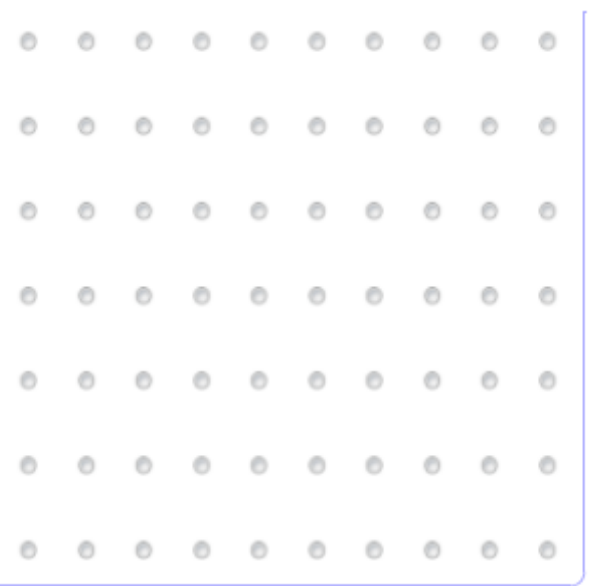

4) Se você quiser fazer algum comentário adicional sobre este questionário, utilize o espaço a seguir.

Nota: foram preparados e enviados questionários individuais personalizados, incluindo entre os parênteses presentes nos itens das questões 2 e 3 (que no modelo aparecem sem conteúdo) os rankings específicos de cada painelista. 


\section{Apêndice 3 - Resumo do Perfil dos Painelistas}

- Acadêmicos:

\begin{tabular}{|c|c|c|c|}
\hline & Formação & Atividades Acadêmicas & Atividades Complementares \\
\hline 1 & $\begin{array}{l}\text { - Administrador de Empresas } \\
\text { - Especializado em Economia } \\
\text { - Mestre e Doutor em Administração } \\
\text { de Empresas }\end{array}$ & $\begin{array}{l}\text { - Professor em cursos de } \\
\text { graduação e pós-graduação } \\
\text { na Universidade Federal do } \\
\text { Rio Grande do Sul }\end{array}$ & $\begin{array}{l}\text { - Coordenador Adjunto do } \\
\text { Programa de Doutorado em } \\
\text { Administração da } \\
\text { Universidade Federal do Rio } \\
\text { Grande do Sul }\end{array}$ \\
\hline 2 & $\begin{array}{l}\text { - Engenheiro Mecânico de Produção } \\
\text { - Pós-Graduado em Administração } \\
\text { de Empresas } \\
\text { - Mestre e Doutor em Administração } \\
\text { de Empresas, com ênfase em } \\
\text { Sistemas de Informação }\end{array}$ & $\begin{array}{l}\text { - Professor em cursos de } \\
\text { graduação e especialização } \\
\text { para graduados na Escola de } \\
\text { Administração de Empresas } \\
\text { de São Paulo da Fundação } \\
\text { Getúlio Vargas } \\
\text { - Professor do MBA da } \\
\text { Business School de São } \\
\text { Paulo }\end{array}$ & $\begin{array}{l}\text { - Consultor autônomo nas } \\
\text { áreas de tecnologia da } \\
\text { informação, reestruturação } \\
\text { organizacional, } \\
\text { desenvolvimento de } \\
\text { atividades empresariais, } \\
\text { desenho e implantação de } \\
\text { sistemas de planejamento e } \\
\text { controle e investimentos }\end{array}$ \\
\hline 3 & $\begin{array}{l}\text { - Engenheiro e Mestre em } \\
\text { Engenharia Elétrica } \\
\text { - Doutor em Administração de } \\
\text { Empresas }\end{array}$ & $\begin{array}{l}\text { Professor em cursos de } \\
\text { graduação, especialização } \\
\text { para graduados e pós- } \\
\text { graduação na Universidade } \\
\text { Federal do Rio Grande do } \\
\text { Norte }\end{array}$ & $\begin{array}{l}\text { - Coordenador de cursos de } \\
\text { especialização na } \\
\text { Universidade Federal do Rio } \\
\text { Grande do Norte }\end{array}$ \\
\hline
\end{tabular}

- Profissionais de TI:

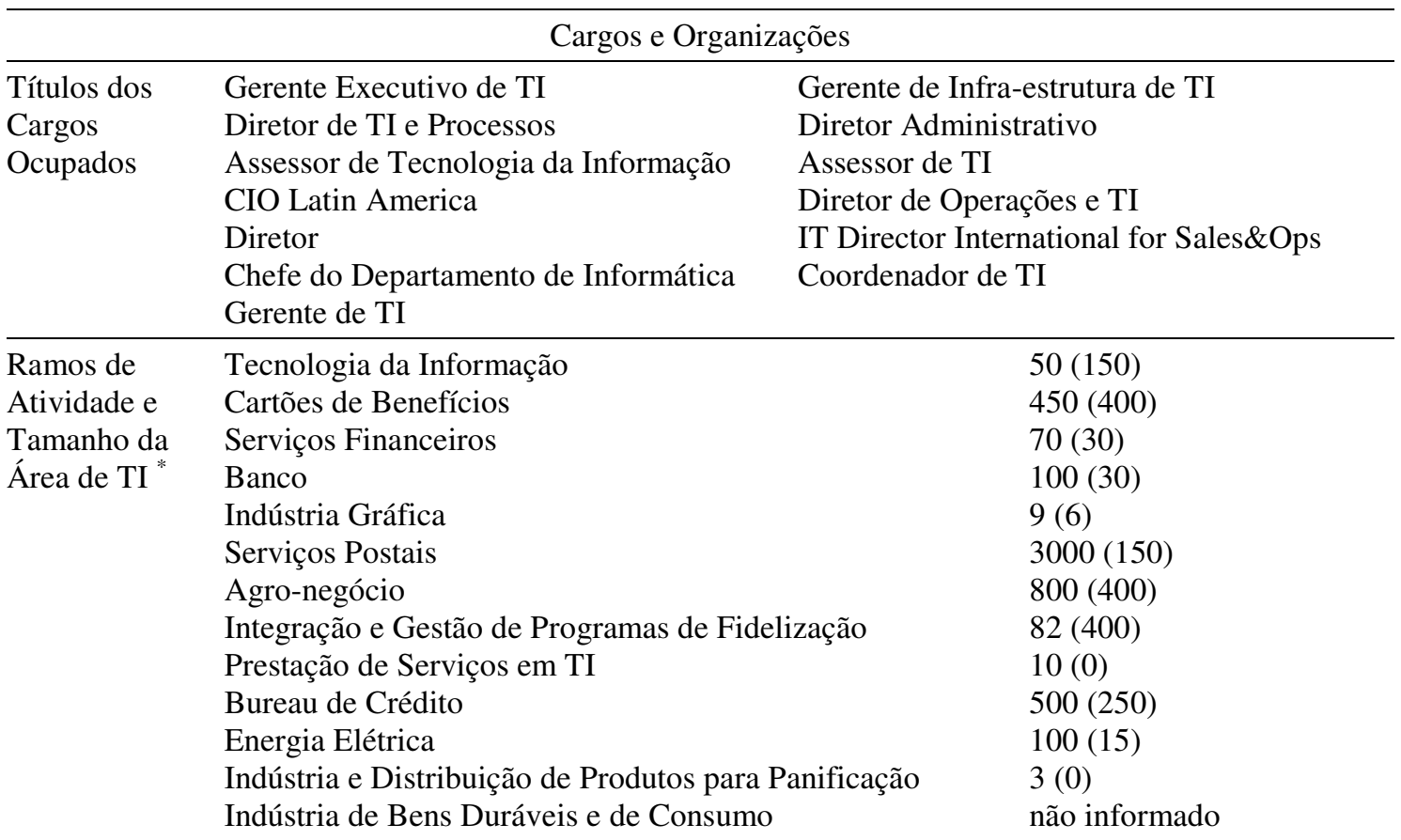

* Os números à frente dos ramos de atividade indicam as quantidades de profissionais alocados à atividade de TI, funcionários contratados e terceiros, estes entre parênteses. 
Qualificação Profissional

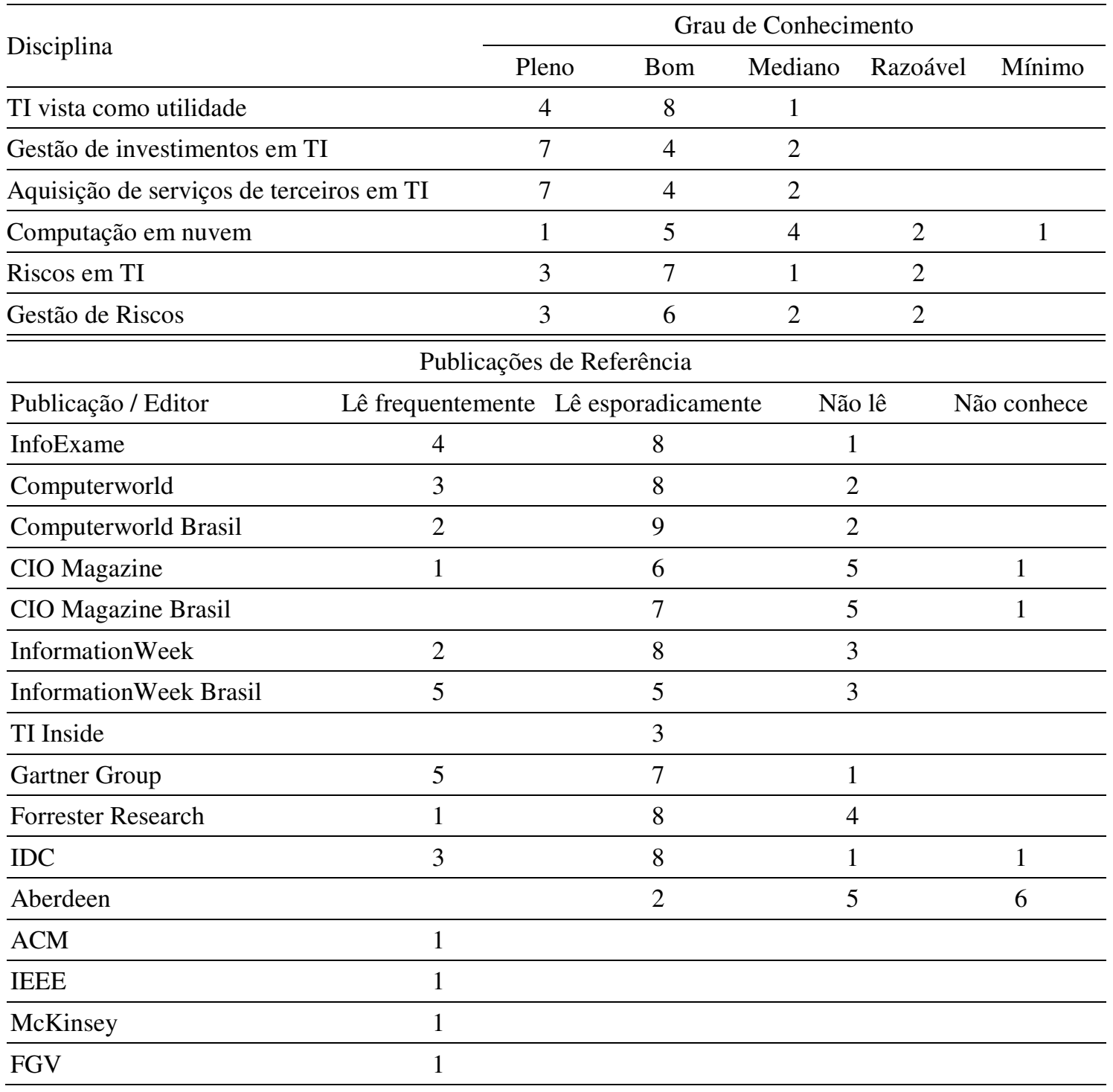




\section{Apêndice 4 - Variáveis e Fórmulas de Cálculo Relativas ao Painel Delphi}

\begin{tabular}{|c|c|c|}
\hline & Variável / Definição & Fórmula \\
\hline $\operatorname{rank}_{k j}$ & $\begin{array}{l}\text { Peso atribuído a uma posição ocupada por um elemento } \\
k \text { numa lista ordenada } j\end{array}$ & \\
\hline$R_{k}$ & $\begin{array}{l}\text { Soma dos ranks de um elemento } k \text { em } j \text { listas ordenadas } \\
\text { elaboradas num tema de um painel; indica a posição do } \\
\text { elemento na lista ordenada coletiva }\end{array}$ & $R_{k}=\sum_{j} \operatorname{rank}_{k j}$ \\
\hline$n$ & Quantidade de elementos em uma lista ordenada & \\
\hline$m$ & $\begin{array}{l}\text { Quantidade de listas individuais ordenadas elaboradas } \\
\text { num tema de um painel }\end{array}$ & \\
\hline $\bar{x}$ & $\begin{array}{l}\text { Média da soma dos ranks do total de elementos de um } \\
\text { conjunto de listas ordenadas elaboradas num tema de } \\
\text { um painel }\end{array}$ & $\bar{x}=m(n+1) / 2$ \\
\hline$X_{k}$ & $\begin{array}{l}\text { Diferença entre a soma dos ranks de um elemento } k \text { e a } \\
\text { média }\end{array}$ & $X_{k}=R_{k}-\bar{x}$ \\
\hline$Y_{k}$ & $\begin{array}{l}\text { Quadrado da diferença entre a soma dos ranks de um } \\
\text { elemento } k \text { e a média }\end{array}$ & $Y_{k}=X_{k}^{2}$ \\
\hline$S$ & $\begin{array}{l}\text { Soma dos quadrados das diferenças entre a soma dos } \\
\text { ranks de um elemento } k \text { e a média }\end{array}$ & $S=\sum_{k} Y_{k}$ \\
\hline$t_{i j}$ & $\begin{array}{l}\text { Quantidade de elementos no } i \text {-ésimo grupo de empates } \\
\text { numa lista ordenada } j\end{array}$ & \\
\hline$T_{j}$ & $\begin{array}{l}\text { Fator de ajuste relativo ao total de empates numa lista } \\
\text { ordenada } j\end{array}$ & $T_{j}=\sum_{i}\left(t_{i j}^{3}-t_{i j}\right) / 12$ \\
\hline$W$ & $\begin{array}{l}\text { Coeficiente de concordância (quando não há empates, a } \\
\text { última parcela é suprimida, pois é igual a 0) }\end{array}$ & $W=S /\left(\left(n^{3}-n\right) m^{2} / 12-m \sum_{j} T_{j}\right)$ \\
\hline$\chi^{2}$ & $\begin{array}{l}\text { Chi-quadrado, com }(n-1) \text { graus de liberdade, utilizado } \\
\text { para avaliar a significância de } W\end{array}$ & $\chi^{2}=m(n-1) W$ \\
\hline
\end{tabular}

